American University Washington College of Law

Digital Commons @ American University Washington College of

Law

Articles in Law Reviews \& Other Academic Journals

Scholarship \& Research

2004

\title{
Whose Music is it Anyway? How We Came to View Musical Expression as a Form of Property
}

\author{
Michael W. Carroll \\ American University Washington College of Law, mcarroll@wcl.american.edu
}

Follow this and additional works at: https://digitalcommons.wcl.american.edu/facsch_lawrev

Part of the Entertainment, Arts, and Sports Law Commons, Intellectual Property Law Commons, Internet Law Commons, and the Legal History Commons

\section{Recommended Citation}

Carroll, Michael W., "Whose Music is it Anyway? How We Came to View Musical Expression as a Form of Property" (2004). Articles in Law Reviews \& Other Academic Journals. 1204.

https://digitalcommons.wcl.american.edu/facsch_lawrev/1204

This Article is brought to you for free and open access by the Scholarship \& Research at Digital Commons @ American University Washington College of Law. It has been accepted for inclusion in Articles in Law Reviews \& Other Academic Journals by an authorized administrator of Digital Commons @ American University Washington College of Law. For more information, please contact kclay@wcl.american.edu. 


\section{Working Paper Series}

\section{Whose Music Is It Anyway?: How We Came To View Musical Expression As A Form Of Property - Part I \\ Michael W. Carroll \\ Villanova University School of Law, mcarroll@wcl.american.edu}




\title{
WHOSE MUSIC IS IT ANYWAY?: HOW WE CAME TO VIEW MUSICAL EXPRESSION AS A FORM OF PROPERTY
}

\author{
Michael W. Carroll
}

\section{INTRODUCTION}

The year 2003 marked the end of the first decade of the "digital revolution." 1 Of the many changes wrought by developments in digital

* Assistant Professor of Law, Villanova University School of Law. Thanks to Oren Bracha, Douglas Galbi, Jacqueline Lipton, Jessica Litman, and Michael Madison for insightful comments. I also received helpful comments on oral presentations of this Article at the Cyberlaw Retreat convened by Harvard Law School's Berkman Center for Internet and Society and at the June 2003 Law and Society Annual Meeting. I thank the participants in both fora for their thoughts. The Villanova community has done much to support this project. For helpful and supportive comments, I thank my colleagues Michelle Anderson, Leslie Book, Ann Juliano, Greg Magarian, and Michele Pistone. For enthusiastic research assistance, I thank Christopher Nickels and Elizabeth Pulbratek; for unswerving administrative support, I thank Joan Delong; and for cheerful and efficient processing of numerous inter-library loan requests, I thank the reference librarians at the Villanova University School of Law. Finally, I gratefully acknowledge Villanova University School of Law's financial support for this research. As ever, my family has been a source of inspiration and support, and I thank Kristy, Madeleine, and Vivian Carroll for that.

1. The technology underlying the explosive growth of the Internet certainly is far older than a decade. Digital technology dates back to the 1930s, computing technology dates back to the 1940s (unless one wants to count the abacus), and much of the research on packet-switched digital networks began in the early 1960s. See, e.g., John NAUGHTON, A Brief History OF THE Future: The Origins of THE INTERNET 92, 118-19 (1999); see also LeOnard KLeinrock, Communication Nets: Stochastic Message Flow and Delay (1964). But 1993 approximates the time at which those outside the computing community began to get wind of the Internet and the future that it might portend.

In September 1993, the Commerce Department released its "Agenda for Action" for the "National Information Infrastructure," heralding the new technology in glowing terms. Administration Policy Statement, 58 Fed. Reg. 49,025 (Sept. 21, 1993); see also John Perry Barlow, A Declaration of Independence for Cyberspace, in Crypto Anarchy, Cyberstates And Pirate Utopias 27 (Peter Ludlow ed., 2001). In that same year, the first issue of Wired magazine, devoted to the brave new wired world, hit the newsstands. Since then, expansion of the physical infrastructure, supported by adoption of open technical standards, has indeed led to some substantial changes in how we communicate. Significant portions of business communication and the personal communications of the upper and middle classes in the United States are channeled across the packet-switched network as electronic mail or instant messages. See, e.g., Ariana Eunjung Cha, Digital Divide'Less Clear, As Internet Use Spreads, Policy Debated Anew, WASH. POST, June 29, 2002, at E1 (reporting on study showing that less than half of the residents of the United States with incomes between $\$ 15,000$ and $\$ 25,000$ have Internet access at home or at work, compared to the $90 \%$ of residents with incomes of more than $\$ 75,000$ ).

Two developments in particular threaten revolution. The first development has been the digitization of the sights and sounds (and smells?)—the texts—that make up our popular culture. See, e.g., Michael W. Carroll, Disruptive Technology and Common Law Lawmaking: A Brief Analysis of A\&M Records, Inc. v. Napster, Inc., 9 VILL. SPORTS \& ENT. L.J. 5 (2002) (describing process by which popular music has been digitized). The second has been the deployment of digital networks featuring an architecture that disperses control and power over communication largely to end users of the network. Exploiting these developments, manufacturers of socalled "peer-to-peer" software have enabled end users to form virtual private networks through which each end user's machine is a "peer" with all other machines insofar as the machine is both a "client," which requests data, and a "server," which sends data. Users of these networks serve and receive digital renderings of sight and 
technology, one of the most hotly contested has been the legal and social status of music. In 2000, the stunning growth of Napster's network, which enabled users to "share" music files across the Internet with a few million of their closest friends, brought this still-unresolved controversy to prominence. $^{2}$ Ever more promiscuous transmissions of music files across the Internet have drawn an enraged response from music publishers, recording companies, and some recording artists and composers, who collectively characterize the millions of Internet users who engage in the unauthorized exchange of prerecorded music across the Internet as "thieves." This charge has been laid in lawsuits, news reports, advertising, and at the Grammy Awards. In April 2003, representatives of the Recording Industry of America Association (RIAA) sent the following instant message to thousands of users of the Kazaa peer-to-peer network: "When you break the law, you risk legal penalties. There is a simple way to avoid that risk: DON'T STEAL MUSIC." 3

Necessarily undergirding the charge of theft is the premise that music is a form of property — an odd kind of property that can be "stolen" by unauthorized reproduction and distribution. Among the millions of Internet users exchanging music files, some agree that they are in effect engaged in looting. ${ }^{4}$ Many, however, deny the charge. Some declare that "information wants to be free" and that music, like all other forms of digitized cultural expression, no longer can be or should be treated as

sound in open disregard for traditional channels through which works of popular culture have been purveyed and in open disregard of copyright law, which has underwritten the traditional arrangements for selling pop culture. The size of peer-to-peer networks continues to grow. For example, Napster's most popular successor, the Kazaa Media Desktop, reportedly now has become the most downloaded piece of software in Internet history. See Most Downloaded Program on the Web?, available at http://www.cnn.com/2003/TECH/internet/05/23/media.kazaa.reut/ (last visited Feb. 1, 2004).

2. See, e.g., A \& M Records, Inc. v. Napster, Inc., 239 F.3d 1004 (9th Cir. 2001) (holding Napster liable for users' unauthorized transmissions of music files). For a detailed look inside the business side of Napster's meteoric rise, see Joseph Menn, All the Rave: The Rise and Fall of SHawn Fanning's Napster (2003). For more on the technology and specific copyright issues raised by Napster, see generally Carroll, supra note 1 (describing process by which popular music has been digitized).

3. See Amy Harmon, Music Industry Sends a Message to PC Screens: Sharing Is Theft, N.Y. TimES, Apr. 30, 2003, at C1 (quoting instant message sent by representatives of the Recording Industry of America Association to users of the Kazaa file-sharing network). Escalating this conflict, the RIAA recently has won the right to unmask the online identities of those who transfer music files across peer-to-peer computer networks. With that information, the RIAA has commenced a campaign against individuals alleged to have engaged in large-scale unauthorized transmissions of music files. See, e.g., Amy Harmon, 261 Lawsuits Filed on Music Sharing, N.Y. TIMES, Sept. 9, 2003, at A1 (describing lawsuits as the "first broad legal action aimed at ordinary users of file-sharing networks").

4. To further bolster support for the view that unauthorized file swapping is theft per se, the RIAA has offered amnesty to those file traders willing to publicly confess to theft. See, e.g., Andy Sullivan, Repent Downloaders and Get Amnesty, Reuters, Sept. 5, 2003, available at http://www.reuters.com/newsArticle.jhtml;? storyID=3396175. 
proprietary information. ${ }^{5}$ Others accept the premise that music is a form of property but deny that their activities infringe the rights of property owners. A third view looks at music as a form of shared property. On this view, creators have some rights to control the initial sale and distribution of music, but buyers also have rights to use and "share" the music they have purchased. ${ }^{6}$

This conceptual conflict over music's status has been brought into relief by changed material circumstances. Finding a resolution to this conflict and reflecting that resolution in law are fundamentally challenging issues for our society. As part of a larger project to address these issues, this Article proceeds from the premise that a better understanding of how and when proprietary concepts came to be applied to music will aid the effort to find a resolution to the current conflict over digital music. Most readers likely have an intuitive sense that people have produced music without copyright protection for a long period of time. That intuitive sense is correct, but a more detailed understanding of how and why those in the West came to treat musical expression as a form of property is necessary to evaluate whether those reasons remain persuasive. ${ }^{7}$ The bulk of what follows is a survey of the relevant historical literature to trace how and when in Western history music came to be the subject of proprietary

5. In one of the opening shots of the revolution, John Perry Barlow predicted that digitization would prove an insurmountable challenge to the effectiveness of the copyright law. See John Perry Barlow, Selling Wine Without Bottles: The Economy of Mind on the Global Net, WIRED, March 1994, at 84 ("Intellectual property law cannot be patched, retrofitted, or expanded to contain the gasses of digitized expression.").

A decade after Barlow issued his challenge, another Internet visionary, William Gibson, has predicted that digital technology and the Internet spell the end of the big lottery-like payouts for successful musicians: Prior to the technology of audio recording, there was relatively little one could do to make serious money with music. Musicians could perform for money, and the printing press had given rise to an industry in sheet music, but great fame, and wealth, tended to be a matter of patronage. The medium of the commercial audio recording changed that, and created industry predicated on an inherent technological monopoly of the means of production. Ordinary citizens could neither make nor manufacture audio recordings. That monopoly has now ended. Some futurists, looking at the individual musician's role in the realm of the digital, have suggested that we are in fact heading for a new version of the previous situation, one in which patronage (likely corporate, and non-profit) will eventually become a musician's only potential ticket to relative fame and wealth. The window, then, in which one could become the Beatles, occupy that sort of market position, is seen to have been technologically determined. And technologically finite. The means of production, reproduction and distribution of recorded music, are today entirely digital, and thus are in the hands of whoever might desire them.

William Gibson, speech given to the Director's Guild of America's Digital Day, May 17, 2003, available at http://www.williamgibsonbooks.com/archive/2003_05_01_archive.asp\#200322.

6. This last view is perhaps the most intriguing because it forces a confrontation over how rights in the intangible musical work and the media in which it is carried are to be shared.

7. See Peter Drahos, A Philosophy of Intellectual Property 13 (1996) ("History also matters to an economic or consequentialist analysis of intellectual property .... For such approaches, the real data of history would be a preferred source for understanding the effects of intellectual property rather than a priori theory."). 
claims vindicated by law. The focus is threefold: to understand how those in the past conceived music's social role; to understand how music production and distribution were financed prior to the invention of copyright; and to consider the relationship between changed material conditions and the social conception of music. ${ }^{8}$

Part II supplies the theoretical and methodological framework for the historical inquiry. The relevant policy question that the conflict over digital music poses is whether we should continue to treat music rather than all copyrighted works as the subject of exclusive rights. From this perspective, copyright is a tool to facilitate musical production and its utility in that regard should be addressed with a focus on music production and distribution rather than a focus on copyright per se. Part II also addresses how "music" is defined and discusses what criteria are used in this Article for assessing when music came to be treated as a form of property.

Part III shows that musicians did not make proprietary claims in relation to music for most of the history of Western Europe, from classical Greece to the end of the sixteenth century. ${ }^{9}$ Even though trade in books began during ancient Greece and has continued, with periodic interruptions, until the present, ${ }^{10}$ and even though the Greeks established a system of musical notation, music remained part of an exclusively oral tradition until well into the Middle Ages. In addition, although musical labor has been a

8. Modern copyright law rests primarily on an economic justification — that property-like rights create incentives for investments in production and distribution of music — but some also justify copyright with natural law theories by which the act of intellectual labor gives rise to property rights, or should be rewarded with property rights as a matter of moral desert. In conducting the research, I also asked a series of questions in light of both justifications for treating music as property. As to natural rights claims, I asked when did composers, performers, and/or those who financed composition or performance come to make proprietary claims over music, and at what point did law vindicate those claims? As to the utilitarian justification, I asked: (1) since when has society valued music production enough to support professional composers and performers; (2) how has a division of labor that features specialized composers and performers been financed; and (3) at what points were property rights and resultant markets chosen as the predominant means for financing the production and distribution of music? A third line of inquiry has involved law's treatment of music as a form of expression. As the U.S. Supreme Court has recognized, under U.S. law musical expression is protected from some government regulation by the First Amendment. That has not been the view of regulators throughout history, and the record reflects censorship of musical expression on a variety of occasions. I asked when and how the state or political authorities have acted to censor or otherwise regulate the content of musical expression.

9. The selection and arrangement of the period studied risks further reifying "Western Civilization" as an object of study, an object which tends to be aristocratic in focus and which tends to discount the contributions and influences of the peoples originating in many other parts of the world. My reason for following the well-trod path of aristocratic eurocentrism is that modern American copyright law traces its roots to the legal and social structures of the publishing industry in England, with some influence from the continent, dating to the Late Middle Ages/Early Renaissance. The authors and composers of that period claimed an intellectual ancestry they traced back to Classical Greece. Focusing on the sources that influenced the development of modern property notions related to music is the purpose of this study.

10. See infra notes $252,278-79,303,342-43$ and accompanying text. 
feature of human existence from the earliest of times, composers made proprietary claims to their compositions only episodically during the latter Middle Ages, and consistently only during the Renaissance with the advent of music publishing. In the ancient world and in medieval Europe, music was thought to be divinely inspired, and it circulated as a form of background knowledge stored in the minds of performers and audience.

During the Renaissance, the creation of printed music gave rise to proprietary claims over these musical objects by publishers and, in rare cases, composers. These claims received legal vindication in the form of the printing privilege, a royal grant of exclusive rights to use a particular printing technology or process, or to publish specific classes of works or individual works. ${ }^{11}$ Under these legal arrangements, the property was the profits from the distribution of printed music, and that property belonged to the publishers, who frequently made risky and substantial investments in bringing printed music to market. ${ }^{12}$ This Article highlights one prominent exception - the case of Flemish composer Orlando Lassus (di Lasso)—who, in his capacity as composer, successfully petitioned the French and Burgundian monarchs for the privilege to print his entire repertoire. Because legal scholarship has focused on the rights of literary authors,

11. See infra Part III.C.2.a (describing operation of privilege system).

12. Conceptually, the exclusive right was a means of securing the property interest in the profits, and for that reason the right to print music was almost always assigned to publishers. The Renaissance conception of exclusive rights in music differed from modern copyright in a number of respects. Most prominently, the privilege secured the exclusive right only to profits flowing from the sale of music in the printed form rather than all profits associated with exploitation of musical compositions. The development of copyright reflects conceptual development on two different fronts regarding the subject of the exclusive rights. As Oren Bracha argues, the expansive modern concept of the intangible work that copyright protects would not be developed until much later. See generally Oren Bracha, Owing Ideas: The History of Anglo-American Intellectual Property Law (unpublished dissertation on file with author). For this reason, it would not be until the latter nineteenth century that profits from public performance would become the property of copyright owners.

More fundamentally, the conceptual disagreement focuses on whether the rights to exclude are only to profits from exploitation of the protected object, however defined, or whether the rights attach to the object itself. On the former understanding, any non-commercial use of music that does not interfere with the publisher's profit would fall outside the scope of the rights. Cf. LYMAN RAY PATTERSON, COPYRIGHT IN Historical PERSPECTIVE 215 (1968) (contrasting copyright's early function to protection only against piracy of profits with latter function to protect content from plagiarism). What might be contested is whether all profits or potential profits fall within the rights and whether the rights apply when a rightsholder seeks to expand her market by charging a license fee for an otherwise non-commercial use. ASCAP's demand for payment of a performance license from the Girl Scouts for singing campfire songs would be an example. See, e.g., John Zittrain, Calling Off the Copyright War: In Battle Between Copyright vs. Free Speech, No One Wins, Boston GloBE, Nov. 24, 2002, available at http://cyber.law.harvard.edu/is03/ Readings/Zittrain_1.pdf. On the view that the rights attach to the intangible object itself, any unauthorized use of the work would presumptively violate the exclusive rights unless some public policy imposed a limitation on the rights in the object. See id. (discussing modern publishers' perspective of copyright). Modern fair use jurisprudence demonstrates that this conceptual conflict remains alive and well. 
most histories of copyright do not recognize the Lassus case as a precursor to legal grants of rights to authors. ${ }^{13}$

Insofar as the social role of professional musicians is concerned, society appears to have valued the benefits from having specialized, professional musicians and has thus found a variety of means to support and finance their specialized labor, including slavery, patronage, and market relations. For most of the period covered in this study, musicians were performers first and composers, if at all, second. The roles began to change during the Renaissance when certain ruling elites had sufficient demand for new ceremonial compositions to support specialized composers. The information presented indicates that even if the Internet were to fatally undermine the profitability of distributing recorded music, we are likely to find ways to financially sustain a class of professional composers and performers. The challenge for our society is to evaluate whether copyright law remains the best means of doing so.

Part IV summarizes the findings and, subject to a principle of hermeneutic humility, draws some lessons from history for those engaged in the current debate over the future of music. We find that in societies without musical objects, control over musical labor - through slavery, patronage, or guild restrictions-was in some respects control over music itself. Music publishing and the growth of mercantile society changed the focus of control from control over musicians' mental texts to printed, tangible texts. The tangibility of printed music made property rights claims in the represented intangible work more easily conceivable and palatable. The "property" rights in these texts owned by composers and publishers largely were, as a practical matter, viewed as rights against competitors.

Lessons we can learn from this history include the need to understand how to respond to changed material conditions. Ancient peoples had the materials necessary to commodify music but embraced a conception of music antithetical to such commodification. They did not ask whether changed conditions - the arrival of papyrus and development of musical notation, for example-made other conceptions of music possible and relatively more desirable. We can and should analyze how digital technology enables new conceptions of musical expression. ${ }^{14}$ Proprietary concepts were extended to printed music in response to specific economic conditions, which have changed dramatically over time. Digital technology has changed, or can change, the economics of music production and distribution. Because economic considerations supply the justification for copyright law in the United States, changed economic conditions should

13. Lasso's conception of his entire musical corpus as being the source of, and reflective of, his persona anticipates the author's rights view of copyright.

14. See infra Part IV.B 
lead policymakers to re-examine the scope and content of copyright law as applied to music. Finally, the history shows that musicians throughout the period discussed in this Article freely borrowed from existing musical works when creating new works. Digital technology facilitates such borrowing, in music samples or mash-ups, for example. Modern copyright rules that greatly restrict musicians' freedom to practice this tradition rest on questionable justifications and likely require revision. ${ }^{15}$

By engaging in this inquiry, this Article accomplishes three goals. First, it recontextualizes the current controversy surrounding the propriety of the unauthorized exchange of music files on the Internet. The relevant question is what normative vision of music's role in society copyright law should promote, rather than simply whether we should destroy, save, or modify copyright law writ large. By reviewing the early history of music's role in Western society, I show how the view that music is proprietary information began to form in response to technological, economic, and social change. This change has not uniformly affected creative expression, and over time music has been treated differently in some respects from literary expression, visual art, and other creative works. Moreover, we learn that neither a purely materialist nor idealist account can explain how we came to view music as a form of property. Both of these perspectives must be combined to understand the past, and this hybrid perspective opens new understanding for our possible future.

Second, the evidence shows that many of the claims about the sanctity of musical property are overstated. The property-rights model for music has had a profound influence on the financing of musical production and distribution, beginning in the late fifteenth century and intensifying in the twentieth century. But people have been making music throughout recorded history. More importantly, throughout most of this period society has valued the services of professional musicians enough to financially support such a group without reliance on property rights in music. Removing copyright protection from musical works and sound recordings would not eliminate professional musicmaking. On the contrary, historical evidence strongly suggests that demand for the services of a class of professional musicians and composers would be sufficient to induce society to find alternative means to enable this group to practice its art. But we have good reason to think that the amount of music and the quality of music produced would be different from that produced under

15. Public Pressure has begun to force such change. See, e.g., Bill Werde, Defiant Downloads Rise From the Underground, N.Y. TimES, Feb. 25, 2004, at E3 (describing "Grey Tuesday" during which multiple web sites responded to a claim of copyright infringement against a Los Angeles D.J. by offering for free download his work, “The Grey Album," featuring rapper Jay Z's a cappella raps form his “The Black Album” mixed over music tracks taken, and often substantially transformed, from the Beatles" "The White Album"). 
our current system. Consequently, the history demonstrates that arguments about whether to save or reform copyright in music must center on copyright's relative ability to encourage the production of music and to finance the livelihoods of specialized musicians.

Finally, this Article fills a substantial gap in the legal history of copyright law. Copyright history generally has focused on the legal treatment of books and has ignored or subordinated the history of music. ${ }^{16}$ This Article shows how music is a different kind of expression than literature, and it shows some ways music has been treated differently from other forms of intellectual expression throughout much of our history.

\section{THEORETICAL FRAMEWORK AND METHODOLOGY}

Some preliminary remarks on the theoretical and normative framework behind this study will help the reader better digest the details presented in Part III. This short section discusses my understanding of the relevant policy questions that must be answered to resolve the current conflict over digital music and provides a brief description of the object in this study, "music," as well as what it means to treat music as a form of property.

\section{A. Music Policy in the United States}

Most legal scholars and many in the entertainment industry view the conflicting claims over digital music as reflecting a broader controversy concerning the role that copyright law should play in the digital age. On this view, music simply is the test case. ${ }^{17}$ From this perspective, digital technology poses three sets of challenges or opportunities - depending on one's perspective-for copyright owners and users. The challenges/opportunities are: (1) those created by the limits of current technology and law for copyright owners to effectively control distribution of copyrighted works via distributed computing (as in peer-to-peer networks); ${ }^{18}$ (2) those created by reduced production and distribution

16. See, e.g., MARk Rose, Authors ANd OWners: THe InVENTION OF Copyright (1993); LyMAN RAY Patterson, Copyright in Historical Perspective 63-74 (1968); Benjamin Kaplan, An Unhurried View of Copyright (1968); Harry Hundt Ransom, The First Copyright STAtute: AN Essay on $A N$ ACT FOR THE ENCOURAGEMENT OF LEARNING 1710 (1956).

17. See, e.g., National Research Council, The Digital Dilemma 76-95 (2000) (treating music as intellectual property's "[c]anary in the [d]igital [c]oal [m]ine").

18. From music copyright owners' perspective, this is a challenge because they have reduced ability to obtain revenue from distribution of their music, and, for that very reason, the technology presents listeners with the opportunity to obtain copies of a broad range of music at low cost. 
costs; ${ }^{19}$ and (3) those posed by the potentially greater control than the law permits afforded by digital rights management technologies. ${ }^{20}$

The dominant view assumes that any industry-specific variations in the effects of digital technology are differences in degree rather than kind. On this view, the policy question posed by the new challenges or opportunities is what role copyright law should play in the digital age rather than whether copyright's utility as a policy tool should be judged in relation to particular forms of expression. This view of the appropriate policy question is held even by some who believe that the changed economics of production and distribution should lead to radical change. ${ }^{21}$

This Article proceeds from a different premise. The relevant question is not what copyright policy should be but rather what music policy should be in the United States. ${ }^{22}$ Copyright law is a tool by which music policy may be implemented, but it is not the only tool. My claim is that the changes to music production and distribution made possible by digital technology coupled with the heated social debate concerning ownership and control over musical expression are sufficiently disruptive that we should revisit what music policy in the United States is and should be. From a utilitarian perspective, we should be open to the possibility that copyright no longer is the best tool for stimulating musical innovation, even if copyright law remains cost-justified for more expensive forms of expression, such as feature films. The history and structure of modern copyright support different treatment, as copyright protection was extended to music later than to other forms of expression and modern copyright law already has a number of industry-specific provisions, ${ }^{23}$ many of which apply to musical expression. ${ }^{24}$ Even if we conclude that copyright remains a useful tool for stimulating music production and distribution, as is likely, attention to what music policy should be will likely

19. Reduced costs increase the size of the surplus to be had from transactions involving recorded music. The challenge and opportunity for copyright owners and listeners is how this new marginal surplus will be distributed either in the form of increased profits or lower prices.

20. From the copyright owners' perspective, digital rights management presents the opportunity to increase the rents to be had from music distribution, and, for that very reason, presents listeners with the challenge of preserving traditional fair use rights.

21. See Raymond Shih Ray Ku, The Creative Destruction of Copyright: Napster and the New Economics of Digital Technology, 69 U. CHI. L. REV. 263 (2002).

22. The reader may find the notion of "music policy" in the United States to be misplaced or at least too European. That only is because once a form of expression has joined the copyright club, we generally have not discussed revoking membership (i.e., disaggregating rights) or even creating tiers of membership based on industry-specific economic factors. This resistance does not alter the fact that the combination of copyright law, communications law, and the First Amendment as applied to music comprises U.S. music policy.

23. See, e.g., 17 U.S.C. IS 111-122 (2000).

24. See, e.g., Michael W. Carroll, A Primer on U.S. Intellectual Property Rights Applicable to Music Information Retrieval Systems, 2003 U. ILL. J.L. TECH. \& POL’Y 313 (describing basic structure of music copyright). 
lead to recognition that copyright in music needs further revision to adapt to the changed material conditions of today and tomorrow.

As is true of most copyrightable expression, music fits into the legal paradigm of free speech as well. Throughout history, music has been the medium for wide-ranging communication, whether it has been solely instrumental music or music coupled with poetry. ${ }^{25}$ Music helps define our experiences and encode our memories, and its domain encompasses nearly all facets of our lives, including those of religion, culture, and politics. ${ }^{26}$ Because music has the power to create and communicate social meaning, political leaders have sought to regulate it throughout much of history. The dangers posed by direct governmental regulation of music have led us to adopt a music policy that greatly constrains such regulation. In the words of the United States Supreme Court:

Music is one of the oldest forms of human expression. From Plato's discourse in the Republic to the totalitarian state in our own times, rulers have known its capacity to appeal to the intellect and to the emotions, and have censored musical compositions to serve the needs of the state .... The Constitution prohibits any like attempts in our own legal order. Music, as a form of expression and communication, is protected under the First Amendment. ${ }^{27}$

25. No shortage of speculation surrounds the origins of music. See, e.g., Marius Schneider, Primitive Music, in 1 The New OXford History of Music: AnCIENT AND Oriental Music 1, 5-6 (Egon Wellesz ed., 1957) [hereinafter 1 NEW OXFORD HISTORY] (reporting that Charles Darwin suggested that earliest song imitated animal mating cries, while Rousseau, Herder, and Spencer traced song to a stylized form of speech); CURT SACHS, The Rise of Music IN THE ANCIENT World: EAST AND West 19-20 (1943) (rehearsing thencontemporary theories of music's origin); see also JACQUES CHAILLEY, 40,000 YEARS OF MUSIC: MAN IN SEARCH OF MUSIC 61 (Rollo Myers trans., 1964) (stating that archaeological evidence suggests that hominids have been using instruments for the production of sound for at least 40,000 years).

26. For this reason, music also serves as the source for rich metaphor applicable to other domains, including law. See generally Carol Weisbrod, Fusion Folk: A Comment on Law and Music, 20 CARDOZO L. REv. 1439 (1999).

27. Ward v. Rock Against Racism, 491 U.S. 781, 790 (1989). For those not fully in the thrall of the public-private distinction, the First Amendment may not be as robust a tool against musical censorship as Justice Kennedy implies. When Natalie Maines, singer for the Dixie Chicks, made a disparaging remark about President George W. Bush at a London concert, some radio stations owned by the largest corporation that owns radio stations in the United States reduced air time given to the band's very popular CD. See, e.g., Mary Mitchell, Editorial, It's Clear Here That Media Monopolies Don't Serve Us, CHI. Sun-TIMES, June 8, 2003, at A14 (stating that some ClearChannel stations banned Dixie Chicks from airplay although ClearChannel executives deny conspiracy); Alisa Solomon, The Big Chill, THE NATION, June 2, 2003, at 17 ("Who needs government censorship when stations owned by Clear Channel, the nation's largest radio chain (reaching, thanks to deregulation, 54 percent of all American adults under age 49), can drop the Dixie Chicks from their playlists, as they did in March?”); see also Patriotism Lifts Pro-W ar Songs; Chicks Suffer, BILlBOARD, Apr. 5, 2003, at 1 (providing airplay and CD sales statistics for Dixie Chicks). Two country music disc jockeys in Colorado subsequently were suspended for violating their station's ban on Dixie Chicks' music. See G. Brown, With War Over, Dixie Chicks Are Back On Top, DenVer Post, May 15, 2003, at F1 (describing suspension). It should be noted that many country music fans were angered by Maines' statement, and one reason for the stations' ban was to respond to this sentiment. See id. (describing reaction of country music fans). 
Nothing in the current controversy calls into question music's status as a form of "speech"-rather, the policy questions are whether that speech requires subsidies from the government and how "free" from government regulation that speech should be. ${ }^{28}$ How can our treatment of music as protected speech be squared with extensive government regulation of music as a form of property through copyright law? The Court reminds us that copyright was adopted as "the engine of free expression." $29 \mathrm{By}$ regulating music as property, we facilitate the development of markets from which creators and distributors can fund their livelihoods. This understanding of copyright in music relies on economic understandings that digital technology challenges. Copyright law benefits composers and performers insofar as it supports the markets that provide revenue for creativity, but these markets also confine creativity in significant ways. Composers of popular music find themselves forced to tailor their work to fit within the narrowly-drawn genres expressed in the Billboard charts, radio formats, or the categories established by music retailers such as WalMart. Online distribution and Internet radio offer creators less restrictive channels for reaching audiences, but copyright law, as currently written, constrains the growth of both these channels. ${ }^{30}$

Consequently, we must inquire whether copyright in music still serves the purposes for which it was designed. Are there cheaper means for financing the creation and distribution of new music that provide creators greater expressive freedom? To engage in that inquiry, we must first acknowledge precisely how complex and intricate the "engine" has become when applied to music. ${ }^{31}$ The complexity of music copyright suggests that we should have a clear understanding of how and why the engine was built the way it was before we decide whether to shut it down, fundamentally redesign it, or tinker with its operation.

Nonetheless, formal state control over who makes music and what music can be heard is far less pervasive today in the United States than has been the case throughout much of history. Music's status as a form of protected speech certainly has contributed to the current degree of freedom from governmental interference that musicians in the United States enjoy.

28. See generally LaWRENCE Lessig, FreE Culture (2004) (arguing that copyright law should be scaled back to facilitate free expression).

29. Harper \& Row, Publishers v. Nation Enters., Inc., 471 U.S. 539, 558 (1985); see also id. (By "establishing a marketable right to the use of one's expression, copyright supplies the economic incentive to create and disseminate ideas.").

30. See, e.g., 17 U.S.C. $\$ 106(6)$ (2000) (granting owner of sound recording a digital audio transmission right that puts Internet radio at a competitive disadvantage by requiring webcaster to pay license fees to both composers and record labels where broadcaster pays only composers).

31. See, e.g., 17 U.S.C. $\$ \$ 106,112,114,115,116$ (2000) (granting exclusive, property-like rights in musical works and sound recordings and establishing complex set of limitations, exceptions, and statutory licenses applicable to those rights). These provisions set forth the baseline entitlements over which a layer of equally complex contractual relations rests. 
By taking a panoramic view of the history leading up to the current controversy, I seek to create room in the discussion for cooler consideration of fundamental change. ${ }^{32}$ Historical evidence demonstrates that Western society has conceived of music's social role and the roles of those who create and perform music quite differently over time. Rather than assume that music is a form of property and that the only challenge is how to protect it against new threats posed by digital technology, we should acknowledge that other means of stimulating musical creativity are feasible and were successful under different material and cultural conditions.

By taking the long view, we see the dialectic relationship between the material conditions under which music was produced and distributed and the cultural conception attached to musicmaking. Recognizing this relationship should lead us to be open to the possibility that the change in our own material conditions brought about by digital technology is the kind of change that has led to cultural reconception in the past. My claim here is not that the concept of copyright in music has been rendered obsolete by technological advance. I will take up that question in future work. Rather, at this point I argue that only by sincerely questioning whether copyright is our best option for stimulating musical creativity in light of our new circumstances can we analyze our full range of policy choices, give them due consideration, and do what we can to see the best ones implemented. ${ }^{33}$

\section{B. When is "Music" Treated Like "Property"?}

Two further preliminary matters require attention before proceeding with the story: what is "music" and what does it mean to say that music is "treated as property"? Music has no intrinsic definition. It is a cultural category consisting of any sounds that those in a society or culture designate as "music" instead of "noise," along with any notation, recording, or other means of capturing or representing such sounds. What sounds count as music has been a contested issue throughout Western history and remains a contested issue in the industrialized world today. Most musical systems organize sound according to rules, and throughout

32. In a different context, Mark Tushnet has noted that "self-historicism is self-alienation or selfestrangement" which "probably ought to lead us to think about why we hold the views we do." Mark Tushnet, Self-Historicism, 38 TULSA L. REv. 771, 775 (2003). That is one of my goals. Another is to apply some historicist balm to the current controversy so as to reduce the rhetorical heat in the debate over musical copyright. See id. at 777 .

33. For an example of the kind of open-minded deliberation about copyright which I advocate, see Diane Leenheer Zimmerman, Authorship Without Ownership: Reconsidering Incentives in a Digital Age, 52 DePAUL L. REV. 1121 (2003). 
history some musicians have always bent, twisted, or ignored those rules. Beethoven, for example, became famous for doing so. During the period studied herein, the category of music generally grew broader as composers and musicians challenged the rules for permissible expression, broadening the range of pitches considered to be musical and forcing acceptance of polyphonic expression, in which more than one pitch is played or sung at the same time.

Determining how and when "music" has been treated as "property" also requires a sense of dynamism. Just as the category of "music" has been changing over time, so too has the concept of property-particularly when used to describe legally-protected exclusive rights in intangible expression.

Modern copyright law vindicates a composer's proprietary claims over a wide variety of uses of music, including written representations of music in notation form, as part of a dramatic or audiovisual work, and when embodied in a sound recording. ${ }^{34}$ The composer's rights can be infringed by unauthorized reproduction or distribution of written or recorded music, creation of musical works derived from the composer's work, and, significantly, public performance of the musical works. ${ }^{35}$ Moreover, since 1972 federal law has recognized the performers, producers, and sound engineers who create musical sound recordings as authors in their own right. ${ }^{36}$ They also have rights to control reproductions and distribution of copies. Most recently, sound recording copyright owners have a right to control public performance by digital audio transmission. ${ }^{37}$ Modern copyright law's treatment of musical expression as the subject of exclusive, property-like rights includes a number of limitations and exceptions. ${ }^{38}$

34. See 17 U.S.C. \102(a) ("Works of authorship include . . (2) musical works, including any accompanying words; (3) dramatic works, including any accompanying music ... (6) motion pictures and other audiovisual works; [and] (7) sound recordings...."); see also 17 U.S.C. \$101 (“'Sound recordings' are works that result from the fixation of a series of musical, spoken, or other sounds, but not including sounds accompanying a motion picture or other audiovisual work, regardless of the nature of the material objects, such as disks, tapes, or other phonorecords, in which they are embodied."); see generally Carroll, supra note 24 (providing further detail on rights applicable to digital uses of music).

35. See 17 U.S.C. $\$ 106$. Section 106 also gives the owner of a musical work copyright the exclusive right to display the work publicly, but this right has not had much significance to date. Theoretically, displays over the Internet of sheet music, tablature, or other representations of musical works could become more salient, although there is little indication that such a development is likely in the near future.

36. See Agee v. Paramount Comm., Inc., 59 F.3d 317, 322 (2d Cir. 1995) (discussing legislative history of sound recording amendment); Systems XIX, Inc. v. Parker, 30 F. Supp. 2d 1225, 1228 (N.D. Cal. 1998) (citing legislative history for the proposition that authorship of sound recording is likely to include creative contributions of performers and record producers).

37. 17 U.S.C. $\int \$ 106(6), 112,114$ (2000 \& Supp.); see generally R. Anthony Reese, Copyright and Internet Music Transmissions: Existing Law, Major Controversies, Possible Solutions, 55 U. Miami L. Rev. 237, 252 (2001) (discussing sound recording digital performance right, limitations on the right, and complications in administering and interpreting the scope of the right).

38. E.g., 17 U.S.C. $\int S$ 107, 109, 111, 112, 114, 115, 116, and 118. 
Music copyright owners elide or ignore these when they treat all unauthorized uses of music as "theft."

My aim is to find the earliest ancestors of the modern claimants of property in music and theft of that property. When, why, and how did producers or distributors of musical expression claim it to be "theirs" and when, why, and how did the law vindicate such claims? As my aim is to identify more general proprietary claims over music rather than copyright claims specifically, music itself, or at least the profit to be made from music, is treated as "property" for purposes of this Article when three conditions are met:

(1) those associated with the production or distribution claim a proprietary relationship with the music (i.e., as something that is "theirs" insofar as it "belongs" to them);

(2) those who make proprietary claims also claim a right to receive attribution in connection with the music or to prohibit or control the reproduction, distribution, or performance of "their" music by others; and

(3) these claims of control are recognized and vindicated by law. ${ }^{39}$

\section{Methodology}

This Article relies on secondary sources in the historical and musicological literature to identify how and when music came to be property. My questions largely are a lawyer's questions. Understandably, the available literature written by historians and musicologists does not focus on music's social status as reflected in law. Consequently, for the legal reader, the story told in Part III almost certainly will prompt some questions that this Article does not answer. For many of these questions, the primary source materials from which an answer might be drawn simply are not available. This particularly is true when one seeks to understand musical practices and musical understandings of non-elite members of society. Even when primary sources have been found, historians and musicologists often have not addressed the broader social or economic history of musicmaking and musical semiotics. Indeed, one of the current trends in musicology is to give social and economic history greater attention, and those interested in the legal and social status of music over time will undoubtedly benefit from such research.

39. This is a more limited definition than is associated with the modern version of the bundle of rights generally associated with rights in real property or even the more limited bundle under copyright. See, e.g., Michael A. Heller, The Tragedy of the Anticommons: Property in the Transition from Marx to Markets, 111 HARV. L. Rev. 621, 661-64 \& n.191 (1998). Specifically, a right to transfer the right to control is not a necessary condition for music to be regarded as a form of property. 


\section{The LEgAL AND SOCIAL StATUS OF MUSiC IN WESTERN History-ANCIENT GREECE THROUGH THE RENAISSANCE}

This section chronologically surveys how and when music came to be treated as a form of property in Western Europe. The inquiry focuses on when music's treatment as property gave the "owner" grounds to claim that the same or similar expression could not be produced or distributed and that the initial producer was entitled to attribution for the music.

Following the conventional divisions of Western history, this section consists of three parts: the ancient world, the Middle Ages, and the Renaissance. In ancient Greece and Rome, the preconditions for objectifying musical expression in written texts were present but were not used for that purpose. Instead music remained part of an oral tradition and was not commodified. During the Middle Ages, the tools for commodification-particularly musical notation-had to be reinvented. Musical texts likely to be the objects to which property rights apply were not in circulation until the latter portion of the period, and the social role of "the composer" as a potential claimant of property rights had only just begun to emerge. In the Renaissance, music publishing dramatically altered the landscape. Publishers received royal privileges with many copyright-like attributes and composers became self-aware subjects who potentially could be vested with property-like entitlements to their music.

\section{A. Ancient Greece and Rome}

The cultures of ancient Greece and Rome are relevant reference points for modern Americans because those societies each supported a leisure class, some of whose members engaged in thought and discourse on a wide range of topics and problems with which we remain engaged. Among those topics are theories of music ${ }^{40}$ and the role of music in society. Few direct sources have survived to teach us the music that was played; surviving scores (on papyrus and stone) are very fragmentary. ${ }^{41}$ Nonetheless, from poets and writers on the theory of music, we can piece together a framework for both the ideal and the real practice of music in ancient Greece.

40. Though interesting, ancient Greek music theory is not within the scope of this Article. For more on this theory, see SACHS, supra note 25, at 195-271.

41. See Lesley Adkins \& Roy A. Adkins, Handbook to Life in AnCient GreeCe 264-65 (1997); Thomas J. Mathiesen, Apollo's Lyre: Greek Music and Music TheOry in Antiquity and the MidDle AGES 12 (1999) (describing compositions in ancient Greek notation, of which "at least forty-five fragments ranging across seven centuries from the third century B.C.E. to the fourth century C.E. are now known.”). 
The absence of written music supplies a clue about the relationship between the material conditions under which music was produced and the cultural conceptions attached to musicmaking. We know that ancient Greeks had the tools for creating written music. They had developed musical notation, and papyrus eventually became available to support trade in written works after the fourth century B.C.E. ${ }^{42}$ At that point in time, libraries were assembled and commerce in books began to take root. ${ }^{43} \mathrm{But}$ music remained in the realm of intangible, collective expression. ${ }^{44}$ We can infer that the Greeks conceived of musical communication as having a different function and meaning than linguistic communication because much of the latter was preserved in writing while the former was not. ${ }^{45}$ Indeed, music was conceived of as an art taught by the gods, ${ }^{46}$ derived from intercession of the Muses. ${ }^{47}$

Although we cannot cite classical Greece as the source of proprietary claims in music or as the source of intellectual property law, ${ }^{48}$ two different aspects of Greek theory are particularly important for our story because they exerted significant influence over subsequent musical developments in a number of ways. The first is the notion that musical harmony reflects and is part of a larger set of mathematical, harmonic relations that governs

42. The absence of cheap and durable writing material is one reason we have so few texts from the early periods. See, e.g., Henri-JeAn MARTin, The History And Power of Writing 47 (Lydia G. Cochrane trans., 1994) (1988) (describing absence of paper and any ready substitutes); see also id. at 48 (describing subsequent development of export business in papyrus).

43. See id. (tracing commerce in books back to fifth century B.C.E.); Salathiel C. Masterson, Comment, Copyright: History and Development, 28 CAL. L. REV. 620, 621 (1940) (same).

44. Reflecting Romantic biases, as well as the complaints of some later Greek and Roman writers nostalgic for a Golden Age, some modern historians interpret the absence of written music and trade in such music as reflecting low status for the music during the fourth through second centuries B.C.E. See, e.g., Isobel Henderson, Ancient Greek. Music, in 1 New OXFORD History, supra note 25, at 336, 402 ("Musical illiteracy in an age of book-learning is a sure index of the decline in the status and quality of the art.").

45. Although musical and verbal expression appear to have been treated differently, the gap between the two was not as wide as it is in our modern-day print culture. Although elites engaged in written discourse, the oral tradition was far stronger than today. Within that tradition the musical qualities of the spoken word likely would have been far more salient than is generally appreciated in modern times. I thank Douglas Galbi for drawing attention to this point.

46. See Donald Jay Grout \& Claude V. Palisca, A History of Western Music 2-3 (6th ed. 2001) (asserting that Greek mythology ascribed to music a divine origin with early practitioners such as Apollo, Amphion, and Orpheus).

47. The word "music" is derived from Middle English musik, from Old French musique, from Latin musica, from Greek mousike, and originally referred to art presided over by the Muses. See WeBSTER's ThiRD NEW INTERNATIONAL DictionaRY 1490 (16th ed. 1971).

48. See, e.g., Bruce W. Bugbee, The Genesis of American Patent and Copyright Law 12 (1967) ("The legal safeguarding of rights in the products of creative thought was virtually ignored in ancient times."); Marianina Olcott, Ancient and Modern Notions of Plagiarism: A Study of Concepts of Intellectual Property in Classical Greece, 49 J. COPYRIGHT SOC’Y U.S.A. 1047, 1052 (2002) (surveying changes in plagiarism in classical Greece and concluding that most such charges were apocryphally laid by early Christian writers, although Aristophanes complained of having characters copied without permission). 
the physical and metaphysical universe. ${ }^{49}$ The second concept is that of music as an ethical discipline. The Greeks believed that music had the power to shape character. ${ }^{50}$ Although not as prevalent today, the ethical dimension of music still receives attention. ${ }^{51}$

The conceptual pre-conditions for proprietary claims made by individuals to specific usical works were missing in ancient Greece. Rather than view music as the product of human labor, music was a force of nature not susceptible to individual claims of ownership. The Greeks believed that embedded in the structure of music was the same rational, harmonic order that governed the cosmos. ${ }^{52}$ According to legend, Pythagoras, with divine guidance, discovered mathematical ratios underpinning musical harmony by observing the effects produced by different weights of hammers used by smiths. ${ }^{53}$ Most writers largely agreed that instrumental music revealed the harmonic order of the cosmos to the

49. See, e.g., Edward Lippman, A History of Western Musical Aesthetics 8 (1992) (“The harmony of the spheres is nothing less than a myth of Western civilization. It is found in the poetry and literature of every age, in innumerable commentaries on Plato, and in astronomical tracts.").

50. See id. at 10 (describing ethical views of music). Greek theory and practice also influenced groups of Renaissance composers and performers in the late fifteenth century, as well as those who invented opera around the turn of the seventeenth century. Greek theoretical texts, including the writings of Aristotle and Plato were (re)introduced into Italy in the fifteenth century, and their emphasis on the power of music led Renaissance composers on an ultimately fruitless journey to recreate the music of the ancient world. Additionally, Greek emphasis on the intimate relationship between music and lyric led Renaissance composers to pay much closer attention to this relationship as the madrigal form developed. Finally, the inventors of opera believed that Greek tragedy was sung, at least the parts of the chorus, and they sought to develop a musico-dramatic form that imitated ancient drama.

51. For example, modern commentator Allan Bloom describes the passion with which his undergraduate students debated the merits of Plato's strictures on musical expression. See Allan BloOm, The Closing of THE AMERICAN MIND 70 (1987) ("Students today ... know exactly why Plato takes music so seriously. They know it affects life very profoundly and are indignant because Plato seems to want to rob them of their most intimate pleasure."); see also id. at 73 (arguing for greater parental regulation of children's listening opportunities because "rock music has one appeal only, a barbaric appeal, to sexual desire—not love, not eros, but sexual desire undeveloped and untutored.").

52. See Grout \& PALisCA, supra note 46, at 5 ("[T] he system of musical sounds and rhythms, being ordered by numbers, exemplified the harmony of the cosmos and corresponded to it."). A more sophisticated version of cosmic harmony - string theory — is currently back in vogue among modern cosmologists. According to this theory, the fundamental elements of matter are vibrating strings rather than particles. For an accessible description of the theory, see NOVA: The Elegant Universe, available at http://www.pbs.org/ $\mathrm{wgbh} /$ nova/elegant/ (last visited Feb. 1, 2004).

53. See Music in the Western World: A History in Documents 3-6 (Piero Weiss \& Richard Taruskin eds. 1984) (introducing and reprinting tale from Nicomachus); GROUT \& PALISCA, supra note 46, at 7 (adapting the tale from Boethius, THE Fundamentals of Music Bk. I, ch. 10, p. 18 (Calvin M. Bower trans. 1989)); David L. Wagner, The Seven Liberal Arts and Classical Scholarship, in The Seven Liberal ARTS IN THE Middle Ages 3 (1983) [herinafter SEven Liberal ARTS]. He developed a set of ratios that, when applied to lengths of string on an instrument called a canon or monochord, permitted a mathematical description of the intonation for an entire musical system. See Lippman, supra note 49, at 5 (describing Pythagorean musical theory); MichaEL GRANT, THE CLASSICAL GREEKS 277 (1989) (describing inspiration from musical discovery to give mathematics a "universal status"). 
trained ear. ${ }^{54}$ Plato's writings reflect his appreciation for the generality of harmony, and his view that appreciation for relations between musical intervals could lead one to an understanding of the relations among the sciences. ${ }^{55}$ This concept of music as a scientific or mathematical discipline made music a necessary subject of study as part of what later would be called the quadrivium - i.e., the four mathematical liberal arts. ${ }^{56}$

\section{Music as an Ethical Discipline Necessitating Regulation}

Music in the United States today is sold as a commodity or as an experience. We recognize that music stimulates emotional responses, and we leave it to putatively sovereign consumers to choose, with the help of radio and other mass media marketing, music likely to stimulate a desired emotional response. Under the First Amendment, the government generally may not substitute its musical taste for that of consumers, although content labeling may be a permissible intervention to facilitate consumer choice.

The ancient Greeks had a radically different reaction to music's evocative power. In their view, while music's structure reflected balance and harmony, its effects could be quite powerful and disruptive of social order if left unregulated. ${ }^{57}$ In the views of influential writers, such as Plato and Aristotle, music's power to shape character and call forth powerful emotion necessitated regulation, with specific attention given to the need for compulsory musical education. ${ }^{58}$ Evidence shows that actual practice conformed, at least partially, with the views expressed by these writers. This regulation would have significant consequences for music production

54. See infra note 59 and accompanying text.

55. See Edward A. Lippman, Musical Thought in AnCient Greece 27 (1964) (asserting that Plato "appreciates fully the generality of harmony"). Plato, for example, relied on the Pythagorean ratios to describe in Timaens the structure of the soul of the universe and the human soul. See Lippman, supra note 49, at 5 (describing Timaeus). The view of music as microcosm attracted other mathematicians, such as Archytas, who further developed the mathematical understanding of musical expression. See Lippman, supra, at 6-18 (describing development of Pythagorean musical theory); GRANT, supra note 53, at 179 (describing Archytas' influence on Plato).

56. See LiPPMAN, supra note 49, at 6 ("Music was the most general of the [mathematical disciplines], permeating all the others and occupying a summary and culminating position.”); see also Wagner, supra note 53, at 1 (identifying the seven liberal arts of the Middle Ages as composed of the trivium—grammar, rhetoric, and logic or dialectic — and the quadrivium — arithmetic, music, geometry, and astronomy). Henderson complains that the study of music as a mathematical art should be understood as separate from the study of music as a practical art and that the conflation flows from semantic misunderstanding. See Henderson, supra note 44, at 336-403.

57. For Plato, "rhythm and harmony find their way into the inward places of the soul ... making the soul of him who is rightly educated graceful, or of him who is ill-educated ungraceful." PLATO, THE REPUBLIC of Plato: An Ideal Commonwealth 86 (Benjamin Jowett trans., Colonial Press 1901).

58. See GrANT, supra note 53, at 219 (stating that Plato thought state regulation of art, music and poetry was necessary to lead citizens to dictates of Reason rather than emotion); GROUT \& PALISCA, supra note 46, at 6-7 (describing Platonic and Aristotelian views on regulating music production and performance). 
and dissemination. On the one hand, the state's regulations would stimulate production by requiring musical education for the youth; on the other hand, the state would channel that demand by limiting the scope of permissible composition and instrumentation.

For Plato, the goal of education was to perfect the citizen's capacity for reason by learning to control and subjugate the emotions. Toward this end, musical instruction of the youth would be required. Musical instruction would be recursive: the young guardians of the ideal state would not become musical until they had an appreciation of the beauty of the cosmic order, and they would obtain such appreciation particularly through their education in the arts. ${ }^{59}$ (For Plato such training in harmonic relations also would yield a less litigious society. ${ }^{60}$ )

Plato also would have had the state thoroughly regulate all aspects of musical practice. With respect to music's content, simplicity must reign. ${ }^{61}$ Further, he would allow "only the lyre and the harp for use in the city, and the shepherds may have a pipe in the country." 62 He similarly ruled out complexity in lyrical meter and declared that instrumental music should conform to the poetry, not the other way around. ${ }^{63}$ Having constrained harmony, scale, and instrumentation, Plato also decreed that melodies must be limited to those that would engender the proper types of feelings in Athenian citizens. ${ }^{64}$ Finally, Plato would have the state regulate who could provide music in the ideal state. Because music was, for Plato, an instrumental good (pun intended), musicians in the Republic must be those who appreciated music's formative role and who chose not to pander to the populace's baser tastes. ${ }^{65}$

59. See PlATO, supra note 57, at 402 ("[N] either we nor our guardians, whom we have to educate, can ever become musical until we and they know the essential forms[,] . . believing them all to be within the sphere of one art and study."). But, the benefits of a proper musical instruction would be lost on the youth who was permitted to overindulge, for just as the athlete who does nothing else will become brutish and stupid, the musician who focuses solely on that art will become soft and weak. See id. at 411 (" $\Pi \mathrm{f}$ he carries on the softening and soothing process he begins to melt and waste.").

60. See id. at 410 ("And thus our youth, having been educated only in that simple music which, as we said, inspires temperance, will be reluctant to go to law.").

61. See PLATO, supra note 57, at 85 (" $[\mathrm{B}]$ eauty of style and harmony and grace and good rhythm depend on simplicity.").

62. Id. at 83 .

63. See id. at 81-84 (stating agreement among characters of Socrates, Adeimantus, and Glaucon on principle that music should conform to lyrics). This passage was seized upon by certain Renaissance theoreticians and composers. See infra notes 389-91 and accompanying text.

64. PLATO, supra note 57, at 82 ("Of the harmonies I know nothing, but I want to have one warlike . . . and another to be used by him in times of peace and freedom of action.”).

65. See id. at 80-81:

$[\mathrm{T}]$ here is another sort of character who will narrate anything ... [ [H] e will attempt to represent the roll of thunder, the noise of wind and hail, or the creaking of wheels, and pulleys, and the various sounds of flutes, pipes, and trumpets, and all sorts of instruments .... [W] e must ... inform him that in our State such as he are not permitted to exist; the law will not allow them. 
Aristotle's views on the power of musical communication were more sanguine than Plato's, but he agreed that music needed to be regulated by the state. Like Plato, Aristotle acknowledged that musical education was customary, ${ }^{66}$ although in his opinion it had become focused on training for leisure rather than as ethical training. ${ }^{67}$ He concluded that legislators should require youth to practice the art to experience fully its ability to express virtue and because musical instruction could serve as the spoonful of sugar to help the medicine of a proper education go down. ${ }^{68}$ He urged that the state regulate the musical curriculum, by, for example, banning the use of flutes ("too exciting") 69 and limiting practical instruction to the "ethical" melodies. ${ }^{70}$ Sharing Plato's disdain for musical virtuosity, Aristotle concluded that children should be educated in music only enough to be good critics. ${ }^{71}$ Aristotle rejected "the professional instruments and also the professional mode of education in music (and by professional we mean that which is adopted in contests)." 72 In his view, professional performance in music involved pandering and vulgar specialization, making it the provenance "not . . of a freeman but of a paid performer.", 73

See also Henderson, supra note 44, at 396 (stating that Plato's targets were professional musicians, normally aliens, whose music entailed instrumental virtuosity).

66. See Aristotle, Politica, in 10 THE Works of Aristotle Translated into English 1338a, 35-36

(Benjamin Jowett trans.) (W.D. Ross ed. 1921) ("[M]usic is one of the received and traditional branches of education.").

67. See id. at 1337b, $28-29$ ("Concerning music a doubt may be raised - in our own day most men cultivate it for the sake of pleasure."). Aristotle also considered whether the state should require musical education. Rehearsing the dominant arguments of his day, he wrote:

It is not easy to determine the nature of music, or why any one should have a knowledge of it. Shall we say, for the sake of amusement and relaxation, like sleep or drinking, which are not good in themselves, but are pleasant, and at the same time 'make care to cease', as Euripides says? ... Or shall we argue that music conduces to virtue, on the ground that it can form our minds and habituate us to true pleasures as our bodies are made by gymnastic to be of a certain character? Or shall we say that it contributes to the enjoyment of leisure and mental cultivation, which is a third alternative?

Id. at $1339 \mathrm{a}, 14-26$.

68. See id. at 1340b, 10-17:

Enough has been said to show that music has a power of forming the character, and should therefore be introduced into the education of the young. The study is suited to the stage of youth, for young persons will not, if they can help, endure anything which is not sweetened by pleasure, and music has a natural sweetness.

69. Id. at $1341 \mathrm{a}, 22-23$.

70. See id. at 1342a, 3-4, 28-30; see also 1341b, $32-35$ (accepting division of melodies into "ethical melodies, melodies of action, and passionate or inspiring melodies" with corresponding modes).

71. See id. at 1341a, 10-15:

The right measure will be attained if students of music stop short of the arts which are practiced in professional contests, and do not seek to acquire those fantastic marvels of execution which are now the fashion in such contests, and from these have passed into education. Let the young practise even such music as we have prescribed, only until they are able to feel delight in noble melodies and rhythms.

72. Id. at 1341b, 7-9. See infra notes 89-92 and accompanying text on musical contests.

73. See AristotLe, supra note 66, at 1341b, 13-14; see also id. at 1341b, 15-17 ("The vulgarity of the 
Unlike Plato, Aristotle believed exposure to the more passionate, even ecstatic, music had its place. ${ }^{74}$ In addition, for Aristotle, music also served a useful role as a form of "intellectual enjoyment in leisure; which is in fact evidently the reason of its introduction, this being one of the ways in which it is thought that a freeman should pass his leisure." 75

\section{The Social Role of Music and Musicians}

Modern copyright grants exclusive rights in music to the author, that is, the composer or the composer's employer. ${ }^{76}$ One justification for the grant of such rights is to sustain a class of professional composers and musicians. In the classical world, the economies of the ancient Greek citystates were sufficiently complex to support a specialized class of musicians, although many musicians also provided other forms of entertainment. But these musicians generally were not in a position to claim a proprietary relation to the music they produced, and such claims would have been alien to the musicians' employers or patrons. Information about whether ancient Greek musicians were paid is inconsistent. If musical performance, as Aristotle and Plato suggest, was the provenance of slaves, then slave musicians were probably not paid, for the concept of wage labor for slaves was absent in ancient Greece. ${ }^{77}$ Some evidence indicates that a class of free persons also composed and performed music for wages, although we have only sparse indication of what those may have been. ${ }^{78}$

spectator tends to lower the character of the music and therefore of the performers.").

74. See id. at 1342a, $1-2$.

75. See id. at 1338a, 21-24.

76. See 17 U.S.C. $\$ 201$ (2000).

77. See Grant, supra note 53, at 286. Prior to the fifth century B.C.E. most laborers in the Greek world were free although they may not have enjoyed citizenship. See id. at 282-87 (describing classifications of residents in Greek city-states). Athens increasingly came to rely on slave labor and in the fifth century it appears that more than a quarter of the population-between 60,000 and 100,000 - "were the property of their masters, dependent upon them in every sphere of life, and if liberation ever came their way, it came only as their masters' free gift. In point of rights, slaves were no better than his tools." Id. at 286.

78. See ADKINS \& ADKINS, supra note 41, at 187 ("Evidence for wages during the Greek period is sparse .... There is also little indication of how the labor of slaves, who could be bought or leased, and the labor of dependent tenants affected the wages of free laborers."). There are some "indications that ... [p]hysicians, musicians, actors, hetaerae, the best teachers and some highly rated artists received wages above the average, but few precise figures are known." Id. at 188. For example, Pindar, who boasted of noble lineage, may have been a professional musician. See Henderson, supra note 44, at $390 \&$ n.3 (referring to references to Pindar's fees).

Women also were professional musicians, but, it appears that they were given less recognition and some were pressed into service as prostitutes as well. See ADKINS \& ADKINS, supra note 41, at 409 ("Many hetaerae were professional dancers and musicians, hired to entertain at men's functions such as symposia, and many were highly accomplished."); JACOB BURCKHARDT, THE GREEKS AND GREEK CiviLIZATION 203, 259 (Sheila Stern trans.) (Oswyn Murray ed. 1998) (describing symposia); Ann N. Michelini, Women and Music in Ancient Greece and Rome, in WOMEN AND Music: A History 21, 23 (Karin Pendle, ed., 2d ed. 2001)[hereinafter WOMEN AND MUSIC]: 
More complete is information on the funding of festival choirs, funded by a tax on the wealthier citizens. ${ }^{79}$

Importantly, in a culture that appreciated the power and value of the written word as a form of storing and transmitting knowledge, and in a culture that recognized the writer of the written word as an author expressing an individual point of view, we find no similar treatment for the composer of the written musical note. Instead, the theoretical texts describe a system to be used to generate music, a system formally composed of modes (roughly musical scales), and an informal set of background melodies and conventions for improvisation. Although a system for musical notation had been invented, ${ }^{80}$ its use was not widespread. Musicians had limited compositional freedom, and there were penalties for straying from the accepted conventions. ${ }^{81}$

Consequently, the notion of a composer (or his or her patron) having a proprietary relation to a particular melody generated within the system and conventions would have been thoroughly alien to the Greeks' relation to their music. The system for generating music was in their view part of a larger, beautiful system created by divine power and which ordered the cosmos. The specific conventions governing musical expression reflected the norms and collective culture of the Greeks and could not be individually appropriated. ${ }^{82}$

Women were also strongly associated with playing the aulos, but here the aspect of class stratification becomes more prominent. A large class of professional, female aulos players, most of whom seem to have been slaves, were hired out to perform at all-male drinking parties; often the piper is depicted nude, suggesting that she functioned as a prostitute as well. Segregation of the sexes meant that women who came into the male world, like those hired to play music, received little pay and were accorded low status.

Differences in status between male and female musicians were relative, because more generally "artists were regarded with the same contempt that was the lot of all who devoted their lives to a particular task, a specialty; the musicians and many poets were in the same case." BURCKHARDT, supra, at 193 (relying on Roman sources).

79. See BuRCKHARDT, supra note 78, at 182 (funding of the tribal chorus became "one of the most important civic duties"). Membership in the chorus depended on the city-state and festival, with Athens tending toward tribal organization and Sparta opening membership more widely. See Nigel M. KennelL, The Gymnasium of Virtue: Education and Culture in AnCient Sparta 66 (1995) (describing choral membership). According to Plutarch, in latter years, money prizes had to be offered to induce funding of festival choirs. See BURCKHARDT, supra note 78, at 389 n.30 (describing Plutarch's view of money prizes).

80. See ADKINS \& ADKINS, supra note 41, at 264-65 (stating that there were two types of alphabetic notation, one for the voice and one for the instruments).

81. See Grout \& PALISCA, supra note 46, at 16 (“[M] usicians did not read from notation; performers relied on their memories and knowledge of traditional musical formulas and conventions."); ROMAIN GOLDRON, ANCIENT AND ORIENTAL MUSIC 109 (1968) (stating that Greek music was monodic, based on traditional melodies, and that the performer's task was to "choose the melodic formula suitable for each occasion, and to decorate it accordingly"); GROUT \& PALISCA, supra note 46, at 17 ("There were precedents for banning certain kinds of music in the interests of public welfare: music was regulated in the early constitutions of both Athens and Sparta.").

82. Lest the modern reader conclude that the cultural constraints on ancient Greek composers made their music less "original" and therefore less appropriately the subject of property rights, be aware that modern 
Moreover, for music to be treated as a form of individually-owned property, a persona who claims a proprietary relation to it must first exist. No individual cultural or legal persona- "the composer" or "the publisher" - had emerged who would be in a position to claim a piece of music was "theirs." 83 As for "the performer," some performers created the music they performed, but they understood themselves to be giving voice to an existing cultural script rather than creating a new one. ${ }^{84}$ By contrast, Greek poets, playwrights, and philosophers all had emerged as self-aware subjects exploring and expressing their subjectivity through their writings. ${ }^{85}$ While none of those who played these social roles claimed a proprietary relation to their written objects or the intangible expression embodied in those objects, they did receive attribution and acclamation for their written work. To make the distinction quite pointed, evidence suggests that famous playwrights such as Sophocles and Aristophanes also composed the music used in their works. ${ }^{86}$ Their plays have been preserved and attributed; their music has not.

\section{Musical Practice in Ancient Greece}

Ancient Greek life appears to have been saturated in music, although we have only a vague notion of who composed it or how it may have sounded. ${ }^{87}$ Music was performed principally in the home, in connection with rites of passage and other religious rituals, in contests of musical virtuosity, in the theater, ${ }^{88}$ and in connection with military exercises and

popular music - in which the most economically valuable property rights reside — similarly is generated by a system comprising a narrow range of scales, chord progressions, and melodies-most of which derive from forms of folk music, especially the blues, that have been around for hundreds of years.

83. See Henderson, supra note 44, at 400 ("The modern figure of the pure composer, who is neither poet nor player, was unknown to antiquity.").

84. See id. ("From the fourth century B.C. onwards the musician thought of himself as an actor rather than creator or 'discoverer' (as Greeks preferred to put it).”).

85. Some historians of intellectual property claim one Greek city-state that afforded cooks patent-like protection in their new dishes is the earliest example of intellectual property protection. See, e.g., Paul Edward Geller, Copyright History and the Future: What's Culture Got To Do With It, 47 J. COPYRIGHT SOC'Y U.S.A. 209, 212 n.12 (2000). It is questionable whether this regulation instantiates the concept of intellectual property, but even if it did, commentators acknowledge that the concept did not apply to other fields, including music. Id.; see Olcott, supra note 48, at 1052.

86. See infra note 91 .

87. Surviving Greek notation relies on background knowledge that is lost. Musicologists hypothesize that the music would most closely resemble contemporary music from southeast Asia, such as Indian raga, or Japanese bokyoku, with a single melody line repeated and varied in various rhythmic patterns. See, e.g., JEREMY YudKIN, Music IN MEDIEVAL EUROPE 25 (1989).

88. See, e.g., MATHIESEN, supra note 41, at 1-13 (detailing recent discoveries of primary sources for understanding ancient Greek music and remaining mysteries); SACHS, supra note 25, at 198-99 (describing the 11 pieces of Greek music recovered by 1943, including a song from Euripides' Orestes and the First Pythian Ode, questionably attributed to Pindar); Grant, supra note 53, at 39 (music and dancing "essential" to early 
displays. In public life, musical performance and virtuosity were viewed as part craft, part sport. For that reason, public performances took the form of contests - the ancient predecessors of modern battles of the bands. ${ }^{89}$ Competition was intense, and winners were handsomely rewarded monetarily and with fame comparable to that accorded star athletes. ${ }^{90}$ Vocal choruses-often featured in both comedic and tragic dramatic works ${ }^{91}$-also competed at the festivals. ${ }^{92}$

performances of tragedy); $i d$. at 130 (Euripides' works reputed to be accompanied by "most original whirling and trilling music"); Henderson, supra note 44, at 390-91 ("The greatest of comedians [Aristophanes] was himself probably the greatest of Athenian composers, and certainly the greatest of Greek musical critics.").

89. See Chailley, supra note 25, at 97 ("When the ancient Greeks met together to hear virtuoso performers, they tended to look upon these occasions as sporting rather than musical events: the cithara contests were, in their view, on the same level as running or boxing."); SACHS, supra note 25, at 270-71 ("Sportive competition ... so dominated Greek musical life that even mythology saw music in the form of challenge and duel.").

It appears that these contests began in the amphitheater of Apollo's temple in 586 B.C.E., at the same time as the Pan-Hellenic athletic games started. See Yehudi MenuHin \& CurTis W. DAvis, The Music OF MAN 39 (1979); GROUT \& PALISCA, supra note 46, at 3 (describing account of musical competition held at Pythian games in 582 B.C.E.); see also Henderson, supra note 44, at 379 (stating that some writers purported to trace origin of musical competitions to earlier era, but evidence of such competitions is elusive). Competitive pressures and the demands of an increasingly sophisticated audience drove ancient Greek musicians to develop increasingly complex musical compositions. See GROUT \& PALISCA, supra note 46, at 3-4 (stating that increased number of virtuosos led music to become more complex and "showy"). Copycat competitions quickly arose in connection with other festivals. Eventually, however, a backlash against the complexity of these performances ensued, and Greek musical performance and theory became somewhat simpler. See Donald J. Grout, A HistORY OF WESTERN MUSIC 4 (2d ed. 1973) (stating that some time during the period between 450 to 320 B.C.E. a reaction set in against technical complexities in music).

Common elements in these festivals included a formal procession to the shrine of a deity, decorating wooden symbols of the deity, choral performance of hymns, athletic, music and drama contests, and animal sacrifice. ADKINS \& ADKINS, supra note 41, at 348. The most prominent musical contests took place at the Pythian Games, held at Delphi in honor of Apollo. The competition included opportunities for instrumental soloists as well as vocalists with instrumental accompaniment.

90. See BURCKHARDT, supra note 78 , at 182-83 (describing intensity of competition in artistic matters); Henderson, supra note 44 , at 400 (describing sums paid to stars). In addition to a monetary sum, winners received the bay-leaf wreath of the Games, and fame, reflected at times in poetic adulation. Pindar's "Twelfth Pytbian Ode was written in honor of Midas of Akragas, winner of the aulos contest in 490 BCE; Pindar regarded this victory by an aulos player as seriously as he did those of the victorious athletes." WALDO E. SWEET, SPORT and ReCreation in AnCient Greece: A Sourcebook with Translations 183, 185 (1987). Fame had its flipside as well. One tale has it that a man who boasted of his skill on the lyre failed to impress the audience and was ruthlessly scourged and expelled from the sanctuary. Id. at 389 n.28 (citing Plutarch, Against Ignorance at 9).

While Plato railed against the vulgarity of these public spectacles, Aristotle chose to rationalize their existence. See ARISTOTLE, supra note 66, at 1342a, 19-27:

[S]ince the spectators are of two kinds - the one free and educated, and the other a vulgar crowd composed of mechanics, labourers, and the like- there ought to be contests and exhibitions instituted for the relaxation of the second class also .... A man receives pleasure from what is natural to him, and therefore professional musicians may be allowed to practise this lower sort of music before an audience of a lower type.

91. Choral music was almost all melodic, with virtually no harmonization. Choruses, for example, sang in unison, with no deviation from the melody, although the accompanying musician may sometimes have deviated from the melody. In tragic Greek drama, recited passages alternated with musical passages sung by the chorus. See GRANT, supra note 53, at 39. The music used by Euripides drew particular praise. See id. at 130 
In the domestic sphere, consistent with Plato's and Aristotle's prescriptions, musical education for young Greeks was compulsory. ${ }^{93}$

(characterizing Euripides' lyrics as "dazzling and fantastic" and the music as "whirling and trilling"). In comedy, Aristophanes, for example, deployed a 24-member chorus, which danced and sang while developing the plot and eventually taking the "hero's" side. See id. at 140. Renaissance composers who invented opera were inspired by Greek use of music in tragedy.

92. BURCKHARDT, supra note 78 , at 182 ("In drama, it seems, tragedy as well as comedy were competitive almost from the beginnings; this is equally true of all the festival choirs.").

93. See Francois Chamoux, The Civilization of Greece 306-07 (W. S. Maguinness trans., 1965) ("[M] usic played a primary part in the education of the young Greek."). Citizens, by definition, were men. See GRANT, supra note 53, at 279 (“ [] $\mathrm{n}$ the city-states in general women never possessed citizenship."). Solon's laws required that fathers provide for the education of their sons, and specifically that the boys be taught music and gymnastics. At the age of six or seven, a boy would leave the company of the women in the gynaeceum and begin to go to school, accompanied by a slave called the paidagogos. The schools were private establishments and the masters received fees from the children's parents. The grammatistes taught reading, writing, and arithmetic and made his pupils learn by heart the poems of Homer, Hesiod, Solon, and Simonides. See id.

Evidence suggests that young women also received a musical education, although some doubt exists as to whether that education occurred in the home or in the schools attended by the boys. See Michelini, supra note 78, at 23 (stating that girls were not formally trained but nonetheless learned to play music). One goal of a young woman's musical education would have been to teach her the music performed by women in connection with wedding rituals. See ADKINS \& ADKINS, supra note 41, at 256.

Some evidence suggests that the Athenian music masters did not fully share Aristotle's disdain for musical virtuosity. See ARISTOTLE, supra note 66, at 1341a, 10-13 ("The right measure will be attained if students of music stop short of the arts which are practised in professional contests, and do not seek to acquire those fantastic marvels of execution which are now the fashion in such contests, and from these have passed into education.").

According to Chamoux, "The music master taught his pupils to play the lyre and even the cithara, a more complicated instrument to handle, demanding a technical competence not entirely in keeping with the traditions of a 'liberal' education." CHAMOUX, supra, at 307; see also Henderson, supra note 44, at 391 (citation omitted) ("Boys of the upper classes went to a music-master, and in company they were expected to intone their piece of epic or to sing the classics at meals."). In addition, Greek youth were taught to sing solo, in chorus, and with instrumental accompaniment. Vocal harmony was not taught, as part singing was unknown. See SwEET, supra note 90 , at 185.

Musical education also was required in Sparta, notwithstanding Artistotle's claims that the Spartans learned only an appreciation of music but did not learn to play. See ARISTOTLE, supra note 66, at 1339b, 1-2; see also KENNELL, supra note 79, at 17. In fact, "[u]ntil the mid-5th century B.C. Sparta was the musical center of Greece, and Terpander is said to have founded a school of music there, where the flute and lyre were taught." ADKINS \& ADKINS, supra note 41, at 263; see also CHAMOUX, supra, at 306-07 (stating that Spartans were taught choir-singing and learned the poetry of Alcman, Terpander, and Tyrtaeus).

Spartan education was different from Athenian education in that it was extremely militaristic and geared toward producing warriors, not "citizens." Therefore "[t]he place alloted to intellectual training in this system was manifestly restricted: it was limited to choir-singing, study of the national poets, Alcman, Terpander, and Tyrtaeus, and the inculcation of a harsh and narrow civic morality." Id. at 307; see also ADKINS \& ADKINS, supra note 41 , at 253 ("Between the ages of 7 and 20 , boys were removed from their families and housed in state barracks, where the emphasis was on sports and physical education, as well as dancing and music (because of their military uses), but only basic reading and writing."); KENNELL, supra note 79, at 110 (“[N]o one was more devoted to music and song” (quoting Sphaerus's Laconian Institutions)). In Sparta, young women also received musical instruction. ADKINS \& ADKINS, supra note 41, at 253 ("Girls, as future mothers of warriors, also undertook physical training, gymnastics, dancing and music.”). 
Entertainment frequently came in the form of dinner gatherings, and music often accompanied socializing and drinking. ${ }^{94}$ Among intellectuals, performance of music outside the home was considered vulgar and inappropriate for any but slaves. This view is reflected in the writings of both Plato ${ }^{95}$ and Aristotle. ${ }^{96}$

\section{Fall of Greece; Rise of Rome}

During the second century B.C.E., the center of political and military power moved from Greece to Rome. Many of the Greek musical practices described above continued, now under the shadow of Roman power. Interestingly, we know even less about the practice of music in ancient Rome than in ancient Greece. ${ }^{97}$ Musical influences appear to have come from the Etruscans, the Greeks, and the cultures of the East. ${ }^{98}$ Roman elites appear to have regarded Greece as the source of art, music, and other branches of learning toward which they should aspire, especially after the Greek islands became a Roman province in 146 B.C.E. ${ }^{99}$

Rome developed a legal system to which most civil law systems trace their roots. One might ask whether Roman law supplies roots for the concept of copyright in music. It is almost certain that a right to prohibit

Children of Athens and Sparta, raised in two completely different types of societies, were therefore educated in music for the same purpose: to mold them into the kind of people they were expected to be in their respective worlds.

94. Wealthy Athenians enjoyed musical performance when they held symposia in their homes. A symposium was a drinking party following an evening meal attended by men alone, although betaerae [courtesans] might also be present as entertainers. ADKINS \& ADKINS, supra note 41, at 420. Music and other entertainment accompanied the pouring of libations, after which the conversation and philosophizing would begin. Id.; see also BURCKHARDT, supra note 78, at 203 (describing symposium ritual). A less aristocratic form of home entertainment was the ritual surrounding drinking songs, or scolia. See ADKINS \& ADKINS, supra note 41, at 256:

Scolia ... were drinking songs, mainly Attic, performed at banquets or drinking parties and accompanied by the lyre. A guest holding a myrtle branch would sing and then pass that branch to another guest. The term derives from skolios (crooked) because the scolia were sung in random (crooked) order. There is evidence for some choral scolia. Terpander was traditionally the originator of scolia. They were apparently popular in the 6th and 5 th centuries BC, but then stopped being composed.

See also Henderson, supra note 44, at 391 (describing scolia).

95. See Plato, supra note 57, at 98 (praising the musical theorist, the cosmic philosopher, above the "mere" performer, calling him "the true musician and harmonist in a far higher sense than the tuner of the strings").

96. ARISTOTLE, supra note 66, at 1339b, 8-9 (" $[\mathrm{N}]$ o freeman would play or sing unless he were intoxicated or in jest.").

97. See Grout \& PALISCA, supra note 46, at 15 ("We do not know whether the Romans made any significant contributions to the theory or practice of music."); see also J.E. Scott, Roman Music, in 1 NEW OXFORD HISTORY, supra note 25, at 404 (stating that most music sources for Rome concern instruments rather than the music they produced).

98. See Scott, supra note 97, at 404 (describing sources of Roman music).

99. See Grout \& PALisCa, supra note 46, at 15-16 (describing source of Roman “art music"). 
reproduction of intangible expression was not present in Roman law. ${ }^{100}$ Some commentators have argued that Roman law concepts of contract and of intangible property should be viewed as copyright's ancestors nonetheless. ${ }^{101}$ Even if one is persuaded that Roman legal principles animate modern copyright law, for purposes of the inquiry here we can be certain that musical expression had not come to be the subject of proprietary claims vindicated by law.

We also know that music was a part of every Roman's life. ${ }^{102}$ Although musical education seems to have been almost as important in Rome as it was in Greece, ${ }^{103}$ it was not a part of basic education. ${ }^{104}$ Romans appeared to have conflicting views about musicians. ${ }^{105}$ Conflicting reactions to musicians were brought to a head during the reign of Nero, who aspired to personal fame as a musician. ${ }^{106}$ Many in the upper classes viewed Nero's public performances as a disgrace, ${ }^{107}$ and most "Romans thought of dancing, singing, and lyre playing as undignified activities, effeminate for men and perhaps corrupting even for women." 108

Nonetheless, the Roman Empire, with its love for spectacle, brought back the competitions and complexities in music that Plato and Aristotle disdained. ${ }^{109}$ Nero aside, many of the emperors were patrons of music. ${ }^{110}$

100. See, e.g., Russ VerSteeg, The Roman Law Roots of Copyright, 59 MD. L. REV. 522, 523 \& n.13, 530 (2000).

101. See generally id.

102. See GROUT \& PALISCA, supra note 46, at 15-16 ("Music must have been part of almost all public manifestations.").

103. See id. at 16 ("Cicero, Quintilian, and other writers make it clear that cultivated people were supposed to be educated in music, just as they were expected to know Greek.”).

104. "Boys who needed, or who were interested in, mathematics and music would have to attend specialist teachers, usually Greeks, and, even though one such teacher might offer more than one subject, this would involve an additional fee." STANLEy F. BONNER, EduCATION IN ANCIENT Rome: From the Elder CATO TO THE Younger Pliny 77 (1977).

105. As a trade guild, musicians appear to have been well regarded. See Scott, supra note 97, at 410-11 (stating that musicians "had a well-defined status" and that Plutarch reports that pipers were listed as the first trade guild). On the other hand, "Athenaeus relates that in 167 B.C. when they saw for the first time a gathering of musicians, they asked what they were there for and then, so as to have their money's worth, insisted that they should all play together and then end up with a boxing match." CHAILley, supra note 25, at 97.

106. GROUT \& PALISCA, supra note 46, at 16.

107. See Henderson, supra note 44, at 401 (describing Roman disdain for professional approach to music); Scott, supra note 97, at 417 ("Society was shocked by Nero not because of his appearing as a musician, but because he posed as a professional artist."). Compare the Romans' reaction to that of United States residents to a saxophone-playing President or a guitar-playing presidential candidate. See, e.g., Michael Janofsky, Political Points, N.Y.Times, Sept. 14, 2003, at A28 (describing fundraiser at which candidate John Kerry jumped onstage to play Bruce Springsteen's "Tenth Avenue Freeze-Out" with the band and describing how one audience member declared that "the guy rocks out").

108. Michelini, supra note 78, at 24; see also Henderson, supra note 44, at 401.

109. See GROUT \& PALISCA, supra note 46, at 16 ("Ancient writers tell of famous virtuosos, large choruses and orchestras, and grandiose musical festivals and competitions."); SACHS, supra note 25, at 272 ("Seneca, who lived at the beginning of the first century A.D., complains that orchestras and choruses grew to gigantic proportions, so that there were often more singers and players in the theater than spectators.").

110. See Grout \& PalisCa, supra note 46, at 16 ("Many of the emperors supported and cultivated 
Perhaps even more so than in Greece, a star system appears to have developed for performers with the right combination of charisma and virtuosity. ${ }^{111}$ Roman music was well funded until the Roman Empire began to decline. ${ }^{112}$ Finally, although the book trade became more fully developed in the Roman Empire, ${ }^{113}$ we similarly do not find trade in musical manuscripts. Apparently, music was viewed as evanescent.

\section{Summary}

Music was not a form of property in the ancient world. Instead, it was a gift from the gods expressed in a set of musical conventions to which composers and performers were expected to adhere and which reflected the greater mathematical order of the cosmos. We have little information about who composed the music, but we know that music was important enough to finance specialization by performers and, perhaps, composers, or at least poets and playwrights who also may have composed music. The raw materials for the commodification of music were present. Notation systems and, later, paper were available. These elements were combined in the rudimentary commodification of literary texts, but musical texts remained largely unfixed and stored only in cultural memory.

Slaves were substantially involved in musical production, performance, and education. Although slaves themselves were culturally and legally property, the music they created or performed appears not to have been subject to ownership. Performers and theorists rather than composers appear to have been the center of attention in the musical realm, and absent is evidence of any claims of proprietary relations to musical works by composers, performers, or the wealthy ancients who paid for composition and performance.

\section{B. Music in Medieval Europe}

Consistent with our traditional Enlightenment biases, this Article treats the period between the collapse of the Roman Empire and the fifteenth century as a single period with earlier and later segments, i.e., the Middle

\footnotetext{
music.").

111. See Scott, supra note 97, at 416 ("Successful individual players were mobbed by the crowd, paid fantastic engagement fees, and allowed to indulge in any amount of artistic temperament off stage or on stage."); GOLDRON, supra note 81, at 113.

112. See GROUT \& PALISCA, supra note 46, at 16 ("With the economic decline of the empire in the third and fourth centuries, the production of music on the large and expensive scale of earlier days ceased.").

113. See MARTIN, supra note 42, at 49 ("Publishing and the book trade were also developed in ancient Rome.”); Geller, supra note 85, at 213.
} 
Ages. ${ }^{114}$ During this period, three developments are of particular interest for the conceptual and legal development of exclusive rights in music. First, musical notation was (re)developed during this period. Notation was critical for the creation of musical texts, and the physical embodiment of these texts would become the subject of exclusive rights held by publishers during the Renaissance. Indirectly, by facilitating communication between composer and performer, notation enabled more complex compositions to be performed by large groups of musicians. The second development is that as demand grew for more complex composition, the rudimentary specialization of the composer began to appear in the latter Middle Ages. Eventually, composing would be seen as a distinct and human art entitling the composer to make proprietary claims to his or her compositions.

Finally, the development of medieval cities and universities were important. Urban economies and increasing trade led to the emergence of a bourgeoisie, who increasingly would become the consuming "public" for whom commodified music would be produced. It was also in medieval cities that we see in the musicians' guild restrictions the first legally cognizable exclusive rights in musical labor, which amounted to a form of rights in the music itself.

Modern views of medieval life must be tempered by recognition not only of the hermeneutic difficulties involved in interpreting the source material we have but also of the fact that we do not have sources related to many dimensions of medieval life. Written records reflecting musical practice in this period pertain largely to the practice in the Christian Church (hereinafter the Church). ${ }^{115}$ Having survived the disintegration of the Roman Empire, and having then split into Eastern and Western halves, the Church became the most powerful political and social institution in medieval life in Western Europe. ${ }^{116}$

For this reason, if the notion of medieval music conjures any sound or image for modern audiences, it would be that of robed monks singing "Gregorian" chant. ${ }^{117}$ Chant was the dominant form of liturgical music,

114. The "Middle Ages" received that designation from Renaissance writers who prided themselves on living during a rebirth of classical antiquity. See, e.g., YUdKIN, supra note 87, at 1.

115. See, e.g., Manfred F. Bukofzer, Popular and Secular Music in England, in 3 THE NEW OXFORD History OF Music: Ars Nova And Renaissance (1300-1540) 107 (Dom Anselm Hughes \& Gerald Abraham eds., 1960) [hereinafter 3 NEW OXFORD HISTORY] (" $[T]$ he art of reading and writing and of musical notation was a pursuit of the learned and was practised mainly in monastic centres and cathedral choirs.”).

116. As noted, supra note 9, because the legal propertization of music in the United States derives from the cultures and practices of Western Europe, this Article focuses on the musical practices there, even though considerable power resided, and significant musical developments occurred, in the Byzantine empire and places further East.

117. For example, a recent television advertisement created by BBDO for PepsiBlue juxtaposes a modern rock band with monks performing chant. For details, see http://www.pepsico.com/news/ pepsicola/2002/20020828p.shtml (last modified Aug. 28, 2002). See also Nat Ives, Marketers Turn Monks Into 
and the Church directly regulated the transmission of the chants of the Mass and of the various monastic Orders. The available story of early medieval music is that of political and religious unification and perpetuation of the "proper" Roman liturgy through a regulated form of chant.

We have very little direct information on secular musical developments during most of this period, ${ }^{118}$ but Church records reflect the penumbral influence of a vibrant secular musical practice-which sparked a response from the Church hierarchy. ${ }^{119}$ We know that the feudal system largely determined the economic and social basis for secular musical practice. It also appears that the border between sacred and secular music was porous, particularly with regard to melody. Popular melodies were translated from one sphere to the other when attached to new lyrics. ${ }^{120}$ The problem for historians has been that so little secular music composed or performed prior to 1200 C.E. was recorded because "new" compositions were viewed as short-lived variations on long-standing, collective traditions. ${ }^{121}$

The religious roots of written music and the ephemeral quality of secular music were not conducive to the development of proprietary claims in music. Some trace the first copyright case to the early Middle Ages, but that characterization is questionable. ${ }^{122}$ Moreover, even if the case of Columba and Finnian signaled the birth of copyright, the concept of a right to control reproduction of intangible expression did not extend to music.

Product Pitchmen, N.Y. Times, Aug. 25, 2003, at D1.

118. See, e.g., Theodore C. Karp, Music, in SEven Liberal ARTS, supra note 53, at 169, 178 (“Opinions concerning the relative richness of the secular musical culture before 1100 are based primarily on tantalizingly vague references in literary works and thus vary considerably among different scholars.").

119. See, e.g., Bukofzer, supra note 115, at 107 (stating that the Church's strongly-worded denunciations of secular song and dance music indicate that "this kind of music was considered a formidable enemy").

120. See id. at 108 (describing practice as "parody" or contrafactum).

121. MENUHIN \& DAVIS, supra note 89 , at 48 (“[B]y its very nature [music] was considered perishable.”).

122. The story involves Scotland's most famous saint, an Irish monk named Columba, and the abbot Finnian. Finnian had returned from Rome with a copy of St. Jerome's psalter, which he jealously guarded. Finnian permitted Columba to look at the book but forbade him from copying it. Columba disregarded the prohibition and was caught by Finnian in the act of copying. A dispute arose over ownership of the copy and the dispute was brought to the Celtic King Diarmait. He ruled that Finnian should have Columba's copy, reportedly stating, "to every cow her calf; to every book its copy." See, e.g., Geller, supra note 85, at 212 \& n.11 (citing J.A.L. STERLING, WORLD COPYRIGHT LAW 1027-28 (1998)); Masterson, supra note 43, at 624. A number of sources on the Web also have versions of the story. See, e.g., Saint Columba, Abbott, Confessor-521-597, available at http://www.ewtn.com/library/MARY/COLUMBA.htm (last visited Feb. 14, 2004); http://www.slis.ualberta.ca/cap03/sandra/columba.html (last visited Feb. 14, 2004). 


\section{Conceptual Role of Music}

Despite shifts in the economic base for musical production, the conceptual themes developed in antiquity remained predominant during most of the Middle Ages. Music performance and innovation became the province of Church employees rather than slaves. The conceptual basis for proprietary claims by either musicians or the Church was absent. Instead, the Church regulated musical expression in its quasi-sovereign capacity rather than as proprietor. Conceptually, music still was divine in origin and was to be produced for glorification of the deity. ${ }^{123}$ Similarly, the Church hierarchy understood the value of music to be its power to inspire divine thoughts and to influence- - for good or ill— the character of its listeners. ${ }^{124}$

The most revered and influential authority on music in the Middle Ages was Boethius (ca. 480-524). ${ }^{125}$ Borrowing extensively from Platonic and Aristotelian sources, Boethius divided music into three kinds: musica mundane, referring to the harmony of the cosmos; musica bumana, harmony of body and soul; and musica instrumentalis, audible music produced by instruments. ${ }^{126}$

\section{Church Regulation of Music Production and Practice}

Although Church leaders did not relate to liturgical music as their property, they did consider it their right and responsibility to stimulate production and performance of appropriate liturgical music and to suppress blasphemous or wayward sacred and secular musical expression.

123. For example, Basil the Great (ca. 330-ca. 379) wrote of music as a gift from the Holy Spirit designed to facilitate religious teaching. St. Basil, Homily on Psalm 1, in EXEGETIC HomiLies 152-154 (S. Agnes Clare Way trans., 1963) ("The delight of melody He mingled with the doctrines so that by the pleasantness and softness of the sound heard we might receive without perceiving it the benefit of the words."), reprinted in MUSIC IN THE WESTERN WORLD: A HISTORY IN DOCUMENTS 25-26 (Piero Weiss \& Richard Taruskin eds., 1984) [hereinafter MUSIC IN THE WESTERN WORLD].

124. Grout \& PALISCA, supra note 46, at 25. As with Plato and Aristotle, early Christian theorists did not dwell on the idea that "music might be heard solely for sheer delight in the play of sounds;" rather, music was the servant of religion. $I d$. at 25-26. For example, Augustine, who enjoyed singing and wrote a treatise $O n$ Music, understood the didactic power of music and "regarded it as a key to world order." Karl F. Morrison, Incentives For Studying the Liberal Arts, in SEVEN LibERAL ARTS, supra note 53, at 32, 40-42.

125. GROUT \& PALISCA, supra note 46, at 27.

126. See, e.g., Karp, supra note 118, at 175. Echoing his sources, Boethius wrote, "how much nobler is the study of music as a rational science than as a laborious skill of manufacturing sounds! It is nobler to the degree that the mind is nobler than the body." Boethius, De Principia, in CAlvin MARTin Bower, Boethius's The Principles of Music: AN Introduction, Translation, and Commentary 101-04 (1967), reprinted in MUSIC IN THE WESTERN WORLD, supra note 123, 37-38. For him, the musician's skill was less a matter of emotional expression than an ability to judge "the modes and rhythms, as well as the genera of songs and their mixtures, and the songs of the poets ... based on ... thought and reason." Id. at 38. 
Important to recall is that "the Church" was hardly monolithic. During the first half of the Middle Ages, Church leaders devoted considerable resources to consolidating the papacy's control over the institution and to proselytizing. Music played an important role in these efforts. ${ }^{127}$ The Church banned the use of musical instruments to distinguish sacred musical practice from the instrumental music featured in the festivals and rituals of the pagans from whose ranks the Church drew its converts. ${ }^{128}$ Sacred chants consisted of a single melodic line sung in unison by a chorus, and many different styles had proliferated throughout Western and Eastern Europe. ${ }^{129}$

Reflecting the importance of music to the liturgy and papal spectacle, specialization of musical performers within the Church began early. The Papal Choir is the earliest musical body of which a continuous record is available. Dating perhaps to the fourth century C.E. and certainly to the

127. For example, as "the Church" was in its early stages of formation, various Christian sects allied themselves and found others to be practicing heresy. See Miloš Velimirović, Cbristian Chant in Syria, Armenia, Egypt, and Ethiopia, in 2 The New Oxford History of Music, The Early Middle Ages to 1300, at 3-4 (Richard L. Crocker \& David Hiley eds., 1990) [hereinafter 2 New OXFORD HiSTORY]. One of the allegedly heretical sects, active in what now is Turkey, had adopted in its ritual allegedly heretical poetry set to the "catchy" melodies composed by the poet's son. See id. (telling story). The popularity of the sect's music alarmed other Christian groups, who responded by appropriating the melodies and combining them with new, acceptable, lyrics. Id. at 4-5.

128. Elie Siegmeister, MusiC AND Society 27 n.43 (1938); see also Richard L. Crocker, Introduction to 2 NEW OXFORD HISTORY, supra note 127, at xvii ("We have always known of the hostility of the Fathers towards instrumental music (including thereby a broad range of musical activity in Roman culture)."). Church policy did not reflect an aesthetic displeasure with instrumental music, rather its goal was to wean converts from their past practices. GROUT \& PALISCA, supra note 46, at 17. The organ, an instrument familiar to churches of many denominations today, was especially disfavored because it had been used in Roman combat and outdoor festivals. MENUHIN \& DAVIS, supra note 89, at 47 (stating that the organ did not return to favor in the West until the eighth century). In exchange for the loss of instrumental music, the Church gave singers of sacred music some improvisational freedom, permitting performance of improvised versions of hymns during services. See SIEGMEISTER, supra, at 19; Karp, supra note 118, at 180 ("Surviving evidence suggests that earlier singers permitted themselves a certain degree of freedom in the performance of chant while remaining within the bounds of an accepted formulaic framework.").

129. Recognition of the variety of chant traditions in the early Church is a relatively recent development. See Crocker, supra note 128, at xvi-xx (describing revisions made by new work in the field). One reason is that religious chants were not written until about 900 C.E., giving us little information about the specific content of these chants. See id. at xv. Historians do have some ideas about how the traditions differed. See generally, Velimirović, supra note 127 (describing Christian chant in what now is Syria, Armenia, Egypt, and Ethiopia); Kenneth Levy, Latin Chant Outside the Roman Tradition, in 2 NEW OXFORD HISTORY, supra note 127, at 69 (describing Western European chants practiced outside Rome).

The practice and role of the chant appear to have had certain commonalities. The music itself was sung, unaccompanied by instruments, and was known as plainsong. It was "a free melodic chanting of sacred texts, intense yet devotional and serene, drawing on the natural stress of language for its rhythm and on the length of a human breath for its phrasing." MENUHIN \& DAVIS, supra note 89, at 47. Plainsong was "an active kind of music. The singer did not sing in order to be heard, but for the sake of singing, to offer up his song to God and to surpass himself in singing it." Chailley, supra note 25, at 68. And although the people did not participate in all the psalm-singing, "the soloist's song had to be approved collectively; that is the meaning of the final Amen sung by the faithful, and of the primitive refrains forming the 'responses."' Id. at 69. 
fifth, the Choir's task was to perform the music (plainchant) necessary for celebration of Mass. ${ }^{130}$ Not surprisingly, the approach to the music by the early choirs was canonical; innovation was discouraged. ${ }^{131}$

In the late eighth century and into the ninth century, as the Church became the official religion of an increasing percentage of the nobility and those living in their respective domains, members of the aristocracy found divergent popular religious practices to be a menace. Church leaders took measures to regain control of the liturgy and the music from the people. ${ }^{132}$ To create and reinforce the idea of a unified Church subject to control by the Pope, Church leaders embarked on a concerted politico-religious campaign to bring uniformity and control over liturgical music. ${ }^{133}$ Church authorities joined by Charlemagne and other Frankish ${ }^{134}$ or Carolingian ${ }^{135}$ monarchs in northern France pushed the development of musical notation as a tool in the effort to control liturgical music. ${ }^{136}$

\section{Development of Musical Notation}

For our purposes, the development of musical notation is critical because it enables the objectification of musical expression. Serving as a common language for composers and musicians, notation permitted music to take on an external manifestation that could be read as well as heard. Once this new "space" for musical expression—the written page —was

130. See Henry Raynor, A Social History of Music: From the Middle Ages to Beethoven 1920 (1972). The establishment of a permanent choir in Rome, as well as the choir of the Cathedral of Our Lady of Antwerp, laid the foundation for increasing specialization of religious singers and musicians. However, initially, these choirs were staffed by members of the clergy and boys destined for that career- the quality of the singing was not considered to be the most important aspect of the performance. Edward E. Lowinsky, Music in the Culture of the Renaissance, 15 J. HIST. IDEAS 509, 510-11 (1954). The historical record does not divulge who composed most of the liturgical music. See, e.g., J. Michele Edwards, Women in Music to ca. 1450, in WOMEN AND MUSIC, supra note 78, at 42 (stating that at least seven women can be identified as composing Byzantine Christian chant between the ninth and fifteenth centuries). One exception is Hildegarde von Bingen (1098-1179), who composed seventy-seven religious songs and one music drama. See id. at 45-48. For more on the development of liturgical drama in the new millennium, see generally Susan Rankin, Liturgical Drama, in 2 NEW OXFORD HISTORY, supra note 127 , at 310.

131. RAYNOR, supra note 130 , at 20.

132. SiegmeISTER, supra note 128, at 27. In 364 A.D., the Council of Laodicea restricted performance of hymns to canonical psalmists, who had the right to mount the pulpit. Id.

133. Identifying a canonical body of liturgical chant was initiated "[i] $n$ order to suppress better the everpresent danger of heresy, which often crept in via the musical route, and to strengthen the authority of the Roman pope over the not always too submissive bishops of the outlying provinces." Id..

134. The term "Frankish" refers to a tribe or nation rather than a geographic locale. See, e.g., Richard Crocker, Medieval Chant, in 2 NEW OXFORD HISTORY, supra note 127, at 225.

135. The Carolingians were the ruling Frankish family or household. See $i d$.

136. See Grout \& PALISCA, supra note 46, at 37-38 (uniform notation "helped assure that from then on the chants would be sung the same way everywhere. Thus notation was both a result of the striving for uniformity and a means of perpetuating that uniformity.”). 
opened, subsequent developments were facilitated. We can infer that some musicians became more adept at using the notation system to express themselves, planting the seeds for specialization of "the composer." And, the new space allowed such musicians to create and explore more complex forms of expression because a notation system facilitates the expression and management of complexity.

The transition from oral tradition to written tradition was gradual, taking nearly four hundred years. ${ }^{137}$ While the Church could have sent emissaries to teach Church members the approved repertory orally, the number of chants was quite extensive, and establishing an official repertory would have been difficult without the ability to embody and freeze the authoritative texts in tangible media. ${ }^{138}$ The Church had to develop notation anew because the older Greek system of notation had been completely lost. Initially, the Church's demands for a notation system were not particularly complex. During the ninth century, when the single melody of a chant was being described, notation often comprised no more than a neume — a sign such as $(/)$ or $(\backslash)$ or $(/)$ — placed above the words to indicate the direction of the melody. ${ }^{139}$ This form of notation relied on the performers' extensive background knowledge of a melody's starting pitch and tempo. ${ }^{140}$

Along with a notation system, the Church's campaign to privilege some chants as authoritative required a narrative about authorship that would justify the chants' privileged status. Church leaders developed a legend that Pope Gregory I (590-604) wrote down certain chant melodies, guided

137. See, e.g. Leo Treitler, Oral, Written, and Literate Process in the Transmission of Medieval Music, 56 SPECuLuM 471, 488 (1981) ("The history of notation in the Middle Ages can be understood in the light of the incremental institution of controls ... as against the habits and constraints that the performer brought to the performance.").

138. See, e.g., Karp, supra note 118, at 180 (describing perceived need for notation).

139. See GROUT \& PALISCA, supra note 46, at 56; Levy, supra note 129, at 69-70 (early notation arose somewhere between the rivers Siene and Rhine). Other chant traditions began using neumes around the same time. See, e.g., Velimirović, supra note 127, at 12-13 (describing notation of Armenian chant); Miloš Velimirović, Byzantine Chants, in 2 NEW OXFORD HISTORY, supra note 115, at 48-54 (describing development of notation for Byzantine chants).

140. See, e.g., Karp, supra note 118, at 180 ("The notation was primarily of benefit to those already familiar with the melodies and the basic principles on which they were built."); Richard Crocker, Frankish Classification of Antiphons, in 2 NEW OXFORD HISTORY, supra note 115, at 166 (noting that in context where starting pitch and melody had been memorized for centuries, neumes were "most specific and rich in nuance of inflection and ornamentations ... because these were the parameters hardest to remember.").

Consequently, this method of notation exercised incomplete control over the performer because it was explicit only about the coordination of groups of notes with syllables of text. See Treitler, supra note 137, at 488. With early forms of notation, the oral tradition remained strong. In this oral process, "music is received and coded through hearing, retained schematically in memory, and performed or transferred to writing from some mental idea of it[]" and "hearing' should be broad enough to include the situation in which a cantor, compiling a book for his own use, sings—aloud or to himself - from written exemplars and writes down a version of what he has assimilated from his singing." Id. at 484. The "notator was not a copyist[; . . . he was copying and remembering and composing, all at once." Id. at 482. 
by divine inspiration. ${ }^{141}$ (It is well established that these melodies were not the work of Gregory. ${ }^{142}$ ) Using the notation system and the legend, authorities had drawn up a "catalog of approved songs and sent emissaries throughout the Christian world with instructions that these songs were henceforth to be the exclusive music of the Christian church."143

The notation campaign succeeded, and, as a result, almost the entire body of chant as we know it_- "Gregorian" chant_-comes from northern France with melodies that probably reflect Roman origins. ${ }^{144}$ The spirit of musical creativity could not be suppressed entirely, however. The record reflects repeated edicts designed to maintain the authority of Church texts against the threat of local variations, sometimes influenced by popular secular music. ${ }^{145}$

The notation campaign had inspired development only of a descriptive notation system, not a prescriptive one capable of communicating how an unfamiliar piece of music should be played. Development of a prescriptive system took considerably longer. ${ }^{146}$ During the tenth century, music remained monophonic, and the use of neumes became more detailed, featuring a colored line to identify pitch accompanied by directional signals. ${ }^{147}$ Written music still acted as a touchstone for regulating

141. SiegMeISTER, supra note 128 , at 19.

142. Id.; see also Kate Van Orden, Introduction to MuSIC AND THE CultureS OF PRINT xv-xvi (2000) ("In fact, the written versions of Gregorian chant were new, not from Gregory's time, and musical notation was itself an invention inspired by Charlemagne's desire to regularize sacred rituals north and south of the Alps.”).

143. SIEGMEISTER, supra note 128, at 27.

144. See GROUT \& PALISCA, supra note 46, at 23; Richard Crocker, Liturgical Materials of Roman Chant, in 2 NEW OXFORD HiSTORY, supra note 115, at 111,113-14 (describing debate as to whether Carolingian notation campaign required fealty to a single authoritative text—which has not been found — and concluding that whether such text exists, it is a "convenient way to refer to the result of the extraordinary efforts of the Carolingians to absorb and standardize for their own use the Roman rite and its chant"); Crocker, supra note 140, at 165 (describing importance of Frankish systems for classifying liturgical repertory as means for exercising control over such repertory); Crocker, supra note 134, at 226-27 (describing debate over source(s) of repertory standardized by Carolingians).

Standardizing the repertory was no mean task as the body of music to be standardized included both the music of the Mass and of the monastic offices-a body of music well in excess of 1,600 pieces. See Crocker, supra note 140, at 166 .

145. Siegmeister, supra note 128 , at 29. Choirs in monasteries began to innovate, in part to accommodate the vocal characteristics of choirs comprised of boys and men. Id.; see also RAYNOR, supra note 130, at 20-22 (describing monasteries' role in musical innovation). Although the evidence is indirect, musical traditions outside the Church appeared to have thrived. To the chagrin of some Church elders, the purity of a cappella chant became diluted as Church sacred music began to incorporate instruments, melodies, and styles from popular folk traditions. See id. at 26-27. "Cappella" means cloak and is the root of the word "chapel." See $i d$. at 49. The cloak of St. Martin was the holiest relic of the Frankish kings and its sanctuary was the cappella. The word subsequently became associated with a place of worship. Id. Once counterpoint and harmony were introduced into the chant repertory in the later Middle Ages, the controlling influence of the Roman church through music was considerably weakened.

146. See Treitler, supra note 137, at 489 (asserting that the transition from descriptive to prescriptive notation took about four hundred years).

147. See Grout \& Palisca, supra note 46, at 56; Levy, supra note 129, at 70. 
performance rather than as an edict. Treitler argues that multiple written variations of the same chants were visual reflections of the oral tradition because the copyist felt free to write the version he heard as he read the manuscript from which he was copying. ${ }^{148}$ Only later would a copyist's non-literal copy be deemed a mistake. ${ }^{149}$

Musical notation became more prescriptive in the eleventh century with the development of staff notation, which gave the composer a language with which to prescribe relative pitch (i.e., to specify the notes to be played). ${ }^{150}$ Because staff notation freed music from dependence on oral transmission, its development was "as crucial for the history of Western music as the invention of writing was for the history of language."151

During this period, we begin to find instruction manuals for performers. ${ }^{152}$ Guido of Arezzo (ca. 990-1056) was the author of the best known of these manuals. He invented the process called solmization, by which syllables from a popular chant were used to represent different pitches (do, re, mi, etc.), ${ }^{153}$ and invented an instructional method known as the "Guidonian Hand."" These manuals facilitated the spread of music literacy. ${ }^{155}$ Increased literacy and reliance by some composers on written music to communicate more complex forms of music were developments that established the necessary conditions for the eventual commodification of music.

Change remained gradual. Early staff notation did not specify the duration of notes with any precision, leaving rhythm subject to interpretation. ${ }^{156}$ Composers would have to wait another century and a half, until roughly the beginning of the thirteenth century, to have a language

148. See Treitler, supra note 137 , at $485-86$.

149. See id. at 486 .

150. See GROUT \& PALISCA, supra note 46, at 57; Treitler, supra note 137, at 489.

151. GROUT \& PALISCA, supra note 46, at 57.

152. Because Boethius had theorized about the conceptual role of music, his writings were of little use to the practitioner in need of instruction. $I d$. at 53. With the development of an authoritative canon, treatises in the Carolingian era and in the later Middle Ages were oriented more toward practice. Id.; see also Crocker, supra note 134, at 281 (identifying anonymous Northern Italian treatise Dialogus as the first "use of the monochord to teach the beginner and help his practise his intervals; and the use of the alphabet A to G, with repetition in the upper octave"). Musical guides taught students to sing intervals, to memorize chants, and, later, to read notes at sight. GROUT \& PALISCA, supra note 46, at 56.

153. See Crocker, supra note 134, at 282 (describing Guido's contributions). The hymn Ut queant laxis starts each phrase one step higher than the previous phrase, so its syllables were used. $\mathrm{Ut}=\mathrm{C}, \mathrm{re}=\mathrm{D}, \mathrm{mi}=\mathrm{E}$, $\mathrm{fa}=\mathrm{F}, \mathrm{sol}=\mathrm{G}, \mathrm{la}=\mathrm{A}$. This system is still used, with "do" for "ut" in English, and "ti" for B.

154. Music students "were taught to sing intervals as the teacher pointed with the index finger of the right hand to the different joints of the open left hand. Each joint stood for one of the twenty notes of the system; any other note ... was considered to be 'outside the hand." GROUT \& PALISCA, supra note 46, at 56.

155. Consistent with the principle of hermeneutic modesty, however, we should not assume that music notation had oral realization as its sole purpose. See Emma Dillon, Medieval Music-Making AND THE 'ROMAN DE FAUVEL' 49 (2002) (cautioning against imposing modern expectations on medieval musical texts).

156. See id. (describing shortcomings of early staff notation). 
with which to prescribe rhythm as well. ${ }^{157}$

As notation developed, its usefulness as a tool became more apparent to composers, who used it to innovate. Between the twelfth and fourteenth centuries, polyphonic composition and instrumental accompaniment were introduced into the liturgy, particularly in northern France. ${ }^{158}$ Polyphonic composition became more influential when a disputed papal election in the fourteenth century led Clement $V$ to remove his throne to Avignon, bringing the source of authority over religious music in close contact with the center of musical innovation. ${ }^{159}$ Musicians were self-conscious of the changes, as reflected in Phillippe de Vitry's musical treatise, Ars Nova (ca. 1320)..$^{160}$

Church authorities did not welcome the increasingly complex and ornate

157. See id. For example, by 1319, Johannes de Muris would write, “"The musical note is a quadrilateral figure arbitrarily representative of numbered sound measured by time."' Treitler, supra note 137, at 490; see also Lowinsky, supra note 130, at 528-29, 543 (crediting Muris, a mathematician, with insight that instead of the five accepted rhythms of the time, composition could use any rhythm specified as multiple of 2 or 3 ). This conception of writing differs fundamentally from the earlier use of neumes as supplements to oral transmission, and it describes the fundamental transition that notation had come to represent- the coordination of time with relative pitch. See Treitler, supra note 137, at 490-91. This conception represents the establishment of the written tradition, a tradition featuring "the composer producing finished works that circulate in stable form through closed written channels in scores that are blueprints for the performers, who must be able to read them in order to produce performances that are essentially identical from one time to the next." Id. at 473.

158. See generally Sarah Fuller, Early Polyphony, in 2 NeW OXFORD HisTORY, supra note 115, at 485 (describing origins and historical sources reflecting early polyphony); Janet Knapp, Polyphony at Notre Dame of Paris, in 2 NeW OXFord History, supra note 115, at 557 (describing innovations by Leonin and Perotin). Historians suspect that polyphonic developments in liturgical music may have been fueled by secular musical developments. See, e.g., RAYNOR, supra note 130, at 26-28.

Polyphony refers to the use of more than one melodic line. Polyphony includes simple harmonies — think of a Beatles song, for example—as well as more complex forms, such as counterpoint, which involves two or more distinct melodies moving in different directions- think of a J.S. Bach composition. Each line need not be sung by a vocalist. Polyphony also includes music that combines vocal and instrumental expression.

159. See RAYNOR, supra note 130 , at 36 .

160. See Gilbert Reany, Ars Nova in France, in 3 NEw OXFORD HISTORY, supra note 115, at 1-2. The other well-known composer in the new style was Guillaume de Machaut. See id. at 15-29 (describing and analyzing Machaut's corpus). Perhaps even in the fourteenth century musical stardom was a winner-take-all enterprise, as we know of few other composers from the period. See id. at 29.

Music also played an important role in the extraordinary Roman de Fauvel (1310-16), a biting allegory of aristocratic corruption with rich musical interpolations in the new style and likely composed by one or more persons, including de Vitry. See id. at 5; Dillon, supra note 155, at 13-28 (describing complex task of identifying authorship of the Roman de Fawve). The first version appears to have been written by a chancery clerk, Gervais du Bus, who signals his identity in an anagram at the end of some manuscripts. Id. at 14. The text was significantly amplified and reworked by someone identifying himself as Chaillou de Pesstain. Id. at 18. Dillon argues that notions of Romantic authorship should not cloud our perception of how a contemporary reader would have encountered the text. See id. at 70, 147-52 (emphasizing creative role of scribes); cf. Judith A. Peraino, Monophonic Motets: Sampling and Grafting in the Middle Ages, 85 Music Q. 644, 674 (2001) (discussing "sampled" melody deployed in the Roman De Fawvel, which "presumes a quite sophisticated reader, one who is not only literate and acquainted with a repertory of animal and interpolated verse narratives, but also who can read mensural notation and recognize melodies by sight, for hearing of polyphonic motet would not readily leave that particular melody ringing in the ears"). 
music. Clement's successor, John XXII, tried in vain to stem the tide of innovation, commanding in a Papal Bull that "no one shall henceforth consider himself at liberty to use [polyphony] in the singing of the canonical Office or in solemn celebrations of the Mass." ${ }^{\prime 161}$ The increasingly divided and corrupt Church authorities, however, were losing control over the liturgy and the congregation: liturgical polyphony continued to flourish. ${ }^{162}$

Ironically, the Church, having put its institutional muscle behind the development of musical notation to better control the content of music composed and performed by the faithful, found that the tool of control had facilitated the development of new forms of musical expression the Church could not successfully suppress. ${ }^{163}$ Moreover, notation was a necessary precondition for the creation of musical texts, which would become subject to control through legal vindication of proprietary claims in both the tangible texts and the intangible work embodied in those texts.

\section{Secular Musical Practice}

The two secular developments most important for the commodification of music were the emergence of the troubadours in the latter Middle Ages and the formation of musicians' guilds in the growing urban centers. ${ }^{164}$ The troubadours and their songs of love signal the emergence of selfaware composers/songwriters. Many paid to have their compositions transcribed, although these composers appear not to have asserted

161. RAYNOR, supra note 130 , at 37 (quoting the Bull, Docta Sanctorum). The specificity of the regulation is reminiscent of Plato. See id. (" $[\Pi$ t is not our wish to forbid the occasional use-especially on feast days [-] . .. of some consonances, for example, the octave, the fifth and the fourth.”).

162. Other developments signaled the papacy's decreasing control over devotional music. In the early fourteenth century, in the Italian city-states, groups known as the compagnie delle laude were organized by Dominicans, Franciscans, and other mendicant orders to receive religious instruction, aid the poor, and conduct their own liturgical services, marked by distinctive musical practices. See BlaKe WiLson, MusiC AND MERCHANTS: The LAUdesi Companies of RePublican FloRENCE 2 (1992) (describing laudesi companies). Florence was the center of musical composition by these groups, and the laudesi companies hired professional singers and instrumentalists to perform the liturgy. Id. at 3. These confraternaties had analogs elsewhere in Europe. See RAYNOR, supra note 130, at 71 (mentioning similar groups in France, Spain, and Portugal).

163. To be clear, musical notation was not a necessary precondition to the creation of polyphonic music in medieval Western Europe. Rather, musical notation better enabled polyphonic composition by creating a visual system for simultaneously representing the movement of many voices, and notation facilitated the coordination of performance of complex polyphonic music, particularly in the latter medieval period when measured music gave the composer the tool to direct the performers' timing in performance.

164. During the early and middle medieval period, we can infer that entertainers for aristocratic courts became more specialized. In an effort to mimic the Pope's use of the Papal Choir, many aristocrats employed trained vocalists to perform liturgical music at Mass and during religious festivals. Instrumental and other musicians would have been employed to supply dance music and music for secular festivals. Although secular music did not appear to have been subject to the same demand for standardization as liturgical music, we infer that a set of conventions and traditional melodies left some room for compositional innovation within otherwise established parameters. 
proprietary claims to their music. Musicians' guilds, precursors to modern performing artists' labor unions, made a set of proprietary claims to music, vindicated by law. Only guild members could publicly perform music within the city's jurisdiction. ${ }^{165}$

\section{a. Troubadours and Jongleurs}

Just as modern listeners may associate early medieval music with monastic chant, the other enduring image is that of itinerant musicians, particularly the troubadours. The modern use of the word troubadour, when ascribed to roving singer-songwriters such as Bob Dylan, conflates the practices of different groups of traveling performers. Most traveling musicians were known as "minstrels" or "jongleurs,"166 and the written records begin to mention them in the latter portion of the tenth through twelfth centuries. ${ }^{167}$ The division of labor in medieval Europe had not intensified to the point that secular musicians could sustain themselves solely through the performance or composition of music. ${ }^{168}$ Nonetheless, providing musical entertainment was an important part of the jongleur's role, as they played for a broad-based audience composed of "peasants during the cyclic festivals and at weddings; artisans and journey men at patron-saint celebrations; and at annual banquets, the bourgeoisie, nobles." "169 In this capacity, the jongleur's role as composer and repository of a vast repertoire of music for all occasions meant in many ways that the jongleur was the music, ${ }^{170}$ and that music was a common language spoken and understood in medieval Europe. ${ }^{171}$

In the eleventh and twelfth centuries, some French aristocrats also chose the life of the traveling entertainer. Known as "troubadours" or

165. Some guild members also composed music and made some preliminary proprietary claims in relation to those compositions. See infra note 204 and accompanying text.

166. The term "jongleur" is derived from the Latin joculare ("to entertain"). RAYNOR, supra note 130, at 46.

167. See, e.g., Grout \& PALISCA, supra note 46, at 58.

168. For example, in Germany, a kind of truth-in-labeling regulation was in force setting forth aristocratic expectations of one who calls himself a jongleur. He was to:

know how to invent, to make rhymes, to acquit himself well as a swordsman; to know how to play drums, cymbals and the Banernleier (hurdy-gurdy) well; to know how to throw up little apples and to catch them on the point of a knife; to imitate the songs of birds, perform tricks with cards and jump through hoops; to play the cittern and the mandoline, to handle the clavichord and the guitar, to string the seven-stringed rotte, to accompany well with the fiddle, and to speak and sing pleasantly.

RAYNOR, supra note 130, at 45 (citation omitted).

169. Jacques Attali, Noise: The Political EConomy of Music 14 (Brian Massumi trans., Wlad Godzich \& Jochen Schulte-Sass eds., 1985).

170. See id. at 14.

171. See, e.g., Grout \& PalisCA, supra note 46, at 58 (describing jongleurs' repertory). 
"traoubairitz"172 in southern France and "trovères" in northern France, these composers and poets would travel with instrumentalists hired to minister to the music (from which derives the word minstrel). ${ }^{173}$ Secular music in the late medieval period was expressed in three principal styles - the chanson, the dance-song, and the long narrative poem. ${ }^{174}$ Troubadour songs frequently expressed the feelings of courtly love ${ }^{175}$ or else told lengthy tales of brave deeds done. ${ }^{176}$

Modern readers should avoid romanticizing the life of the traveling entertainer. Even many modern musicians, particularly those who have not become well known, have ambivalent feelings about going on tour because the demands of travel are considerable and the unknown demand for their performance make such a venture financially precarious. Many are lured onto the road because the modern musical economy offers the prospect of stardom and its attendant benefits. The plight of the itinerant entertainer in medieval Europe, particularly jongleurs, was far riskier. The itinerant life that jongleurs led made them less beholden to any political or religious authority than most of the population. For this reason, jongleurs were considered a suspect and troubling influence by the Church hierarchy. ${ }^{177}$ Not all those in power so regarded them, however, as jongleurs proved themselves useful politically to crusaders who sought to enhance their glory. ${ }^{178}$ The political power of musical expression also was used to voice subversive themes, leading to royal decrees setting boundaries for acceptable topics of musical composition. ${ }^{179}$ Though

172. Troubairitz was the feminine form of the noun. See Edwards, supra note 130, at 28-30 (Karin Pendle ed., 2001) (describing compositions by Troubairitz).

173. Id. at 46. Attali takes a moderately different view, translating the Latin ministerialis as "functionary" and asserting that jongleurs became known as ménestral or ménestrier only after they had become domesticated.

174. See generally John Stevens, Medieval Song, in 1 New OXFOrD History, supra note 25, at 357. The chanson reflects the yearnings for courtly love. See e.g., id. at 367 ("Almost every troubadour or trouvére feels bound to proclaim — and some at very frequent intervals— that it is love and the joy which springs from love that cause him to burst forth into music and verse."). Dance music varied in theme and composition across Europe. See id. at 399-04 (comparing and contrasting Lain, French, and German dance-song). Epic narratives appear to have been sung for quite some time throughout Europe, although evidence of that is more recent in France than in England or Germany. See id. at 404-12. Of French epics, the Chanson de Roland is the best known today. See id. at 407 .

175. According to Robert Briffault, troubadour poetry often lacked the refinement and reserve associated today with the notion of courtly love. See RoberT S. BrifFault, THe Troubadours 119 (1965) (“To sum up, there exists in the poetic output of any troubadour of the twelfth century no shadow of ambiguity as to the frankly sensual character of the erotic passion which inspires it.").

176. In Germany, in the thirteenth century the Minnesänger emerged as a class of bourgeois or aristocratic composers and musicians who would later be celebrated in the operas of Richard Wagner. See RAYNOR, supra note 130 , at 45 .

177. One medieval theologian asked rhetorically: "Can a minstrel be saved?" and answered, "No; minstrels are ministers of Satan." Id. at 47 (citation omitted).

178. See Grout \& PalisCA, supra note 46, at 45; AtTAli, supra note 169, at 14-15.

179. AtTALI, supra note 169, at 15. 
enjoying greater liberty from political regulation and a variety of social conventions, jongleurs lived a marginal existence with little prospect for financial security. (That is, freedom sometimes is just another word for nothing left to lose.)

\section{b. Musicians' Guilds}

As medieval cities grew, public performance of music came to rest in the control of a guild of specialized performers who had the exclusive right to perform music at public gatherings within the city walls. ${ }^{180}$ The legal protection for musicians' guilds is an important development in the commodification of music. Although the exclusive right to public performance appears to be more a regulation controlling labor rather than one creating property rights, musical notation still was not widely in use for secular music and therefore control over the musical laborer was a form of control over the music itself.

The guilds were formed gradually. Beginning in the twelfth century, the growth of European cities and the founding of universities led to the domestication of most wandering musicians. By the fourteenth century, most European towns and cities had hired musicians to act as watchmen and timekeepers. ${ }^{181}$ Known as waits (England), Stadtpfeifer (Germany) or Pifferi (Italy), these musicians were tasked with the dual functions of standing watch to use their instruments - usually horns (shawms) - to announce travelers or danger, as well as providing music to accompany weddings and funerals in town. ${ }^{182}$ The emerging bourgeoisie saw musical accompaniment by professionals as one of the trappings of aristocracy they could afford to emulate. Increasing demand for musical service made the role of musician primary. ${ }^{183}$

180. Growth of the urban population was punctuated by outbreaks of fatal disease that caused overall population decline. Prior to 1000 C.E., urban populations ranged around 5,000 and never exceeded 50,000. See Fiona Kisby, Introduction: Urban History, Musicology and Cities and Towns in Renaissance Europe, in MUSIC AND MUSiCians IN RENAissance Cities AND TOWNS 1 (Fiona Kisby ed., 2001). The urban population was hit less hard by disease and famine in the latter Middle Ages and the percentage of urban dwellers increased between 1300 and 1500 (about $5-10 \%$ ). Id. at 1-3 (providing data on population in select cities from $1000-1600$ ).

181. See, e.g., WALter L. WOODFILL, MUSiCians IN ENGLiSH SOCIETY: From ELIZABEth TO CHARLES I 33 (1953).

182. RAYNOR, supra note 130, at 47,55-58; see also WOODFILL, supra note 181, at 42 ("In the cities music was becoming a social and ceremonial necessity with the formation of the town bands of waits, Stadtpfeifer and pifferi, who made instrumental music popular and more respectable.").

183. See, e.g., WOODFILL, supra note 181, at 79 (describing how increased demand for musical services led musicians to improve the quality of music which further increased demand for musical services). The music of the London waits was probably more sophisticated than that of most towns. Id. at 51. The waits in London helped form public taste in England because what their audiences heard and liked would have become the fashion throughout the country. $I d$. at 53. 
As musical performance became more clearly the craft that a medieval musician was to practice, the town musicians formed themselves into guilds to secure their positions from the competition posed by traveling musicians. ${ }^{184}$ By reconfiguring musicianship as a socially productive craft and by adopting an organizational framework used by other productive laborers, guild members improved their social and economic status. ${ }^{185}$ The guild was granted an official, regulated monopoly on public performance by the town council, ${ }^{186}$ and the exclusive privileges of guild membership, marked by gowns and insignia, made a career as a musician an attractive choice to pursue. ${ }^{187}$ When there was an opening in the company of waits, competition was fierce. ${ }^{188}$

The professionalization of musicmaking appears to have had mixed effects. On the one hand, the guild structure and improved social status may have contributed to a certain conservativism by guild musicians. The guild structure, with lengthy apprenticeships, appears to have stultified experimentation in some cases; whereas public taste favored variety and use of different instruments, such as the violin, and non-guild members offered this form of entertainment. ${ }^{189}$ On the other hand, the ideology of craft appears to have pushed some members to hone their skills and develop increasingly complex polyphonic music. For example, generations of the Bach family, of whom Johann Sebastian is the best known, were leaders of the guilds in a number of German towns. ${ }^{190}$ In addition, some

184. See ATTALI, supra note 169, at 15-16; RAYNOR, supra note 130, at 56.

185. See, e.g., WOODFILL, supra note 181, at 37 (describing wages).

186. See, e.g., RAYNOR, supra note 130, at 61 (wage scale established by statute). Although in current times, a wedding engagement is considered among the less desirable forms of public performance by some musicians, see, e.g., The Wedding Singer (New Line Cinema 1998), in the late Middle Ages and early Renaissance, the official town musicians jealously guarded their exclusive right to perform at all public gatherings within the town's gates, such as weddings and funerals. RAYNOR, supra note 130, at 57.

187. WOODFILL, supra note 181, at 42. As Woodfill writes:

Nearly every town had waits, valued and nourished them, and often increased the size of the group.... The protected status they enjoyed both in and out of town, probably even more than their small stipends, made their places valuable. Neither wealthy nor in rags, waits led respectable and reasonably secure lives, probably comfortable according to lower middle class or artisan standards but more interesting than most: waits shared in every festivity, public and private, knew everyone in the town and its countryside, worked late, and took to the road now and then. Necessarily circumspect in an age suspicious of wandering fiddlers, and therefore not as glamorous in memory as the old minstrels, waits contributed nonetheless mightily to the Id. at 108 . pleasures of their communities.

188. Musicians "competed hotly for vacant places, and the aldermen, expediently as well as properly, always seem to have let musicianship rather than sponsorship rule their judgment." Id. at 42. With some interruptions, musicians' guilds have been a part of the music business ever since. For example, in the United States, professional performers can choose to join the American Federation of Musicians. See History of the AFM (2003), available at http://www.afm.org/public/about/history.php.

189. RAYNOR, supra note 130, at 61-62.

190. See id. at 56 (describing Bach family involvement in guilds). 
guild musicians took on additional responsibilities by creating the precursor to the modern concert series. ${ }^{191}$

\section{Arrival of "the Composer"?}

Those who composed music during the Middle Ages also were performers, and we cannot say that the cultural or legal persona of "the composer" capable of making proprietary claims over new music had emerged during this period. However, the development of staff notation in the eleventh century, which opened up a new space for musical expression, did facilitate the communication of more complex forms of music. Those musicians who endeavored to explore this new musical space came to see music composition as a distinct craft even if they did not play a distinct social role when practicing that craft. For example, in his eleventh-century manual for performers, Guido also introduced methods for composing music. He taught readers how to invent melodies and how to combine two or more voices in simultaneous chanting. ${ }^{192}$ By formalizing a method for composition, Guido implicitly expounded a view of music composition as a practical, human art rather than as a matter of improvisational play or divine inspiration. Initially, however, the nascent practice of music composition did not bestow any particular honor on the early practitioners. ${ }^{193}$

By the fourteenth century this had changed. Composition had become a more involved and complex art. Manuals on compositional technique had begun to circulate. Modern musicologists are fairly certain that, although the written page enabled the composer to visualize more complex expression, late medieval composers composed polyphony successively — that is, writing the melody for one voice and then layering

191. Public concerts by professional musicians as entertainment separate and apart from festivals and ceremonies largely is an eighteenth century phenomenon, but the practice was anticipated by public concerts by late medieval/early Renaissance guild members in cities such as Antwerp. "In 1483 the custom was introduced for the town musicians to perform evening music daily in the town hall, most likely from the tower. Besides, on holidays they joined the singers in the cathedral in the performance of solemn musical services and their names appear constantly in the account books of the Congregation of Our Lady at the cathedral in Antwerp." Lowinsky, supra note 130, at 519.

192. See Grout \& PALISCA, supra note 46, at 51 .

193. "Our relatively modern notion of 'the composer' hardly matches the conditions and methods of the musician of the middle ages and has no parallel in the way in which the people of that time thought." RAYNOR, supra note 130, at 19; see also DILLON, supra note 155, at 47 ("[T] he notion of a composer was even more remote from medieval music-making than it was from literary production: performers, scribes, listeners were all in a sense 'composers', with the musical work constantly inviting intervention."). As one scholar puts it with regard to religious composition, "[ $\mathrm{t}]$ he faithful were not interested in the composer, but in what he had to say; and he only said what was dictated by the calendar of Church feasts." CHAILLEY, supra note 25, at 80 . 
on the other voices one by one. ${ }^{194}$

The development of notation was one step toward commodification, and the use of notation to create distinct works by increasingly self-aware composers - who would one day be in a position to claim a proprietary relation to their work - was another. The process of seeking attribution for composition evolved slowly. As Lowinsky writes, "It was characteristic of the Middle Ages that its greatest composers, men like Leonin and Perotin, did not sign their names to their compositions; we know them only from the testimony of contemporary theorists." ${ }^{\text {"195 }}$ However, some composers in the fourteenth century began to claim attribution by inserting their names into the lyrics set to music. ${ }^{196}$

In secular music, as with sacred music, no clear division between composer and performer existed at the time, but " $[\mathrm{w}]$ hen the functions of composer and performer were distinguished, traveling performers ... were accorded less status."197 The troubadours' practices reflect a growing compositional self-awareness. These aristocratic musicians could afford to have their compositions transcribed, although it was not until the thirteenth and fourteenth centuries that the task of collecting and copying the songs was taken seriously. ${ }^{198}$ In many cases, because the identity of the composer had been deemed unimportant, authorship became difficult to ascribe. ${ }^{199}$ More recently, historians have been able to identify the composers of a number of lyrics and some musical scores. ${ }^{200}$ However, no

194. See, e.g., Lowinsky, supra note 130, at 529, 544; see also Bonnie J. Blackburn, On Compositional Process in the Fifteenth Century, $40 \mathrm{~J}$. AM. MusicOlOGICAL SOC’Y 210, 213 (1987) (quoting from Renaissance treatise on composition contrasting older style of composition with then-contemporary method of simultaneous conception of harmony).

195. Lowinsky, supra note 130, at 525.

196. See id.

197. Edwards, supra note 130, at 36.

198. See RAYNOR, supra note 130, at 46; see also Dillon, supra note 155, at 55 (describing increased systemization displayed in fourteenth century compilations); Stevens, supra note 174, at 363 (stating that more than 2,100 trouvère poems and at least 1,400 melodies are known today).

199. See RAYNOR, supra note 130, at 46. On one view, "[u]ntil the end of the thirteenth century, the biographies and even the names of musicians were of no interest to anyone." CHAILLEY, supra note 25, at 12; Grout \& PALISCA, supra note 46, at 87-88 (naming Petrus de Cruce as "one of the few identifiable thirteenthcentury composers"); Edwards, supra note 130, at 33 (discussing an anthology of poetry meant to be sung in which the authors of most poems were anonymous). That statement overstates the case because we find the fourteenth-century compilers of the chansonniers using composer identity as an organizing principle, in part to give the reader additional information about the social status of the "I" who suffers the pangs of unrequited love in the lyric. See DiLLON, supra note 155, at 55 \& nn.81-82 ("Author conventions also play a central role in the [compilers'] refashioning of the songs."); see also id. at 68 (compilers' ascribing of authorship to composers may have indicated a view that the text was connected to the biographical facts of its maker, but "these extratextual/musical personalities may be better read as poetic gestures: they assemble the author as a fictive extension of the songs, the life of the troubadour ... painted so as to mirror ... the lyric 'je' of the poetry.").

200. See, e.g., Edwards, supra note 130, at 30 (identifying a melody written by the Comtessa de Dia); Stevens, supra note 174, at 373-80 (analyzing songs by known troubadours). 
notion of a moral right of attribution appears to have accompanied medieval composition. Rather, the compilers of chansonniers identified composers for taxonomical and archival reasons rather than as recognition of the musical works as part of the composers' estates. ${ }^{201}$

Guild members also composed polyphonic music, and competition with itinerant musicians led some guild members to seek control not only of musical labor but the music itself. The incentive for guild composition came from endowments by members of the confraternities and guilds. ${ }^{202}$ Some of these composers began to make proprietary claims in the late Middle Ages and early Renaissance, but these claims did not become commonplace and were not vindicated by law. Traditionally, jongleurs freely borrowed and revised popular melodies and songs composed by others. ${ }^{203}$ As guild membership supplied musicians with increased economic security and a professional identity, some developed the ambition to be known as the creators of their songs and complained of the use that itinerants put to works they created. ${ }^{204}$ However, these complaints about lack of control did not appear to have wider circulation. As the motet form emerged, during the twelfth to fourteenth centuries, "[c]omposers and performers freely used and altered a common stock of motet melodies, both tenors and upper parts, indeed any music known to them, without acknowledgment."205

201. See DiLlon, supra note 155 , at 55 ("The books are in this way fashioned . . . as mausoleums—-shrines to a desired historical past.”).

202. See WILSON, supra note 162, at 1 (remarking on musicologists' surprise to learn of non-aristocratic patronage).

203. See, e.g., Grout \& PALISCA, supra note 46, at 58 (describing how minstrels "sang, played, and danced to songs composed by others or taken from the popular repertory, no doubt altering them or making up their own versions as they went along").

204. See RAYNOR, supra note 130, at 47-48 ("A contemporary of Chaucer ... complains bitterly of the use made by itinerants of the works of others and, although the notion of music or poetry as its creator's intellectual property was new, describes the piracy of the traveling entertainers as a new and ominous sign of a decadent age."). Raynor's anachronistic use of "intellectual property" and "piracy" to contextualize Chaucer's contemporary's complaint violates the principle of hermeneutic modesty. First, it is not clear that the complaint even counts as a proprietary claim for purposes of this study because the musician may seek nothing more than attribution. Assuming the claim is for a right to control public performance, the claim is interesting insofar as it anticipates by more than 500 years claims that copyright law eventually will vindicate. This is interesting for it signals a subject, a "composer," relating to his compositions, almost certainly variations on a set of wellestablished themes and conventions, as distinct and personal objects susceptible to proprietary claims. However, complaints about unauthorized public performance would be one of the last proprietary claims to be vindicated by law, and it is more than a stretch to use this anecdote as the basis for claiming that the concept of "intellectual property" had any meaning in Western Europe or that unauthorized public performance could be "piracy"- a claim not even supported during most of the period of music publishing in which "piracy" was used solely in relation to unauthorized publication.

205. Grout \& PALISCA, supra note 46, at 85; see also Peraino, supra note 160, at 659 (arguing that medieval monophonic motets taken from polyphonic compositions were "independent samples or samplelike melodies that strategically reference or engage musical repertories"). 


\section{Summary}

Proprietary claims in relation to music were first made and vindicated during the Middle Ages. Musicians' guilds had the exclusive right to perform music within the city walls during a time when written music was not in widespread use. Musical repertories were accessible only through musicians, and by controlling who could act as a musician within the city, the law gave the guilds a kind of proprietary control over music itself. Other potential claimants apparently did not make proprietary claims in relation to music with any regularity. Some evidence indicates that guild members composed music and considered use of that music by itinerant musicians to be wrongful, but we have no evidence that this view was widespread or that it was vindicated by law. On the contrary, composers freely borrowed from one another during the period.

Two developments created the preconditions for copyright: the development of musical notation and the emergence of the composer. Musical notation was developed as a tool of control by the Church, which sought to create and fix authoritative musical texts. The tool, however, facilitated development and transmission of complex, polyphonic music against the Church's stated desire. The development of notation facilitated the objectification of music, which, in turn, facilitated its commodification. As notation developed, the act of composing music became more clearly a distinct practice, giving rise to the social role of "the composer" occupied by those who engaged in the practice. In northern France, composers of sacred music emerged to occupy the role, while in southern France, the troubadours gave birth to the singer-songwriter tradition. While neither group made proprietary claims concerning others' use of their music, their self-awareness as creators of new art, Ars Nova, for example, laid the groundwork for the subsequent proprietary claims vindicated by copyright law.

\section{The Renaissance}

It was during the Renaissance that the concept and practice of treating music as a form of property really emerge. Initially, proprietary claims were made by music publishers with respect to musical texts they brought to market. The law vindicated these claims on an ad hoc basis in the form of royal privileges granting the holder the exclusive right to publish a certain work or class of works. ${ }^{206}$ Meanwhile, the development of 
humanist conceptions combined with commercial arrangements in the publishing trade led composers to become increasingly self-aware subjects, capable of conceiving of the music they created as theirs. The pioneer in this respect was the Flemish composer Orlando Lassus, who received privileges in France and Burgundy to control the printing of his music. The increased capacity of composers to claim rights in their music, however, was but a step toward the development of copyright in music. It would take almost two hundred years after the Renaissance for the law to shift the vindication of proprietary claims from the publisher's privilege to composer's copyright and more than another century before the law would extend the reach of proprietary rights in music to public performance.

Although full-blown commodification of music would have to await copyright, the elements of modern property claims in music began to take discernable shape beginning in the fifteenth century ${ }^{207}$ and the process accelerated with the arrival of the printing press in $1440 .{ }^{208}$ This section first turns to the birth of the music publishing industry. Music publishing was a risky and expensive business. Publishers sought property-like protections from the political authorities to reduce the risks posed by potential competitors. The wider circulation of published music gave tangible form to musical expression, making the property claims of publishers in the intangible music conceptually more plausible and acceptable. Property claims during this period remained limited to rights to publish and vend copies of musical scores. In some places, the rights

207. See RAYNOR, supra note 130, at 86. Raynor appears to regard this period of patronage as the point of commodification for music, although he does so by attributing to the nobility a culture of conspicuous consumption in which this new "property" deliberately was wasted. Contrasting the Church's proprietary claims with those of Renaissance patrons, Raynor writes:

$[\mathrm{W}]$ hat was written for the church, and what the church had therefore purchased, was not individual property to be casually disposed of .... Secular music was written simply for a specific occasion, usually in the latest style, and then forgotten; it was the property of a Sforza, a Gonzaga, a Medici, a d'Este, men whose wealth existed to be squandered in the cause of impressing the world and maintaining a reputation for grandeur.

Id. (emphasis added).

Raynor appears to conflate property claims in the tangible manuscript and in the intangible musical work. Even if we grant that Renaissance patrons considered the manuscripts to be their property rather than that of the composers, that claim does not necessarily signal a claim to control reproductions or performances of the music embodied in such manuscripts. It does appear as if patrons did so regard the output of "their" composers. See Howard Mayer Brown \& Louise K. Stein, Music in the Renaissance 107 (2d ed. 1999) (describing 1473 letter from Duke of Milan, Galeazzo Maria Sforza, to Josquin des Prez, a famous polyphonic innovator, as reflecting that "[a]s was usual in the relationship between patron and musician in this period, the duke asked for absolute fidelity and considered Josquin's labor (whether as composer or music copyist) and his music his property"). Nonetheless, the treatment of music composed for secular occasions as ephemeral appears to reflect a continuation of longstanding tradition.

208. Gutenberg completed his wooden press which used metal moving type in 1440 . It was not until 1455 that he finished work on his 42 Line Bible. 
were limited to reproduction of an entire compilation rather than its constituent elements. Claims against unauthorized public performance were not cognizable.

This section then discusses the concomitant developments through which composers began to make more consistent claims for attribution and, in some cases, control in connection with their musical works.

\section{Overview}

The term "Renaissance" (i.e., "rebirth") was coined by nineteenthcentury European historians, and generally is used today to describe the period roughly from 1450-1600 C.E. Certainly, rapid developments in trade, science, technology, philosophy, and the arts took place during this period. ${ }^{209}$ But the image of rejuvenation the term conjures underemphasizes certain continuities, such as the process of late-medieval urbanization, and glosses over discontinuities in the development of humanist thought and action. Moreover, emphasis on scientific and cultural developments implies a period of peaceful evolution, but in fact Western Europe during this time experienced considerable political instability with nearly routine episodes of armed conflict and widespread outbreaks of fatal disease. With that caveat, we proceed to evaluate the developments through which music first became commodified during this period.

As a reminder, the economic base for social and political relations during the Renaissance was the markedly increased mercantile activity within Europe and between Europe and the rest of the world known to or "discovered" by Europeans. ${ }^{210}$ The profits from trade flowed toward political authority, which increasingly came to reside in the growing urban centers. ${ }^{211}$ Remnants of the feudal aristocracies, successful merchants, and their political allies accumulated significant capital. That capital went to finance a number of ventures, such as exploration for new markets, traffic in human beings, and competition with other urban centers in the fields of arts and education. ${ }^{212}$ Absent from the account that follows are the tales

\footnotetext{
209. See, e.g., THE RENAISSANCE: From the 1470s TO THE END OF 16TH CENTURY 379-93 (Iain Fenlon ed., 1989) [hereinafter THE RENAISSANCE] (providing helpful, though necessarily selective, chronology of these developments).

210. See, e.g., Iain Fenlon, Music and Society, in THE RENAISSANCE, supra note 209, at 36 ("By the end of the fifteenth century great trading communities had established themselves throughout Europe.”).

211. See, e.g., Michael Chanan, Musica Practica: The Social Practice Of Western Music From GREGORIAN CHANT TO POSTMODERNISM 65 (1994) (describing end of feudalism and benefits of urbanization for music production).

212. See, e.g., Tim Carter, Music In Late RenaissanCE \& EARLy BAROQUE ITALy 33 (1992) (describing how economic structure and growth in Renaissance Italian city-states gave aristocracy and rising bourgeoisie
} 
of armed aggression within and outside of Europe as well as any of the details surrounding the political intrigues of the Renaissance courts. Instead, our focus is on how the commodification of music grew from mercantile psychology ${ }^{213}$ and social relations combined with increased capital expenditures on music production and dissemination.

In the fifteenth century, considerable political power remained in northern Europe in the Duchy of Burgundy, which covered parts of what today are the Netherlands, Belgium, France, and Luxembourg. ${ }^{214}$ At the same time, the urban republics in what is now Italy were at the center of a number of trade networks, which gave them an advantage in capital accumulation. ${ }^{215}$ Italy receives most of the attention, notwithstanding the role played by the great maritime powers in Spain, Portugal, and, later, England and the Netherlands, because the Church remained the principal employer of composers and musicians throughout the period. Moreover, competition for musical talent created a cultural aesthetic favoring innovation and spectacle. This competition led to a certain cosmopolitanism in both Burgundy and Italy, and talented composers of the day crossed the Alps to partake in developments in both places. ${ }^{216}$

disposable income that could be "devoted to conspicuous private consumption in the arts"); GROUT \& PALISCA, supra note 46, at 150 (describing economic base for Renaissance).

213. I use "mercantile psychology" to refer to a mindset through which one views the objects around one as commodities to be traded in markets to yield potential profits. The mercantile mindset grew out of economic relations determined by guild structure. Notwithstanding the picture of "Renaissance man" as a broadly educated citizen of the world-a picture appropriate for certain members of the elites-the mercantile psychology was fueled by an educational system among the classes conducting trade that focused on the accounting and other skills necessary for running a successful business. See, e.g., WILSON, supra note 162, at 1113 (describing the "arithmetical mentality" prevalent in fourteenth century Florence and the educational requirements focused on developing quantitative skills).

Blake Wilson's study of the laudesi companies in late medieval/early Renaissance Florence illustrates the roots of the mercantile mindset. Consider this description of how Dominican and Franciscan friars appealed to the mercantile classes:

The friars frequently enlisted commercial and political imagery. In the 'workshop of your conscience[,]' . . . the merchant is to regard Christ as a bonus negotiator, and to prefer heavenly to earthly riches. Lent, like a great trade-fair, is a good time for making a profit, because spiritual money-changers . . . are ready to hear confessions, during which the sinner may profitably exchange base money (sin) for precious money (grace). There is an excellent display of the goods (the preaching is frequent), and money is available (vigils, prayer, and fasts, with which the kingdom of heaven is bought). The sinner who dies unrepentant is like the debtor who forfeits in perpetuity his security (his soul) to the usurer (the devil), if he fails to buy it back before the end of the trade-fair (death).

Id. at 25 (footnotes omitted).

214. See, e.g., Fenlon, supra note 210, at 16-17 (describing Duchy of Burgundy as dominant power in Europe).

215. See CHANAN, supra note 211, at 65 (describing economic prosperity of Italian city-states); IAIN Fenlon, Music, Print and Culture in Early Sixteenth-Century Italy 15, $59-60$ (1994) (same, especially Venice).

216. See, e.g., BROWN \& STEIN, supra note 207, at 23-25 (describing Italy as "extraordinarily generous in fostering composers" but crediting Burgundy as the center of musical training in fifteenth-century Europe); 
The ruling classes in the Italian republics spent lavishly on artistic production, rewarding not only production but also innovation. Talented composers and performers flocked to the Italian courts for the material and intellectual opportunities available there. ${ }^{217}$ Musicians from northern Europe, who had produced principally religious music, increasingly were directed by their Italian patrons to compose and perform music for civic ceremonies and for Carnival. ${ }^{218}$ Each occasion demanded its own composition. Demand intensified to the point that some musicians were employed solely as composers. ${ }^{219}$ Much of this music was not published and the original manuscripts are not available. ${ }^{220}$ Within this group of unpublished music is that composed for Carnival, celebrated with renowned gusto in late fifteenth-century Florence under Lorenzo de' Medici. ${ }^{221}$ Some of the Carnival music apparently communicated political or social satire, ${ }^{222}$ while in other cases we see the predecessor of the advertising jingle as trade guilds "promoted their products in tuneful verses sung from elaborate floats" during Florentine holiday celebrations. ${ }^{223}$

\section{Music Publishing}

As both conceptual and economic matters, the legal treatment of music as a form of property is most closely linked with the development of markets for published music. ${ }^{224}$ Following Gutenberg's development of the printing press, music publishing began to take hold in the latter fifteenth century. Music publishing was more involved and more expen-

Fenlon, supra note 210, at 18 (at Burgundian court, "[t]his extraordinary cosmopolitan concentration of power and skills created an atmosphere in which artists, musicians and men of letters and science were able to practise their talents to an extent that was unusual in the highly stratified societies of fifteenth-century Europe."); see also Evelyn Lincoln, Invention and Authorship in Early Modern Italian Visual Culture, 52 DePAUL L. REv. 1093, 10991100, 1103 (2003) (describing advantages of working at court for visual artists).

217. See, e.g., BROWN \& STEIN, supra note 207, at 82 (describing domination of Italian courts by northern musicians from across the Alps, known as oltremontani).

218. See, e.g., RAYNOR, supra note 130, at 83-86 (describing influx of northern musicians into Italian cities and support for secular music).

219. For example, Heinrich Isaac, who began his career as a musician in the employ of Lorenzo de Medici, was subsequently employed by Emperor Maximilian as court composer under what we might today call a requirements contract. See id. at 78-79. Isaac was permitted to live where he chose (rather than at court) and supplement his income as he chose so long as he supplied the court choir with new compositions as and when they were required. See id.; BROWN \& STEIN, supra note 207, at 146; Martin Picker, The Habsburg Courts in the Netherlands and Austria, 1477-1530, in THE RENAISSANCE, supra note 209, at 234.

220. See, e.g., RAYNOR, supra note 130, at 85 (describing the absence of manuscripts of Isaac's secular but not religious compositions).

221. See BROWN \& STEIN, supra note 207, at 94 (describing festivities).

222. See id.

223. GROUT \& PALISCA, supra note 46 , at 170.

224. See, e.g. CHANAN, supra note 211 , at 112 ("Music as a commodity is younger than literature, and it was printing that made it an object of commerce."). 
sive than book publishing. ${ }^{225}$ During the first decades, publishers printed monophonic, religious music because the market was better defined. ${ }^{226}$

By the start of the sixteenth century, Italy had become the center of the fledgling music publishing business and the northern cities, particularly Venice, would remain central for most of the remainder of the Renaissance. In 1501, Ottaviano de' Petrucci, a Venetian publisher, began to significantly publish works other than plainsong. ${ }^{227}$ Following Petrucci's success, the Venice-based Scotto Press, established in 1539, became a very successful international music publisher and distributor.

Book publishing had begun to flourish in other parts of Europe as an outgrowth of existing medieval trade in hand-copied manuscripts. ${ }^{228}$ Music publishing, however, did not develop in earnest elsewhere in Europe until about 1530, when print technology improved and demand for printed music increased. ${ }^{229}$ Initially, printers using movable type employed a triple-impression and then a double-impression technique by which the staff was first printed followed by the notes. In 1520, London publisher John Ratsell developed a single-impression technique, which was first practiced on a large scale by Parisian publisher Pierre Attaingnant. ${ }^{230}$ He used this technique to publish the first polyphonic chansons in France

225. Publishers faced the challenges of representing short musical examples in theoretic works, monophonic Gregorian chant, and polyphonic music. Printers experimented with wood blocks, metal blocks, and movable type to represent the staff, notes, and lyrics. See id. at 112-13.

226. The first known book meant to include music is the Psalterium, printed by Gutenberg's associates in Mainz in 1457, and the first known instance of music printing with movable type is Michael Zarotus of Parma's Missale, completed at Milan in 1476. See Gustave ReESe, Music In the Renaissance 154 (rev. ed. 1959); Music Printing in Britain Through 1695, available at http://www.hoasm.org/IVM/MusicPrinting .html (last visited Feb. 14, 2004). Of the estimated 30,000 incunabula (books published prior to 1501), about 270 contain printed notes and staves. See Mary Kay Duggan, Music in the Fiffeenth-Century Printed Missal, in The DisseminAtion of Music: Studies in the History of Music Publishing 1 (Hans Lenneberg ed., 1994) [hereinafter Dissemination OF MUSIC].

227. See REESE, supra note 226, at 155; FENLON, supra note 215, at 2. By 1523 he had published fifty-nine volumes (including reprints) of vocal and instrumental music. See GrouT \& PALISCA, supra note 46, at 151 (describing development of music printing).

228. See, e.g., Daniel Heartz, Pierre Attaingnant: Royal Printer of Music 14-15 (describing market in Paris for manuscripts and for paper prior to printing); CHANAN, supra note 211, at 112 (contrasting Middle Ages market for literary manuscripts with absence of similar market for musical manuscripts). Of course, music had circulated in manuscript form, and continued to do so throughout the Renaissance, but trade was much less developed than in the literary sector. See, e.g., Richard Freedman, Paris and the French Court Under Francois I, in THE RENAISSANCE, supra note 209, at 187-88 (describing circulation of French manuscripts in sixteenth century).

229. See generally Jane A. Bernstein, Print Culture and Music in Sixteenth-Century Venice (2001).

230. Some debate surrounds the date of the first single-impression music printing. See Chanan, supra note 211, at 113 (mentioning sources claiming dates of 1507, 1512, and 1525). However, most sources appear to credit Ratsell as the inventor. See, e.g., Grout \& PALISCA, supra note 46, at 152 (describing development of printing techniques); FENLON, supra note 215, at 47; BERNSTEIN, supra note 229, at 21. Early examples of engraving date to the early sixteenth century, but engraving would not displace printing until about 1700 . See A. Hyatt King, Four Hundred Years of Music Printing 16-17 (2d ed. 1968). 
in $1528,{ }^{231}$ and it soon spread across Europe. ${ }^{232}$

The spread of single-impression printing led to a marked decline in the price for printed music, making the music increasingly accessible to middle-class buyers. ${ }^{233}$ The initial secular offerings were collections of chansons, but as the sixteenth century progressed, the madrigal became all the rage. ${ }^{234}$ Development of the madrigal form, in which as many as six independent "voices" 235 were combined, changed the uses of physical musical texts. Publishers adapted the texts to the new uses by exchanging the choir book format, in which all voices were represented together, for the "partbook," which gave the music for a single voice intended to be performed as part of a polyphonic piece. ${ }^{236}$

\section{a. The Law of Music Publishing}

The legal framework developed to regulate printed matter in general also applied to music publishers, although music publishing was regarded as a less remunerative and more complicated specialty within the trade. Increasing literacy throughout Europe made publishing a more lucrative undertaking, leading some publishers and printers to petition for economic protection from competition. ${ }^{237}$ At the same time, Church authorities and aristocrats were faced with the Reformation and were eager to suppress Protestant expression. ${ }^{238}$ Responding to these constituencies, the law throughout Europe came to grant limited monopolies in expressive and technological innovation and to impose content controls through licensing and guild control of publishing and printing. Although analytically distinct,

231. REESE, supra note 226, at 290. Over his career he published about seventy compilations containing almost 2,000 chansons. See id.; Yvonne Rokseth, The Instrumental Music of the Middle Ages and Early Sixteenth Century, in 3 New OXFORD HisTORY, supra note 115, at 406, 450 (describing Attaingnant's early releases). Some of the early instrumental music for keyboard that he published did not identify the composer. Id. at 449.

232. One of the earliest examples of music publishing in England is a 1530 collection of works by Robert Fayrfax. REESE, supra note 226, at 768. "Music printing began in Germany about 1534 and in the Netherlands in 1538." GROUT \& PALISCA, supra note 46, at 152. In Antwerp, a well known printer established himself in 1529, followed by the partners Hubert Waelrant, a composer, and Jean Laet, a printer, who established a successful publishing house in 1554. REESE, supra note 226, at 290; see also ROBERT LEE WEAVER, WAELRANT AND LaET: Music Publishers in ANTWERP’s Golden Age, at xx (J. Bunker Clark ed., 1995).

233. See FENLON, supra note 215, at 85-88 (describing growth of the market).

234. See, e.g., James Haar, Orlando di Lasso, Composer and Print Entrepreneur, in Music AND THE Cultures OF Print 125, 129 (Kate Van Orden ed., 2000) [hereinafter Cultures OF Print] (Venice publishers concentrated secular offerings on the madrigal).

235. A "voice" refers to an independent melodic line that could be performed either with a human voice or another musical instrument.

236. See FENLON, supra note 215, at 20-21 (change from choir book to partbook), 50 (Attaingnant's partbooks set the standard).

237. See, e.g., RANSOM, supra note 16 , at 28-29.

238. See Patterson, supra note 16, at 20-27. 
the monopoly and censorship functions of law often were administratively linked. ${ }^{239}$

The legal device for granting exclusive rights in expressive or technological innovation was the royal privilege or "letter patent." 440 The rights granted by a privilege or patent had property-like features in that they could supply the basis for a claim against unauthorized competition, but the government was free to revoke the privilege or grant overlapping rights to another party any time. ${ }^{241}$ Petitions for publishing or printing privileges frequently were phrased in the language of incentives in light of the particular risks involved in publishing, but European monarchs used the privilege or patent to grant monopolies over a wide range of economic activities for which no plausible inventive rationale could be or was advanced. ${ }^{242}$

Historians of intellectual property law generally cite privileges granted by the Italian republics of Florence and Venice in the early fifteenth century as the first technological patents in the modern sense of the word. ${ }^{243}$ To lure technological innovators to northern Italy, the Venetian Senate adopted in 1474 what some consider to be the first patent statute. ${ }^{244}$ Copyright-like privileges followed later. The first copyright-like privilege granting control over the printing of a specific book was granted in 1479 in Germany, followed by a similar privilege granted in 1486 in Venice. ${ }^{245}$

239. See id. at 87. I thank Oren Bracha for his clarifying comments in this regard.

240. The letter "patent" was a form of privilege granted in England. As Edward Walterscheid explains: The kings [and queens] of England did much of their state business by means of charters, letters patent, and letters close. At least initially, charters were used for their more solemn acts. Letters patent were used to set forth their public directives, of whatever sort, whereas letters close were used to provide private instructions to individuals. Royal charters and letters patent often were similar in content and differed only in their form.

Edward C. Walterscheid, The Early Evolution of the United States Patent Law: Antecedents (Part I), 76 J. PAT. \& TRADEMARK OfF. SOC’Y 697, 700 (1994) (internal citation omitted); see also RANSOM, supra note 16, at 25-27 ("As time went on, the distinction between the printing privilege granted by warrant and the rights conveyed by letters patent became indistinct.”). Letters patent were open to public inspection. Walterscheid, supra, at 701 .

241. See, e.g., PATTERSON, supra note 16, at 79 ("Since the patent was granted at the will of the sovereign, probably none of the provisions was invariable."); Bracha, supra note 12, ch. II at 18-19 (exclusive right to print was not conceived of as broader property right in intangible work).

242. In England, abuse of the crown's power to grant monopolies on the sale of industrial inputs, such as iron and steel, and food items, such as vinegar, would eventually lead to the Statute of Monopolies, which restricted the crown's privilege-granting power. See PATTERSON, supra note 16, at $83 \&$ n.23. Privileges for technological and expressive innovation were allowed and for this reason, we now look at the royal privilege primarily as the antecedent of modern patent and copyright law.

243. See, e.g. BugBEE, supra note 48, at 15-25; Walterscheid, supra note 240, at 705-06; see also John F. Duffy, Harmony and Diversity in Global Patent Law, 17 BerKeLEY TECH. L.J. 685, 710-12 (2002).

244. See BugBEE, supra note 48 , at 22-23 \& n.61 (quoting statute). Exclusive rights in inventions still had to be obtained case-by-case, but the statute stated a general policy for the novelty, utility, and enablement requirements for a successful petition.

245. See Elizabeth Armstrong, Before Copyright: The French Book Privilege System 14981526, at 2-4 (1990). During the Counter-Reformation, the Council of Ten passed a copyright-like, author- 
In England, the printing press arrived in $1476,{ }^{246}$ Henry VII appointed a royal printer in $1485,{ }^{247}$ and the first printing privilege was granted in $1518 .^{248}$ Privileges were granted sparingly during the first half of the sixteenth century. ${ }^{249}$ During the latter half of the century, privileges over classes of works or individual works coexisted with a more general charter granted to the Company of Stationers who collectively had the exclusive rights to publish works not subject to a royal privilege.

In the music publishing field, legal protection was granted to encourage two lines of innovation: increased expressive productivity to feed a developing market for printed music and increased technological innovation to make production of printed music cheaper and faster. As a copyright predecessor, the privilege granted exclusive rights to publish and sell copies of music for limited times in geographically limited areas —often only within a city. ${ }^{250}$ The privilege generally belonged to the publisher. ${ }^{251}$ To the extent that the privilege system established prototype property rights, the publisher owned the right to reproduce the musical composition in printed form, while the composer had a right only in the original manuscript. ${ }^{252}$ In the music printing field, the patent-like privileges granted exclusive rights to print music using a specific technique or specific type of font. ${ }^{253}$ Because printers had to develop new fonts to keep up with improvements in notation, privileges to print certain works, or works in certain languages, also gave some protection to the technological innovation as well as the musical work. ${ }^{254}$ But the most economically

accountability provision requiring that any book to be published in Venice must be done with written permission from the author and submitted to the Commissioners of the University of Padua-the state censors. See BugBeE, supra note 48 , at 46.

246. See Patterson, supra note 16, at 20.

247. Id. at 81 .

248. Id. at 42 .

249. For examples of early privileges, see BUGBEE, supra note 48, at 49-50.

250. See, e.g., HEARTZ, supra note 228, at 146-47 (describing how works protected by privilege within Paris were freely republished in Lyons).

251. Some publishers also were composers. In addition, we know some composers acquired the privilege and hired printers to print their music. See, e.g., FENLON, supra note 215, at 35.

252. See RANSOM, supra note 16, at 34 (stating that in the world of book publishing, during the Elizabethan era, "[e]xtent of sale had nothing to do with an author's earnings ...; after final disposition of manuscript, his only additional income depended upon his bookseller's generosity"); D.W. KRUMMEL, ENGLISH Music PriNTING: 1553-1700, at 10 (1975) (stating that unless composer was a grantee or a stationer, he had no rights to control or profit from publication); see also ATTALI, supra note 169, at 52-53.

253. See, e.g., BERNSTEIN, supra note 229, at 21 (citing a privilege granted "to print or have printed both music and tablature with characters of tin or of other mixture”); Duggan, supra note 226, at 12 (describing Petrucci's original 1498 privilege as covering methods of printing and stating that "[a] monopoly system to protect types as well as titles contributes to centralized control of music publication and distribution, and it was already in place in the fifteenth century.").

254. See, e.g., BERNSTEIN, supra note 229, at 17-21 (describing print specialization and attendant privileges). Consider, for example, the following Venetian petition in the early sixteenth century: 
significant innovation was single-impression printing. ${ }^{255}$ For those interested in the relationship between legal control over technology and innovation, note that the critical technological development of singleimpression printing was developed and spread outside the limited forms of legal control available. ${ }^{256}$

The censorship function of licensing requirements frequently was bundled with monopolization function of the privilege. As a form of printed matter, music also became subject to the licensing requirements in places such as England, Burgundy, and, later, in France. ${ }^{257}$ In Italian cities other than Rome, privileges were optional and often were bestowed by the republican government, such as the Venetian Senate. ${ }^{258}$ In Paris, the privilege initially was optional, as evidenced by the fact that Attaingnant did not obtain one for his first publications. ${ }^{259}$ However, he subsequently received a most significant privilege designating him the printer of the King's music. ${ }^{260}$ Privileges became mandatory in France in 1566, when their function as protection from competition merged with the function of a license to print. ${ }^{261}$

The legal developments in England differed from those on the

Jacomo Ungaro, cutter of letters[,] . . . having discovered the way to print measured music, and fearing that others, as happens, may reap the fruit of his labors, begs your Excellency that you be pleased to grant him the favor that no one else may print or have printed the said measured music either in this city or in its provinces for the next fifteen years, nor bring books printed elsewhere to sell in this city or subordinate lands, under penalty of losing all the books and 100 ducats for every time that it occurs.

Duggan, supra note 226, at 11 (citation omitted). As with other developments discussed supra, this petition anticipates numerous facets of subsequently enacted statutory protection of intellectual property, including a limited term, exclusive rights within a geographical area regardless of the source of infringing materials, a right to destroy infringing materials, and a right to receive liquidated damages.

255. Musicologists generally credit the development of single-impression printing, which became less labor-intensive over time, as the springboard that increased productivity, allowing publishers to reduce price and reach the emerging middle class market for printed music. See, e.g., FENLON, supra note 215, at 47 (singleimpression printing "gradually was to revolutionise the economics of the music trade"); BERNSTEIN, supra note 229, at 21-22 ("By using the single-impression method, Attaingnant propelled music printing into a moneymaking enterprise."); HEARTZ, supra note 228, at 107-08 (Attaingnant and Antico were able to offer printed music much cheaper than had Petrucci); Haar, supra note 234, at 128-29 (single-impression printing "put Italian music printing on a solid commercial basis").

256. See, e.g., FENLON, supra note 215, at 53 (“Attaingnant's single-impression methods were quickly copied."). Recall that Attaingnant did not invent the method but was the first to demonstrate its economic advantages. See supra note 230 and accompanying text.

257. By contrast, in the Netherlands, Charles $\mathrm{V}$ had instituted the privilege system in 1520 . WEAVER, supra note 232, at 252. Publishers, including music publishers, were required to obtain a privilege and theological approval before printing. The privilege system secured for the government both a source of revenue and, more importantly, a means of religious and political control. Id. at 251-52.

258. Jane A. Bernstein, Music Printing in Renaissance Venice: The Scotto Press (1539-1572) 17 (1998).

259. See HEARTZ, supra note 228 , at 77.

260. See id. at 87-90 (describing Attaingnant's privilege).

261. See ARMSTRONG, supra note 245, at 100. 
Continent because of the centralization of control over most publishing by the Company of Stationers. Although England did not become a real center for music publishing until the late sixteenth, or early seventeenth, century, American copyright law derives from English practice and so we begin there.

\section{i. England}

Within the legal literature, the story of book publishing in England has been told many times. ${ }^{262}$ The development of music publishing has been given considerably less attention. Music publishing's development generally tracked that of book publishing, except the competitive pressures were somewhat less because the potential prizes to be won in the market were smaller.

For example, in England, the arrival of the printing press was generally welcomed by those in power, and foreign printers were encouraged to relocate to spur the growth of the publishing trade. ${ }^{263}$

During the 1530s, the regulation of the publishing and printing trades increased in response to Henry VIII's split with Rome and domestic printers' agitation over book production by resident foreign printers and importation of English texts. A series of censorial proclamations led to the 1538 establishment of a general licensing scheme under which all English books printed abroad were banned and no English books could be printed without prior approval of a King's representative. ${ }^{264}$ This was followed by subsequent decrees, proclamations, and statutes roughly to the same effect. $^{265}$ Responding to complaints of foreign competition,

262. See generally, e.g., ROSE, supra note 16; PATTERSON, supra note 16, at 63-74; KAPLAN, supra note 16; Ransom, supra note 16; see also John Feather, A History of British Publishing (1988); DAvid SAUNDERS, AUTHORSHIP AND COPYRIGHT (1992); Bracha, supra note 12.

263. See PATteRson, supra note 16, at 22; RANSOM, supra note 16, at 21-23.

264. See Patterson, supra note 16, at 22-23.

265. In 1546, Henry VIII ordered that no printer shall print any manner of English book, ballad, or play, unless he puts his name along with the name of the author and day of print. W. W. Greg, Some Aspects and Problems of London Publishing between 1550 and 16502 (1956). In London, beginning in 1549, and continuing through 1553, the Privy Council offered a series of proclamations that essentially forbade anyone "to print any books, matter, ballad, rime, interlude, process, or treatise, nor to play any interlude" unless they had a special license in writing from the crown. Id. at 2-3. The Privy Council was the chief source of executive power in England before the emergence of the cabinet system of government. It developed during the later years of the reign of Henry VIII (1509-1547), when the councillors at the King's side became permanently organized as a "privy council." Under the later Stuarts the Council declined in power due to the Stuart policy of working primarily with confidential committees within the council. Following the repeal in 1706 of the clause in the Act of Settlement (1701) which would have compelled all business to pass through the full Privy Council, it rapidly lost its political powers to the Cabinet.

In the Injunctions of 1559, Queen Elizabeth grouped published music together with published books when she said that "because many pamphlets, plays, and ballads be oftentimes printed[,] ... her majesty likewise 
Parliament enacted statutes in 1533 under which imported books also were banned and price controls were placed on booksellers. ${ }^{266}$

In 1557, the trade regulation and censorship functions of law largely were integrated in the grant of a charter to the publishing guild, the Company of Stationers. ${ }^{267}$ Trade regulation remained complicated. To exercise their collective near-monopoly on printing, the Stationers developed a perpetual right in copies administered through a registration scheme and accompanied by its own enforcement mechanisms, ${ }^{268}$ which regulated publishing rights inter se. ${ }^{269}$ But the crown had not relinquished its prerogative to grant exclusive privileges to print, and many of the most lucrative works or classes of works were subject to control under a royal grant. ${ }^{270}$ Such a grant might be awarded either to a member of the Company or to a non-member who would rely on a Stationer for the printing. Works protected by special grant usually were not entered in the Company's registers, but the Stationers were nonetheless obliged to avoid infringement of the rights granted in such privileges. ${ }^{271}$

Indeed, when the scope of a privilege conflicted with a Stationer's right in a copy, the privilege prevailed. ${ }^{272}$ These privileges often were concentrated in the hands of a few powerful members of the trade, which gave them greater leverage within the Company. ${ }^{273}$ Less powerful members of the Company particularly resented these privileges because they often covered reference books without a discernable author that would have been a kind of limited commons property ${ }^{274}$-non-members would have been excluded from printing these works but within the Company the

commands that no manner of person shall enterprise to print any such, except [if] licensed by such her majesty's commissioners." The Injunctions of 1559, in DOCUMENTS ILLUSTRATIVE OF ENGLISH CHURCH HISTORY 436-437 (Henry Gee and W. H. Hardy eds., 1896), available at http://history.hanover. edu/texts/ENGref/er78.htm.

266. See PATTERSON, supra note 16, at 22-23.

267. See id. at 29, 32 ('[T] he charter of the Stationers' Company gave it an almost complete monopoly of printing, together with the powers of national regulation.”). Moreover, the Stationers' Company was empowered to "take away, have, burn, or convert to their own use whatever they should think was contrary to the form of any statute, act, or proclamation made or to be made." RANSOM, supra note 16, at 29.

268. See, e.g., PATterson, supra note 16, at 57; Masterson, supra note 43, at 628-29; Joseph KeRMAN, THE ElizABETHAN MADRIgAL 260 (1962) (describing case of Thomas Vautrollier, a Brother of the Stationers' Company, who in 1578, and again in 1579, was fined for printing Luther's Commentary on Galatians and whose unauthorized publication in 1584 of Bruno's Last Trump was a serious enough offense that it caused him to flee Scotland).

269. See PATtERSON, supra note 16, at 63-74 (describing internal working of Stationers' Company and means by which a Company member came to be the owner of "copy" in a manuscript).

270. See, e.g., PATTERSON, supra note 16, at 90-91; Bracha, supra note 12, ch. II at 14-19.

271. KRUMMEL, supra note 252, at 10.

272. See, e.g., PATTERSON, supra note 16, at 78-79.

273. See, e.g., PATTERSON, supra note 16, at 90-91; Bracha, supra note 12, ch. II at 14-19.

274. See Carol M. Rose, The Several Futures of Property: Of Cyberspace, Folk Tales, Emission Trades and Ecosystems, 83 MinN. L. REv. 129, 139-43 (1998) (defining and describing limited commons property regimes). 
works would be a common resource available to all to print. ${ }^{275}$

Music was not a lucrative subject matter for publishers, but it remained largely subject to royal printing patents rather than the Stationers' monopoly. ${ }^{276}$ Although limited in time, these privileges had two important property-like characteristics. First, they gave the holder the exclusive right to make and sell music's written expression. Second, that exclusive right was transferable during the life of the privilege. ${ }^{277}$

Some evidence supports how effective regulation by printing patent was. When privileges owned by music publishers expired, a number of musical publications appeared before the grant and enforcement of a new monopoly. ${ }^{278}$ Additionally, the increase in musical publications led to a greater diversity of printed music.

Although Stationers' copy rights and royal printing patents provided property-like exclusion rights, the law's conception of these rights was limited to the activity of literal copying. A broader conception of rights in an intangible work, which would supply the basis for claims against other kinds of uses of musical compositions, was not present. ${ }^{279}$ Consequently, modern claims of infringement made in relation to music sampling and other transformative uses would not have been cognizable under the privilege system. Indeed, describing the practices of self-styled "new Poets" in the high Elizabethan period, one historian writes: "It was a brief age of belligerent translation, adaptation, imitation, and plagiarism of anything and everything classical, French, and, especially Italian."280

\section{ii. Continental Europe}

275. See Patterson, supra note 16, at 90-91 ("Except for the printing patent, the works would be available to any printer or publisher."); SAUNDERS, supra note 262, at 48 (noting that the right to print law books and other useful reference texts was granted by royal patent).

276. The first Letters Patent given to music publishers in England was granted by Queen Elizabeth in 1575 to William Byrd and Thomas Tallis. REESE, supra note 226, at 784-85. They received a twenty-one-year monopoly on music printing. See Kerman, supra note 268, at 258 ("Tallis and Byrd were given the first privilege for the printing of 'pricksong' in 1575."). For the text of the Byrd-Tallis privilege, see Iain Fenlon \& John Milsom, "Ruled Paper Imprinted": Music Paper and Patents in Sixteenth Century England, 37 J. AM. MusicologicAL SOC’Y 139, 139-40 (1984).

277. After ten years, Tallis died and the privilege was assigned to another publisher, who further sublicensed his publishing rights. See REESE, supra note 226, at 787; KERMAN, supra note 268, at 258 ("Tallis died in 1585 and, after the expiration of the patent in 1596, it eventually passed to Thomas Morely in 1598. . . . by 1606 Morley's printer William Barley certainly had the patent.”).

278. KERMAN, supra note 268 , at 261 ("[T] he expiration of every patent is accompanied by a little flurry of music printing by unauthorized printers taking advantage of the few months before the grant and enforcement of a new monopoly.").

279. See, e.g., PATTERSON, supra note 16, at 43-44; Bracha, supra note 12, ch. II at 18-19.

280. KERMAN, supra note 268, at 8; see also id. at 27 ("A considerable number of English madrigal poems can be positively identified as translations from Italian madrigals."); CHANAN, supra note 211, at 125 ("Like all composers of the day, educated or not, [John] Dowland regularly based new pieces on popular melodies."). 
Although music publishers in other parts of Europe were members of a common guild or had guild-like arrangements, ${ }^{281}$ the centralization reflected in the Stationers' method of operations did not have a ready analog elsewhere in Europe. Instead, privileges tended to be granted for specific works or classes of works. For example, the privilege of printing all liturgical music came to rest in the hands of a single publisher in Rome. ${ }^{282}$ In the case of some early privileges, publishers printed the full text or a summary of the privilege in the front of a book to put the public on notice that the book was legally protected. ${ }^{283}$ But, the scope of the rights granted by a privilege was not uniform and could be quite limited. The legality of shared repertories was problematic because in some cases music books as a whole, not the individual works contained therein, were protected by privileges during the middle decades of the sixteenth century. ${ }^{284}$ In France, music publishers obtained the same exclusive privilege as book publishers in $1527 .{ }^{285}$ As with book publishing, a musicpublishing contract between publisher and composer gave all rights of reproduction to the publisher. ${ }^{286}$ Initially, composers often had to raise the funds to pay the publisher to publish their music.

Privileges often were granted in response to petitions claiming that a publisher would not be willing to risk the sizable investment in bringing a new volume to market absent legal protection. ${ }^{287}$ In modern parlance, we can say that political authorities accepted the argument that a public goods problem existed that needed a solution in the form of exclusive rights. But as modern economic theory also points out, creating exclusive rights raises a different problem because the rightsholder can and will restrict the flow of socially valuable information-including musical information. This dilemma sometimes is called the underdistribution problem.

Renaissance political authorities soon found that they had to strike a balance between the exclusive rights granted by a privilege and the public's

281. See, e.g., BERNSTEIN, supra note 229, at 12-14 (describing guild relations of Venetian publishers).

282. See Duggan, supra note 226, at 1.

283. ARMSTRONG, supra note 245 , at 5 .

284. WEAVER, supra note 232, at 290-91.

285. ATTALI, supra note 169 , at 52 . Books published as early as the 1470 s indicated that publication had been under royal privilege, although the first written record of a privilege granted in England appeared in 1518. See RANSOM, supra note 16, at 25.

286. ATTALI, supra note 169 , at 52-53.

287. Elizabeth Armstrong provides a detailed description of how one obtained a printing privilege in Renaissance France. See ARMSTRONG, supra note 245, at 63-77. The first step would be to draw up a requete or petition. The text of this petition would refer to the applicant in the third person, and request the favor he desired along with justifications. Initially, an applicant would require the services of a lawyer, but once through the process a few times, the applicant could rely on previous forms and do it himself. Id. at 63. Of the justifications offered for the grant, the most recurring motive was to ensure a fair return for an author's labors and expenses. Id. at 79-83. 
need for published information. For example, the limits of a privilege's scope had to be clarified so that follow-on publishers knew what material they were free to print. ${ }^{288}$ In Venice, publishers had become aggressive in seeking privileges and by 1517, "so many privileges had been granted, some of them for large groups or whole categories of books and for long periods, that it was paralysing the Venetian book-trade, and the Senate revoked all existing privileges not issued on its own authority."289 Finally, because the exclusive rights gave the publisher some power over price, the authorities would limit that power by either demanding as a condition of the privilege that the work be sold at a "reasonable" price or, in some cases, by dictating a maximum price for a work protected by a privilege. ${ }^{290}$ (This feature of government price control subsequently found its way into the first copyright act, the Statute of Anne of 1710, which permitted consumers to complain to high government officials that a bookseller's price for a specific work was "high and unreasonable" and permitted such officials, upon inquiry, to "Limit and Settle the Price of every such Printed Book and Books . . . as to them shall seem Just and Reasonable."291)

\section{iii. Legal Enforcement of Privileges}

Methods of enforcing the rights granted by privileges also were subject to some local variation. Enforcement depended on the jurisdiction of the privilege-granting authority. ${ }^{292}$ The geographic scope of many privileges was quite limited because countries such as Germany, Italy, and the Netherlands were not the unified nation-states we know today. The practice of republication generally was legal because privileges did not extend further than the borders of the authority that had granted the

288. During the sixteenth century, some music publishers began to misrepresent the scope of the privilege protecting the publication. See HeARTZ, supra note 228, at 77. To counter the practice, a 1561 law was enacted in France requiring that the publisher print the entire privilege. See $i d$. The practice of overstating the scope of legal protection continues today, most notably in the form of the "FBI" warning that movie studios attach to the front of motion pictures on DVD or VHS. The warning states that any unauthorized reproduction or use is prohibited by law, ignoring the privilege of fair use.

289. ARMSTRONG, supra note 245 , at 6-7; accord BUGBEE, supra note 48 , at 45 ("[A]buses arose as publishers flocked to the government to reserve well-known titles for themselves.").

290. See ARMSTRONG, supra note 245, at 73-75 (providing examples, mostly French, of price controls attached to privileges).

291. 8 Anne c. 19 (1709), available at http://www.copyrighthistory.com/anne.html (last visited Feb. 14, 2004).

292. E.g., ARMSTRONG, supra note 245 , at 11 ("Privileges were naturally valid only within the jurisdiction of the authority which granted them.”). Apparently some disputes arose over how to define the privilegegranting authority's jurisdiction. For example, in 1513 Pope Leo X granted Petrucci a privilege good against all Christians, under pain of excommunication. See HeArTZ, supra note 228, at 153. This claim of privilege apparently was ignored outside Italy, and some in France claimed specifically that papal privileges granted to Italian printers were inapplicable in France. See id. 
privilege. ${ }^{293}$ Careful modern historians nonetheless at times mischaracterize the practice of republication as "piracy," 294 while others warn of the dangers of anachronism when treating legal but unauthorized publication as wrongful. ${ }^{295}$ The law did not leave publishers without recourse-for works that were likely to have appeal in many jurisdictions, some publishers would seek simultaneous privileges from relevant authorities. ${ }^{296}$

Two kinds of enforcement issues would arise: unauthorized publication within the jurisdiction of the privilege-granting authority or publication within the authority's jurisdiction authorized by a conflicting or overlapping privilege. In England, privileges or letters patents could be enforced by the courts, but records reflect that few cases were brought during the sixteenth and early seventeenth centuries. Instead, where publication took place within the privilege-granting authority's jurisdiction, it appears that publishers would appeal directly to their political patrons for assistance. ${ }^{297}$

Similarly, the Venice music publishers could seek redress in court for infringement of their privileges, but they opted for more informal and expedient dispute resolution. ${ }^{298}$ The Venetian printers were among the first with formal arbitration proceedings. ${ }^{299}$ As with some modern arbitration arrangements, "the opposing parties selected another bookman to serve as an adjudicator; the two chosen then named a third, and the

293. In the words of Rasch:

No one could keep a Dutch publisher from reprinting works originally issued in Italy, France or England; no one could keep an English publisher from reprinting a Dutch edition of whatever. In addition, privileges were seldom if ever granted for publications that were in themselves not an original edition but a reprint of work already published before.

Rudolf Rasch, Estienne Roger and John W alsh: Patterns of Competition Between Early-18th-century Dutch and English Music Publishing, in The NorTh SeA AND Culture (1550-1800), at 401 (Juliette Roding \& Lex Heerma van Voss eds., 1996); see also HEARTZ, supra note 228, at 153 ("Printers in Germany, of course, had nothing to fear from the strictures of the Venetian Senate's privilege.”).

294. See, e.g., FENLON, supra note 215, at 53 (describing how Attaingnant's repertory was "pirated" by publishers in Lyon and Frankfurt); HEARTZ, supra note 228, at 121 (describing apparently legal republication as "piracy"); ARMSTRONG, supra note 245, at 11 (same).

295. Cf. Sarah Adams, International Dissemination of Printed Music During the Second Half of the Eighteenth Century, in Dissemination of Music, supra note 226, at 21, 35 (reacting to use of "piracy" as anachronistic mischaracterization even of later practices and noting that "[i]n most cases reprinting a musical work without the composer's sanction simply was not an illegal activity until very late in the eighteenth century").

296. See WEAVER, supra note 232, at 289.

297. KRUMMEL, supra note 252, at 10 ("There were no precautions and seldom any official concern ... for avoiding an overlap between two or more royal grants; and the burden of enforcement usually rested mostly on the grantee, who called on his patrons and friends for support."); see also WEAVER, supra note 232, at 252 ("The problem with a privilege was that it could be enforced only in the geographic region over which the issuing authority had jurisdiction."). This was a "problem" from the publisher's perspective. From the consuming public's perspective, the limits of legal control yielded the benefit of cheaper sheet music.

298. See BERNSTEIN, supra note 258, at 17.

299. See id. 
three had the responsibility of reaching a binding decision." 300

\section{b. The Economics of Music Publishing}

Insofar as the law grants rights against literal copying, its primary economic function is price control. In order to encourage investments in expressive endeavors, printing patents or copy rights granted, and modern copyright grants, the owner the ability to limit direct competition so as to create sufficient power over price that the owner can recoup the investment in producing the work. ${ }^{301}$ Despite the limited geographic scope of a privilege, such measures did have the effect of limiting competition for some works. ${ }^{302}$

Because proprietary rights in printed music were only one factor influencing the development of the industry, some understanding of the fledgling music business's economics is helpful for putting the law in context. Unlike copyright, the privilege was not justified by a need to create a return to cover the composer's costs of composition. Those costs were covered by patrons or by the composer. Also weakening the economic case for protection was the fact that the costs of running a competing press were essentially the same as the initial publisher's, meaning that the copyist would have little incentive to directly compete. The primary explanation for the publisher's privilege, other than favoritism or corruption, was that competitors could cherry-pick by publishing only titles or composers with proven success in the market. This risk had substantial economic weight because the direct costs of publishing were quite sizable. Faced with unregulated competition, a publisher would have had only its lead-time advantage as an incentive to bring unproven talent to market. Because it often took years to sell a print run numbering in the hundreds, the lead-time advantage would have supplied an insufficient incentive for music publishers. Consequently, over time, the publishers' privilege played a valuable role in stimulating the printing and distribution of musical expression.

Initially, however, even with the legal protection offered by the privilege system, publishing music was a more challenging venture than book

300. Id.

301. Two underlying assumptions are that (1) there is sufficient demand for a work, or class of works, that the prospect of direct competition is the key variable in an innovator's decision to invest in creating the work, and (2) the costs of initial production are sufficiently high and the costs of competition sufficiently low that others will have economic incentives to directly compete for distribution of the expressive work.

302. See, e.g., ARMSTRONG, supra note 245 , at 11 (explaining that in printing centers, protection from local competition was economically meaningful and that because privilege also granted right to prohibit importation, it protected local market against distant competitors). 
publishing. ${ }^{303}$ Printing costs were higher and the audience was smaller. From the publishers' perspective, these aspects of music publishing had the benefit of reducing enforcement costs because competition was less likely. ${ }^{304}$ There were offsetting difficulties — not only was demand limited by musical illiteracy, supply also was a problem. ${ }^{305}$

Thus, even with legal protection from direct competition, publishers bore significant market risk. According to one historian, privileges "may be viewed as seeking to serve music publishing by providing protection, encouragement, and profit. Unfortunately, there were no profits to be made from music publishing, and hence the protection was unnecessary, and the encouragement doomed to failure." ${ }^{306}$ Some evidence supports this gloomy perspective. ${ }^{307}$ In England, the only line of Byrd and Tallis's business that was profitable was blank music paper for use by the hand copyists. $^{308}$ And, as has been true with many businesses built to exploit new communication technologies, the failure rate was high among early entrants. ${ }^{309}$ However, after single-impression printing spread through-out Europe in the 1530s, and demand for printed music increased, the economics of running a publishing business were such that at least a few large firms were able to operate profitably. ${ }^{310}$

\section{i. Production Costs}

To produce printed music, one first needed the music. In theory, publishers could choose between publishing an existing repertory or new compositions, but printers did not have ready access to an extensive written repertory other than liturgical music. ${ }^{311}$ Following the spread of

303. From an economic perspective, what distinguishes a music publisher from a music printer is that the publisher uses its capital to acquire and print a musical work in the hope of earning a profit and bears the risk of a financial loss when demand is insufficient. A music printer would be one who receives income from use of the press but bears no market risk with regard to the success of the printed music. As is described infra, early music publishers acted in both capacities, and some also integrated the functions of music distributors into their operations as well.

304. E.g., CHANAN, supra note 211, at 115-17.

305. See id. at 114 .

306. KRUMMEL, supra note 252, at 32-33; see also BERNSTEIN, supra note 258, at 109 ("In comparison with other fields, the music book trade did not generate an impressive income.").

307. For example, in England, Byrd and Tallis found that even with their patent, music publishing was unprofitable. See Fenlon \& Milsom, supra note 276, at 140 ("the Byrd-Tallis patent seems not to have been a commercial success").

308. KRUMMEL, supra note 252, at 15.

309. Id. at 33 (" $[T]$ he patents supported music publishing by encouraging the patentees in the false hopes that there were profits to be made, tastes to be served, and protection to be secured."); see also FENLON, supra note 215 , at 36 (“ $[T]$ here was a good deal of risk involved in entering the music market.").

310. See infra notes $344-57$ and accompanying text.

311. See, e.g., Giulio M. Ongaro, Venetian Printed Anthologies of Music in the 1560s and the Role of the Editor, in 
single-impression printing, publishers' demand for new compositions increased. ${ }^{312}$ Acquiring the musical works apparently did not entail significant costs for publishers. Composers generally did not look to earnings from publication as a significant source of revenue. Instead, professional composers relied on patronage for their earnings. Music publishers also printed music by amateur composers who, in essence, selffinanced the composition process. ${ }^{313}$ During the sixteenth century, if publishers paid the composer at all, payment usually would be a quantity of books rather than cash—although some evidence indicates composers occasionally were paid a one-time fee. ${ }^{314}$ Because new compositions were in short supply, publishers did invest some resources in procuring musical manuscripts. ${ }^{315}$ When in need of short or more rudimentary compositions to fill an anthology, publishers may have relied on in-house talent to supply new works anonymously. ${ }^{316}$

In other cases, composers with access to resources would finance the publication and simply pay the printer a fee. ${ }^{317} \mathrm{~A}$ variation on this arrangement involved the composer shopping for a patron to finance publication in return for the dedication. ${ }^{318}$ One historian argues that dedications, a throwback to a pre-print, gift economy, reemerge in secular anthologies only after the commodification of printed music was firmly

DisseminATION OF MUSIC, supra note 226, at 43, 44 (footnote omitted) (noting that early poetry anthologies were retrospective because "the established canon was that of the fourteenth century, a situation without parallel in music at the beginning of music printing, ... [where] the focus [was] on more recent material, not more than a generation old").

312. Generally, early printers published anthologies, and the nature of the anthology changed during the course of sixteenth century. There were four types: (1) the miscellaneous anthology, determined apparently by availability of material; (2) the nominal anthology, which was usually predominantly a single-composer collection with a few additional compositions added; (3) thematic anthologies of previously unpublished work, reflecting a metamessage from the compiler/publisher; and (4) retrospective anthology, often a "best of" collection of proven, popular pieces. See id. at 43-46 (describing taxonomy of sixteenth-century musical anthologies).

313. See FENLON, supra note 215, at 85 (Scotto and Gardano began publishing music by provincial musicians beginning around 1540).

314. See BERNSTEIN, supra note 229, at 99-101 (discussing what is known about publisher-composer arrangements, including one composer's unsuccessful attempt to find a buyer for his score); HEARTZ, supra note 228, at 93 ("The typical payment throughout the sixteenth century, if payment there was, consisted of a certain number (usually small) of printed copies."). Students of contract law may be interested in this fact as an illustration of the importance of context when defining the expectation interest in a suit for breach of contract. See, e.g., Freund v. Wash. Square Press, Inc., 314 N.E.2d 419, 421-22 (N.Y. 1974) (holding that author's expectation interest in publication agreement was share of royalties rather than receipt of a quantity of books and therefore damages would be limited to provable lost royalties rather than cost of publishing books).

315. See FENLON, supra note 215, at 75-77 (describing how once market had developed for contemporary compositions, publishers invested in relationships with composers to procure their latest work).

316. See Martha Feldman, Authors and Anonyms: Recovering the Anonymous Subject in Cinquecento Vernacular Objects, in Cultures OF PRINT, supra note 234, 163, 169 (describing evidence for theory of in-house composition).

317. See, e.g., HEARTZ, supra note 228, at 95 (describing one such arrangement).

318. See Bernstein, supra note 229, at 106 (describing this practice). 
established. $^{319}$ Although styled as a "gift," the dedication effectively conferred a form of authorship on the patron in exchange for protection, loyalty, and material support. ${ }^{320}$ Composers received a share of profits only if they contributed capital as well as the musical work to the publishing venture. ${ }^{321}$

The other inputs into printed music were raw material (paper), capital equipment (the press and type), ${ }^{322}$ and labor to print and edit the final text. ${ }^{323}$ In today's economy, we generally assume (correctly) that the raw material for commodified intellectual works is a relatively small component of the publisher's cost. Whether such material is paper, film, or blank media (tapes, CDs, DVDs, etc.), competitive markets have driven down the price of these commodities, leaving the costs of producing the intangible object and marketing the finished product as the principal costs. The situation was quite different for early music publishers. Paper alone represented up to seventy-five percent of the direct costs of production. ${ }^{324}$ To reduce transport costs, music books often were shipped unbound, with binding costs to be borne by the consumer. ${ }^{325}$ Wages and capital costs also were quite significant. ${ }^{326}$ The cash-flow challenges posed by these significant costs gave publishers little room for error when making publication decisions and made the threat of direct competition a real concern.

\section{ii. Markets for Printed Music}

By and large, music publishers relied on market exchange to finance their operations, ${ }^{327}$ although aristocratic or institutional patrons financed select publications and may have provided more general investment. ${ }^{328}$

319. See Feldman, supra note 316, at 176 (citing 1555 as year when anthologies become regular object of dedication).

320. Id. at 176-77.

321. See Bernstein, supra note 229, at 101 (describing composers who profited from their roles as investors and booksellers of their own work).

322. According to Heartz, "[t]he investment represented by a press was surprisingly small." See HEARTZ, supra note 228, at 118 (describing press prices). For a description of the labor and materials needed to cut, strike, and cast type, see $i d$. at 46. By contrast, Bernstein asserts that " $[t]$ he initial cost of running a print shop required an enormous outlay of capital or printing presses and typographical equipment." BERNSTEIN, supra note 229, at 30 .

323. For details on the labor required, see HEARTZ, supra note 228, at 117 (describing roles of the puller, inker, compositor, proofreader, and master printer). See also BERNSTEIN, supra note 229, at 30-31 (describing workforce). For a detailed description of a sixteenth-century print shop's operations, see id. at 29-72.

324. See FENLON, supra note 215, at 29.

325. See id. at 11 (describing transport arrangements).

326. See, e.g., BERNSTEIN, supra note 229, at 30-31 (describing labor costs).

327. See, e.g., id. at 16 (“[M]arket demand determined what they should print.”).

328. See, e.g., FENLON, supra note 215, at 50-51 (describing patronage of Attaingnant); BERNSTEIN, supra 
The markets for printed music varied and grew with increased music literacy and the increased disposable income enjoyed by the emergent middle class composed of skilled artisans and professionals. ${ }^{329}$ These markets were international. Through trade fairs and catalogs, publishers in the principal printing centers sent their books along established trade routes. ${ }^{330}$

Initially the surest customer was the Church, which had an identified need for liturgical music. ${ }^{331}$ The Counter-Reformation also stimulated demand for new liturgical works. ${ }^{332}$

The market for secular music had different segments. ${ }^{333}$ An important segment was the gifted amateurs, either at court or among the emergent bourgeoisie, who bought printed music to extend their performance repertory. ${ }^{334}$ This trend toward amateur literacy and performance was

note 229, at 74 (stating that dedication pages of Venetian music publications support inference that patrons supplied some capital, particularly during publishers' early careers); see also id. at 74-77 (describing joint-venture agreements among printers to finance publication).

329. See, e.g., Fenlon, supra note 210, at 35-36 (indicating difficulty in estimating size of sixteenth-century bourgeoisie-in some cities tax records indicate between 6 and 20 percent, depending on one's criteria—and that growth of musical literacy and practice most pronounced among this stratum of society); Fenlon \& Milsom, supra note 276, at 156-57 (during the Elizabethan era "there was a significant growth in musical literacy and patronage").

330. See, e.g., HEARTZ, supra note 228 , at 123-25 (describing international market for printed music); BERNSTEIN, supra note 229, at 85-94 (describing international trade pursued by Scotto and Gardano).

331. See FENLON, supra note 215, at 13-14 (stating that printers had good information about market for liturgical music and could adjust print runs and prices to meet demand); CHANAN, supra note 211, at 113; BERNSTEIN, supra note 229, at 20 ("Most of the music incunabula were Roman missals intended for liturgical use."); see also generally Duggan, supra note 226, (describing music in the Roman missal).

As the Reformation gained momentum, a market for Protestant liturgical music also developed. See, e.g., GROUT \& PALISCA, supra note 46, at 225-30 (describing development of Lutheran and other Protestant liturgical music); BROWN \& STEIN, supra note 207, at 274-78 (describing stance toward music of Luther, Calvin, and the nascent Church of England). Indeed, Martin Luther played the lute and took a keen interest in music's role in new liturgical ceremonies, even composing some melodies and vernacular verse for congregational singing. See BROWN \& STEIN, supra note 207, at 273-74; Fenlon, supra note 210, at 52 (commenting on Luther's skills as vocalist and instrumentalist).

332. In the closing years of the Council of Trent (1545-63), the Church endorsed the use of polyphony with the caveat that the music preserve intelligibility of the sacred texts and not borrow from secular compositions. See Brown \& STEIN, supra note 207, at 278-79; Fenlon, supra note 210, at 54-55. Rome's musical point person, Palestrina (neé Giovanni Pierluigi) produced numerous new works in accord with the Council's guidelines, although other composers continued to base Masses on madrigals and chansons. See id. at 279, 28386 (describing Palestrina's role and composers' responses to Council's directive).

333. The markets for secular and sacred music were not sharply divided. With some exceptions, publishers generally printed collections of music by different composers, and some of these collections included both secular and sacred music. See Haar, supra note 234, at 130-31 (describing publications that mixed sacred and secular music).

334. See FENLON, supra note 215, at 72-73 (describing market for secular music); id. at 79 ("[M]adrigals and motets had been sung in small circles of educated amateurs who sometimes organised themselves into more formally-constituted academies."); $i d$. at 42-43 (describing academies and noting that by mid-sixteenth century there were more than 200 academies in Italy). The voice was their principal instrument, although demand existed for keyboard and lute music as well. See, e.g., Grout \& PALISCA, supra note 46, at 205-08 (describing rise 
encouraged by Baldassare Castiglione's Il cortegiano (The Courtier), a widely disseminated book of manners for courtiers directing that the wellmannered courtier be able to sight-sing and be ready to provide vocal improvisations to simple instrumental accompaniment. ${ }^{335}$

Another market segment was musicians who provided dance music. Social dance played an important role in social relations during the Renaissance, and courtiers also were expected to be accomplished dancers. ${ }^{336}$ Although dance music still frequently was improvised, ${ }^{337}$ as it had been during the Middle Ages, the authority of the score began to assert its influence. ${ }^{338}$ By the end of the sixteenth century, publishers increasingly produced collections of dance music for lute, keyboard, and ensembles. ${ }^{339}$ Finally, a small but important group of buyers were the collectors and archivists, some of whom treated printed music more as literature than as a tool to enable performance. ${ }^{340}$

of instrumental music). Indeed, we see the development of the middle class amateur instrumentalist in the sixteenth century. See BROWN \& STEIN, supra note 207, at 250-52 (describing growth in market for instrumental music).

335. See FENLON, supra note 215, at 73 (describing Il cortegiano (1527) and its recommendations). One example supporting the view that the book's recommendations were widely followed is a 1597 book published in London entitled A Plain and Easy Introduction to Practical Music, which relates a fictional dialogue in which a character is deeply embarrassed to recount having been unable to sing a part given to him after a dinner party. See Lowinsky, supra note 130, at 520 (quoting book at length). From Italy, a novella by Gentile Sermini recounts a tale in which a young man courts a young woman by spontaneously inviting a well-known man-about-town passing under the young woman's window to join him in a song (a ballata). The stranger obliges, demonstrating that young gentlemen were expected to share a repertory of polyphonic songs and be able to perform their respective parts without preparation. See FrAnK A. D'ACCONE, The Civic Muse: Music AND Musicians in SieNA DURING THE MidDle AgES AND tHe RENAissance 637 (1997) (recounting tale).

Il cortegiano also encouraged women to study and play music as a leisure activity because their "tender and delicate spirits are readily penetrated with harmony and filled with sweetness." BROWN \& STEIN, supra note 207, at 87 (translating and quoting $I /$ cortegiano). The book further identified which types of music and instruments were inappropriate for feminine musical expression, and these notions were validated and reflected in the choices made by powerful patrons such as Isabella d'Este, Lucrecia Borgia, and Elisabetta Gonzaga. See id. at $87-89$.

336. See, e.g., Grout \& PALISCA, supra note 46, at 214; D’ACCONE, supra note 335, at 641-46 (describing importance of dance and dance music in Siena).

337. See, e.g., BROWN \& STEIN, supra note 207, at 250 (describing how professional "instrumentalists performed almost exclusively without written music in the fifteenth century").

338. See, e.g., GROUT \& PALISCA, supra note 46, at 214.

339. See, e.g., id.; BROWN \& STEIN, supra note 207, at 269-70 (describing growth of published dance music and treatises on dance technique).

340. See FENLON, supra note 215, at 10-12 (describing importance of collectors to historians); HEARTZ, supra note 228, at 126-36 (tracing Attaingnant publications to Renaissance collections amassed throughout Europe); BERNSTEIN, supra note 229, at 93-94 (describing aristocratic and institutional collectors). Among the many parallels between the emergence of paper publishing during the Renaissance and digital publishing on the Internet in the 1990s is the key role that visionary archivists have played in making materials from the early period available to later generations. Researchers and others interested in the development of the Internet owe a very large debt of gratitude to Brewster Kahle and the staff of the Internet Archive, http://www.archive.org, for preserving materials that otherwise would have been swept away by the shifting sands of the World Wide Web. 


\section{iii. Competition}

With little control over costs, early music publishers risked significant financial loss if demand for their music was insufficient. ${ }^{341}$ When demand was sufficient, publishers faced the risk of potential competition. In some cases, the privilege system offered anemic protection. ${ }^{342}$ Even with the protections of the privilege system, the publishers' printed music had to survive monopolistic competition with the offerings of other publishers unless a music publisher had a full monopoly on music printing. ${ }^{33}$

During the sixteenth century, as the market for printed music grew, the trade became more profitable-market leaders and those publishers who received supplemental income from patronage appeared to have done well. ${ }^{344}$ In Italy, for example, second-generation Venetian publishers Scotto $^{345}$ and Gardano ${ }^{346}$ appeared to enjoy some financial success. Gardano specialized in madrigals and adopted a successful strategy of publishing short print runs of the latest compositions by contemporary composers interspersed with reprints of successful editions. ${ }^{347}$ The Scotto

341. See, e.g., HEARTZ, supra note 228, at 121 (describing how publisher would be wary of printing more books than could be sold quickly because the publisher "could not afford to see his capital, represented by the expensive commodity of paper, tied up on the shelves.”).

342. See id. (noting how unauthorized reproduction was common in the Paris market until 1530, when royal privileges became more effective).

343. In the first generation, Petrucci's apparent success in the early sixteenth century encouraged others to enter the music publishing trade. Andrea Antico was the only competitor who posed a real threat. See FENLON, supra note 215, at 23-24 (describing Petrucci-Antico rivalry). Antico obtained a papal privilege that gave him some security, and his position improved further when Pope Leo X withdrew the privilege to print organ tablature from Petrucci, who had chosen not to exploit the exclusive right, and assigned it to Antico, who produced a collection of instrumental music three months later. See id. at 24. Fenlon explains Petrucci's increasing fiscal conservatism as reflecting a judgment that the market for printed music was too small and uncertain to justify new capital investment (such as for new fonts to print organ music). See id. at 24-25; $f$. HEARTZ, supra note 228, at 107-09 (explaining Petrucci's financial woes as stemming from overpriced books, dependence on outside capital, and lack of access to export market due to war and related trade disruptions).

344. Consider, for example, the symbiotic arrangement of the Antwerp team of Waelrant and Laet. Laet was the established printer and contributed his knowledge of the technology and the trade. As a composer, Waelrant contributed his proof-reading skills and received in return notoriety because he was able to insert one or more of his compositions in almost every compilation the pair published. See WEAVER, supra note 232, at $117-18$.

345. See generally BERNSTEIN, supra note 258 (describing in detail the history of the Scotto Press); see also FENLON, supra note 215, at 33 (explaining how one family member, Ottaviano Scotto, entered the music publishing trade through a joint venture with Antico).

346. Antonio Gardano, a Frenchman (neé Gardane), received a Venetian privilege to print music in 1538. Taking a significant financial risk, Gardano apparently invested directly in the costly capital equipment necessary to engage in single-impression printing and then used the quicker production process to bring to market new secular offerings rather than recycled stand-bys. See FENLON, supra note 215, at 63-70 (describing Gardano's business arrangements).

347. See id. at 69 (describing Gardano's strategy and declaring that "[f]or the first time in Italian music printing the activity was not only secure but was strategically connected to the music that composers were currently writing"). 
house also adopted certain strategies to minimize risk and maximize profitability. One method involved printing commissioned works. ${ }^{348}$ Many Venetian composers paid for the privilege of having their works printed, and in doing so became partners in the printing venture. These early commissioned works signaled to composers that the middle classes were a supplement for, or even an alternative to, the aristocracy as a source of financial support. Further, Venetian publishers sought out international markets to take advantage of economies of scale. ${ }^{349}$ Scotto and Gardano embraced vertical integration, employing not only printers but also procuratori, whose job was to transport and sell books in Italy, Spain, and Northern Europe, ${ }^{350}$ because the "[r] eal money in music publishing lay not with the printing of books, but with their distribution." 351 Finally, Girolamo Scotto chose to collude rather than compete with his principal competitor, Gardano, to divide the Italian market. ${ }^{352}$ These strategies were successful enough to keep the Scotto press in business: Scotto received investment income comparable to members of the emerging professional class of lawyers and doctors. ${ }^{353}$

In France, Attaingnant, who displayed keen business acumen, succeeded in running a profitable operation also; he had broader protection from competition through privileges than did his Italian counterparts and he received greater direct investment from the government. ${ }^{354}$ Collusion

348. From surviving contracts, dedications, and privileges, we can surmise that many Venetian editions were paid for by others. See BERNSTEIN, supra note 258, at 115. In these cases, the printer received a fixed fee and bore no market risk. Id.; see also FENLON, supra note 215, at 54-55 (describing arrangement by smaller Italian printer, Dorico, by which he was guaranteed a profit).

349. See BERNSTEIN, supra note 258, at 123 . Even with press runs of only 500 or 1,000, the population of Venice (population 170,000 circa 1540) was too small to absorb the whole run, and Scotto needed to sell outside the range of his privileges. Id.

350. See Bernstein, supra note 229 , at 85 .

351. Id.

352. See FENLON, supra note 215, at 70-72 (rejecting depiction of cut-throat competition promoted by earlier musicologists and presenting evidence of collusion); HEARTZ, supra note 228, at 159 (acknowledging scholarship alleging competition but suggesting that evidence of shared types "raises the possibility that the relationship was one of collusion more than competition").

353. BERNSTEIN, supra note 258, at 46.

354. See FENLON, supra note 215, at 50-52 (describing how Attaingnant could afford to print work of contemporary French composers through investment of patron, who wanted to promote the reputation of France as a center of cultural production); see also HEARTZ, supra note 228, at 164 ("As long as King Francis reigned, privileges for music were granted only to Attaingnant.”). But of. HEARTZ, supra note 228, at 100 (acknowledging the absence of "foreign" composers in Attaingnant's publications but speculating that "[i]n all likelihood, composers remote from Paris or outside the realm did not actually send their pieces to Attaingnant"). Governments have at other times subsidized music dissemination for political purposes. Consider the recent launch of Radio Sawa through which the United States government broadcasts American pop music to the Middle East in the hopes of enticing listeners also to listen to interspersed news and information as part of war on terrorism. See, e.g., Susan Taylor Martin, U.S. Aims Pop Music At Arab World, St. Petersburg TimeS, Oct. 17, 2002. For the Government's press release, see http://usinfo.state.gov/regional/nea/text/0322sawa.htm. 
through "gentleman's agreements" also was relied on to limit competition: the two cardinal rules for Parisian publishers stated in an anonymous manuscript were (1) keep projects secret until publication, and (2) keep authors, correspondents, and workmen in as dependent a position as possible. ${ }^{355}$ Attaingnant repaid his patron by effectively giving birth to a new genre- the Paris chanson. Most of the nearly two thousand chansons published were designed for the taste of Francis I's court. ${ }^{356}$ Succeeding Attaingnant was the financially successful partnership between Robert Ballard and his half-brother Adrian Le Roy. ${ }^{357}$

By the end of the sixteenth century, the market for commodified music had begun to shift and grow, as the cash economy, music literacy, and ownership of musical instruments increased among the burgeoning middle class. $^{358}$

\section{Composers' Claims}

Composers' claims of a proprietary relation to their music also took shape in the pre-copyright era. The wider dissemination of printed music combined with increasing music literacy rendered music increasingly visual as well as auditory, and musicians who composed music began to better understand that their compositions could be, and would be, preserved beyond their lifetimes. ${ }^{359}$ We have seen how the development of musical notation gave the printed score a new kind of authority as it became standardized and capable of conveying with some precision the composer's vision of the work to be performed. ${ }^{360}$

355. See HEARTZ, supra note 228 , at 121 .

356. See BROWN \& STEIN, supra note 207, at 191 (describing development of Parisian chanson); Freedman, supra note 228, at 191-92. Thematically, at least, the roots of the modern pop song can be found in this style. Composers departed from many of the formal conventions governing late medieval secular music, such as those regulating lyrical meter and content- the song of unrequited love. Composers now used poetry without a fixed rhyme scheme, and the songs address a wider range of topics, including humorous and bawdy themes. See BROWN \& STEIN, supra note 207, at 191-95; Freedman, supra note 228, at 191-92 (describing range of topics addressed in chansons).

357. LeRoy and Ballard became partners in 1551 and almost immediately "were granted both the permanent privilege to publish any vocal or instrumental music for which earlier privileges had expired, and the privilege to be the exclusive publisher of the king's music." ATTALI, supra note 169, at 53; HEARTZ, supra note 228 , at 165 . Unlike book publishers, who could rely on substantial back-lists of existing works to produce income in the early years of publishing, music publishers did not have many scores to rely on, as the system of notation had only recently stabilized. ATTALI, supra note 169, at 53. Music publishers such as Le Roy and Ballard thus relied on the output of contemporary composers, who were entirely dependent on these publishers for publishing revenue.

358. See CHANAN, supra note 211, at 123-24 (describing growth of middle class music consumption).

359. See id. at 73; BERNSTEIN, supra note 229, at 99 ("Composers quickly became aware of the possibility of addressing a larger audience through the press.").

360. See CHANAN, supra note 211, at 69-72 (describing increased authority of the score). Notation became 
As musical texts became more readily available and more authoritative, composers began to make claims that their names be associated with the text and the music reflected in the text. ${ }^{361}$ Composers increasingly became self-aware subjects. In part, this development was due to the general turn toward humanism among intellectuals. ${ }^{362}$ Self-awareness also grew from the use of notation to conceive of, and visualize, the whole of a complex composition flowing from the composer's mind. ${ }^{363}$ Finally, composers' subjectivity grew in response to the alienation of their work, as printed scores were sold in markets on terms and conditions over which they had very little control. ${ }^{364}$ Many Renaissance composers, in their dedications to their respective patrons, refer to their compositions as their "children" being sent alone into the world and implore the patron to protect the work. ${ }^{365}$ Although publishing offered composers the ability to increase knowledge of their work through broad dissemination, as an economic matter it would not be until the nineteenth century that composers could rely on copyright to extract from publishers sufficient revenues to make a living. ${ }^{366}$

Music historians treat the late medieval composer Guillaume Dufay as a transitional figure both in terms of his musical innovations and in terms

increasingly standard across Europe, and that system permitted music to be performed by the musically literate with no prior familiarity with a piece of music. The system identified absolute and relative pitch as well as time value for each note. "To some extent the availability of printed music created both the idea of a repertory and its actual existence." RAYNOR, supra note 130, at 99.

361. As is discussed above, some fourteenth-century composers had begun to sign their compositions and dedicate compositions to well-regarded composers upon their deaths, see supra note 196, but it was not until the Renaissance that the practice became common. See Lowinsky, supra note 130, at 525 (many Renaissance manuscripts "are still ascribed to the fertile composer known as incertus autor [, b]ut the identity of the overwhelming majority of compositions is well established.").

362. A full discussion of the numerous changes in compositional technique and conception is beyond the scope of this Article. A few essential points are first that Renaissance composers consciously discarded prior melodies, rhythms and forms so as to be "free from all shackles." See Lowinsky, supra note 130, at 529. One example was a broader understanding of which musical intervals were acceptable (consonances) rather than undesirable (dissonances). Two intervals, the third and the sixth, which are essential harmonies used in nearly all modern Western popular music were deemed dissonant according to the Pythagorean theory that predominated during the Middle Ages. See id. at 530. Second, composers consciously sought to recreate or recover ancient Greek music and particularly sought to follow Plato's admonition that music should reflect the meaning of the lyric. See id. at 522, 552. Finally, the composer came to "conceive of his work as a well planned and carefully organized whole rather than a structure of several successively erected layers." Id. at 529.

363. See, e.g., id. at 533 ("The invention of the musical score, a form of notating the different parts of a composition in vertical order so as to make their simultaneous character and interplay visible," originated in 1480.); see also id. at 542 ("The two principal ideas from which music has since the sixteenth century drawn its inspiration, music as expression, as painting in tones, and music as structure based on thematic work, both originated in the Renaissance.").

364. See Feldman, supra note 316, at 164.

365. See, e.g., van Orden, supra note 142 , at xvii.

366. See, e.g., WEAVER, supra note 232, at 117 ("[Renaissance] composers generally offered their music free of cost to the publisher [because] ... the prospect of achieving fame through publication would have overridden the desire for financial gain."). 
of his social role as composer. ${ }^{367}$ Dufay was the dominant composer in what now is France between 1425 and 1450, and he remained active well through the 1460s. ${ }^{368}$ Dufay composed primarily for distinct occasions, still writing monophonic chant for many liturgical occasions but also introducing polyphonic works for both religious and secular occasions. ${ }^{369}$ It would be unusual to find a religious composer making proprietary claims to his or her compositions because such composition was viewed as merely supplementing an existing body of work controlled by the Church. ${ }^{370}$ Indeed, unlike other artists, who had begun to receive compensation in exchange for each work produced, ${ }^{371}$ composers still officially were musical laborers employed on a salaried basis. ${ }^{372}$ But we do begin to see Church scribes and compilers identifying Dufay as composer of some of his religious music. ${ }^{373}$

By the late fifteenth century and through the sixteenth, cultural practices throughout Europe reinforced composers' emerging self-identity as artists rather than artisans. Written accolades in manuscripts and printed treatises began to appear, praising Dufay and some of his contemporaries. ${ }^{374}$ The humanistic art of demonstrating one's own learning and verbal dexterity by lauding another required an object of affection, and in the sixteenth

367. See David Fallows, Dufay 1 (rev. ed. 1987) ("With astonishing unanimity modern critics have found Dufay by far the most interesting and fulfilling medieval composer."); BROWN \& STEIN, supra note 207, at 25 ("It is no exaggeration to say that Guillaume Dufay (ca. 1400-1474) was without doubt the greatest of the early fifteenth-century composers and one of the great figures in the history of western European music.").

368. See REESE, supra note 226, at 34. He began his career as a choirboy, probably around 1409 in Cambrai, and his first known composition dates from 1420. Id. at 48. Most of his positions were within the Church, including membership in the Papal Choir between 1428 and 1433 and then again from 1435 to 1437. See REESE, supra note 226, at 49; BROWN \& STEIN, supra note 207, at 26; see also FALLOWS, supra note 367, at 3 ("Dufay, like practically all composers of his time, was employed for most of his life as a church musician and more specifically as a singer.").

369. See FALLOWS, supra note 367, at 4 (Dufay's music reflects preference for polyphony in wealthiest religious institutions).

370. See id. at 3 ("[T] o compose chant was to add something to the sacred liturgy of the church; it was not an occasion for individual show or for willful originality.").

371. See, e.g., Lincoln, supra note 216, at 1093 (describing custom among visual artists to charge for painting based on the number of human figures); see also id. (describing 1457 lawsuit in which patron sued the artist Andrea Mantegna because she had paid for a painting with twelve apostles and-because of space limitations—-had received a painting with only eight).

372. See FALLOws, supra note 367, at 5. The closest Dufay came to being distinctly compensated for his compositional contributions is an advance on his salary he received in 1452 , a time when he was very wellestablished. See id. Dufay's successor in terms of compositional fame, Josquin des Prez appears to have been paid by Burgundian ruler Charles V for chansons presented in 1520. See Picker, supra note 219, at 231.

373. For example, a number of works are ascribed to Dufay in the Trent codices—seven mid-fifteenth century manuscripts comprising roughly 1,900 musical works-as well as to other composers, but a significant proportion remain anonymous. See BROWN \& STEIN, supra note 207, at 55; FALLOWS, supra note 367, at 57 (numbering the number of works at only 1,500). In his later life, records by scribes employed at Cambrai specify Dufay as the composer of several large works. See FALLOws, supra note 367, at 75 (describing attributions to Dufay).

374. See Haar, supra note 234, at 136. 
century "the composer" stepped in to fill that role. ${ }^{375}$ Composers such as Josquin des Prez, Adrian Willaert, and Orlando di Lasso (née Lassus) received wide acclaim. The star-maker machinery of the Renaissance music business appears to have operated on positive feedback, giving pyramid shape to the distribution of fame. ${ }^{376}$

The prospect of fame and honor rather than direct financial compensation motivated some composers to seek publication. ${ }^{377}$ The opportunity to win fame and honor also appears to have created the lottery effect that became more intense over time, as some amateur composers financed publication of their work in an effort to win the prize of market success. ${ }^{378}$ Other composers may have held back their compositions so as to keep control over dissemination and to keep the pieces "fresh" for performance. ${ }^{379}$ For similar reasons, patrons also appear to have directed that some compositions remain unpublished. ${ }^{380}$

Publishers marketed their works by advertising the credentials of "the composer" to generate interest in the music, and this practice was perhaps the most significant development that eventually would lead to "the composer" as the legal personality in whom property rights in music would initially vest. ${ }^{381}$ The music-buying public found value in information about the persona associated with a composition, and we might say that composers' names were trademarks, cuing the public in on the source and quality of the work. ${ }^{382}$

375. Id.

376. See, e.g., id. at 137 ("Lasso's praises increased as his fame grew, and as he became the most celebrated musician in all of Europe the praise grew ever more extravagant.").

377. See, e.g., HEARTZ, supra note 228, at 95. For example, Attaingnant published the works of 175 such composers. See id. at 96.

378. As a German theorist lamented:

Moreover, many of those whom I have mentioned even dare to claim for themselves the title of composer. After managing, in the space of half a year, to produce with much sweat a little song, such as it may be, with scarcely three consonances in it, they immediately get it printed, so that their great and glorious name may become known to the whole world. BERNSTEIN, supra note 229, at 99 (translating and quoting PRACTICA MUSICA (1556)).

379. See HEARTZ, supra note 228, at 95 (speculating along these lines).

380. See, e.g., Haar, supra note 234, at 125-26 (identifying Lasso composition withheld from publication at ducal request).

381. See, e.g., BERNSTEIN, supra note 229, at 16 (publishers keenly aware that "books were merchandise to be bought and sold"); HEARTZ, supra note 228, at 90 ("In the complex world of the printing business one easily loses sight of the [person] responsible for there being something to print - the author or composer."). The distinctions between publishers, printers, and booksellers were not sharply drawn in sixteenth century Europe, particularly in the music field. See, e.g., BERNSTEIN, supra note 229, at 10 (describing designation mercatori (merchant) given to leading Venetian publishers, who had economically integrated production and distribution arrangements).

382. See Feldman, supra note 316, at 167 (publishers' claims of authenticity with respect to the identity of composers reflect fact that composers' names "carried capital"). According to Fenlon, "From the 1540s onwards the social connections and employment positions of composers were advertised on title-pages with ever-increasing ingenuity as new commercial attitudes took hold in a growing and increasingly prosperous 
This practice formed part of a more general effort by publishers to build and trade on authors' and composers' reputations, "thus contributing to the celebration of lay culture-heroes and to their achievement of personal celebrity and eponymous fame." 383 With very little legal regulation of attribution practices by either proto-copyright or proto-trademark law, other publishers apparently would trade on this goodwill by falsely attributing works to well-known composers. ${ }^{384}$ To ward off this competition, better-capitalized publishers invested more in editorial services to present the public with a "correct" or "authentic" text. ${ }^{385}$ Presumably, the "correctness" of a text would be judged in relation to the composer's intentions, and demand for a "correct" text signals the increasing authority of the composer in relation to the text. ${ }^{386}$ In the main, it would be premature to cite this development as a recognition of composers' rights in their music. ${ }^{387}$

Not surprisingly, not all composers were treated equally. While emergence of "the composer" as the originator of new and beautiful liturgical and secular music had begun, publishers also developed the role of the journeyman composer, often music editors who composed as a sideline, to assist when either more "functional" musical works were needed or when publishers also needed to fill space in their anthologies. In these cases, the music generally would be published without attribution. ${ }^{388}$

market." FENLON, supra note 215, at 75.

383. Elizabeth Eisenstein, 1 The Printing Press as an Agent of Change: Communications AND CULTURAL TRANSFORMATIONS IN EARLY-MODERN EuROPE 59 (1979).

384. See, e.g., Feldman, supra note 316, at 167 (" $[\mathrm{n}$ a world with no copyright laws and with only limited use of the printing privilege within a restricted number of publishing centers, the bases of ... authenticity claims, like sixteenth-century practices of attribution all told, were highly unstable.”).

385. See FENLON, supra note 215, at 78-79 (describing practice of advertising editorial quality of musical offerings); Ongaro, supra note 311, at 50 (describing why it is plausible that Lasso would have given manuscripts to Scotto's editor, Bonagiunta, for publication); id. at 57 (“The use of self-conscious marketing strategies, the increased role of the professional editor (and the increased public recognition of his or her role), the greater involvement of the composer in the planning stages of a collection, the development of prospective and retrospective anthologies, are all symptoms of this changed attitude, which led the Venetian press towards the industrialization of the late sixteenth century.").

386. See BERNSTEIN, supra note 229, at 108 (describing how "[c]oncern for accurate transmission of their works (and possibly contractual obligations) led to the supervising and proofreading by composers of their music publications"); see also CHANAN, supra note 211, at 115 (music publishing "nurtured the growth of the composer ... [who] became the principal agent not only in the growing complexity of musical language but also in its deepening subjectivity.”).

387. See FENLON, supra note 215, at 79; HeARTZ, supra note 228, at 95 ("[T]he [Renaissance] French composer ordinarily could expect little if any profit from having his work printed and was without protection comparable to a copyright.”).

388. Martha Feldman has examined patterns of attribution and anonymity in published sixteenth-century secular music. She argues anonymous publication correlates positively with the content of the music. Complex or relatively novel five- and six-part madrigals would be the work of attributed composers; whereas shorter madrigals with fewer voices and/or those that relied on melodies or "tune types" associated more closely with 
Interestingly, the composer of music received the accolades while the poets whose words had been used were left largely in the shadows. Renaissance music theorists and composers had come to pay increasing attention to the relationship between music and lyric. ${ }^{389}$ This attention was inspired, in part, by the circulation of ancient Greek theoretical texts. ${ }^{390}$ Within the madrigal form and other types of polyphonic composition, greater attention was given to matching the mood and tempo of the music to the meaning and meter of the words. ${ }^{391}$ For example, the modern popular song finds its roots in the Renaissance. We see it in the Paris chanson and also in the Italian villanelle. ${ }^{392}$ If publishers and consumers of printed music shared the new focus on lyric, one would expect that music publishers would seek to build a public persona around the poet, who rarely was also the composer of the music. In fact, the opposite was true. Composers were featured and many poets were left anonymous. ${ }^{393}$

\section{Precursor to Composer's Copyright}

Focus on textual authenticity and composer control over text motivated the preeminent entrepreneur of copyright in music-Orlando di Lasso. Described as "astonishingly productive," ${ }^{394}$ Lasso appears to have overseen printing of his works in, among other places, Antwerp, Paris, and Venice. ${ }^{395}$ Aware of his own celebrity, Lasso was quite concerned about

folk tradition would be published without attribution. See Feldman, supra note 316, at 171-76 (describing patterns and correlations between attributed and anonymous works).

389. See Fenlon, supra note 210, at 1, 6-7 (describing belief in Renaissance Italy that in Greece poet and composer had been inseparable and how concern with following the wisdom of the ancients caused Renaissance composers to make lyrics more intelligible to pay more attention to composing music that matched the lyrics); BROWN \& STEIN, supra note 207, at 177 (describing increasing importance of matching music and lyric).

390. See BROWN \& STEIN, supra note 207, at 177; see also id. at 331-35 (describing influence of Greek thought on Renaissance composers and theorists); DONALD J. Grout \& HeRMine WeIGEL WILLIAMS, SHORT HistORY OF OPERA, $43-45$ (1988) (describing aesthetic principles embraced by members of the Florentine Camerata, who believed they were recreating ancient Greek and Roman music).

391. See Fenlon, supra note 210, at 8-9.

392. See BROWN \& STEIN, supra note 207, at 205 ("Roughly akin to present-day popular songs, villanelle ... were presumably intended for the enjoyment of a wide spectrum of social classes in the various Italian cities.").

393. See Feldman, supra note 316, at 166-67 (noting that "texts were rarely attributed to their poets in music prints" whereas "both composers and printers generally preferred non-anonymous [musical] works ... because they helped composers' careers to advance and were more commercially viable for printers"); see also $i d$. at 167-68 (citing as evidence of economic value of attribution publishers' practice of filling openings in anthologies with plausibly attributable works in anthologies before turning to anonymous works); BROWN \& STEIN, supra note 207 , at 73 (stating that most of the poems set to music during fifteenth century are unattributable).

394. See BROWN \& STEIN, supra note 207, at 306.

395. See BERNSTEIN, supra note 229, at 108; see generally Haar, supra note 234. For a description of one Venetian editor's claims to have been entrusted with new work of Lasso's while he was in Venice to oversee printing of Duke of Ferrara, see Ongaro, supra note 311, at 50-51 (describing dedications in prints and correspondence by editor/publisher Giulio Bonagiunta Da San Genesi). 
exercising control over the publication of his music. ${ }^{396}$ He complained of finding sloppy or inaccurate reprints of his work, particularly in Germany, ${ }^{397}$ and of the difficulty in identifying errors because of the partbook format. ${ }^{398}$

Exploiting his close connections with the French and German courts, Lasso took the unprecedented step of seeking-and receiving-legal control over his entire body of work. ${ }^{399}$ In a visit to France in 1571, Lasso received the exclusive right throughout France to have printed by whatever firm he chose all existing and future work. ${ }^{400}$ In 1581, Lasso requested and received from Emperor Rudolph II a similarly sweeping privilege to all his compositions, whether previously published or not, throughout the German territories, with no limit on the duration of the privilege. ${ }^{401}$ In a petition that anticipates the arguments for authors' rights, ${ }^{402}$ Lasso expressed concern about exercising quality control for both the benefit of the public and his own reputation. In Haar's paraphrase, Lasso further argued that " $[t]$ o protect his work, in which he has invested his life's blood[,] ... he asks that instead of granting further privileges to printers who handle his work, he, the composer, be granted the privilege, on the basis of which he can then choose publishers and thus control the printing and reprinting of his music." 403 Lasso set a noteworthy precedent in two respects: (1) he was the first composer to obtain a legal monopoly over publication of his entire body of work and (2) he successfully pursued international publication and legal control over his music across political domains. ${ }^{404}$

\section{Performers}

We have seen that, during the Renaissance, Lasso and other composers

396. See Haar, supra note 234, at 140-41

397. See id. at 141.

398. See id.

399. See $i d$. at 135, 141-42 (describing extraordinary privileges).

400. See id. at 135; BERNSTEIN, supra note 229, at 109. This privilege, confirmed in 1575 , had a ten-year term and was renewed for another ten years in 1582. See Haar, supra note 234, at 135. (The choice of printer was a somewhat illusory power as Lasso had longstanding exclusive dealings with the King's printers, Le Roy and Ballard, and the Lasso privilege gave them a de facto monopoly on the printing of Lasso's repertory. See id. at $134-36$ (describing relationship).)

401. See BERNSTEIN, supra note 229, at 109 (describing uniqueness of the Lasso privilege).

402. See Haar, supra note 234, at 141; BERNSTEIN, supra note 229, at 108-09.

403. Haar, supra note 234, at 141.

404. BERNSTEIN, supra note 229, at 109 (Lasso was "the first composer to acquire what might be considered a quasi-international copyright for the publication of all his music."); Haar, supra note 234, at 135 (“[N]o composer before Lasso had ever obtained this kind of personal privilege in France."); id. at 141-42 ("It seems fair to say that Lasso was the first composer to pursue an active international publishing career and to win wide recognition, at the highest official levels, for his efforts."). 
enjoyed new-found notoriety while poets who composed lyrics to popular madrigals and chansons either were previously famous - as was the case with Petrarch—or labored in relative obscurity. In the modern popular music business performers generally often overshadow songwriters and lyricists, so we might inquire as to how professional singers and instrumentalists were viewed during the period.

The record reflects that talented musicians did receive some notice and were also caught up in the competition among political centers. According to Edward Lowinsky, vocal and instrumental performers claimed a share of the freedom from medieval strictures that composers had begun to assert, leading to increased virtuosity in performance. ${ }^{405}$ In his words, "It is safe to make two statements in this connection: the virtuoso is a Renaissance phenomenon; the virtuosoprecedes virtuoso music." 406 But the competition among Renaissance courts for performing talent apparently was less intense than it was for composers (recall that composers also were singers and/or instrumentalists). ${ }^{407}$ Professional musicians generally had three likely employers: a royal patron, a town guild, or the road (i.e., the market for itinerant musicians).

Within the growing urban centers, the religious choirs and musicians' guilds still exercised legal control over public performance within the city, supplying instrumentalists and vocalists for musical performance. ${ }^{408}$ Guild members apparently used their monopoly power to extract a larger share of their patrons' wealth. ${ }^{409}$ Competition to join the guilds remained intense, and membership in at least some guilds demonstrably was based on merit rather than political connections. ${ }^{410}$ Guild members had been

405. See Lowinsky, supra note 130, at 552.

406. See id.

407. See id. (naming some famous poet-musicians but stating that details of performers' careers, performances, and repertories largely unavailable to modern historians).

408. See, e.g., Fenlon, supra note 210, at 27 (discussing employment by Italian courts of professional musicians). For example, the sixteenth-century statutes of Flemish musician guilds describe "a tremendous demand for music for weddings, for dancing, for carnival, for the yearly fair, for processions and a number of other occasions." Lowinsky, supra note 130, at 517. In the city of Antwerp, five town musicians were regularly employed, and they "had to be experts on a great many instruments," Id. at 518. The Flemish town musicians "appeared at all receptions of dignitaries; they played at the colorful processions of the city; on the evenings of holidays they played on the tower of the Cathedral; they were indispensable at all official banquets." Id. at 519. In Italy, "the institution of the town pipers goes back at least to the fourteenth century." Id. In Venice, such "instrumentalists were employed mainly for the many festive processions on the Square of San Marco." Id.

409. For example, in London, at one point in the late 16th century, each wait received a yearly salary of $20 £$, although this high point was short-lived. WOODFILL, supra note 181 , at 37 . The London waits had alternate sources of employment, as well, for they played private concerts. Id. at 40-41 ("The lord mayor, sheriffs, and aldermen habitually called the waits to perform privately for them; the marriage of a daughter was mentioned as an example in the record of their complaint in 1613 that when sent for by the magistrates the waits could not come because of their employment at playhouses. The theatres probably paid better.”).

410. When describing petitions to join the London waits, Woodfill identifies three candidates backed by 
composers during the Middle Ages, and during the Renaissance some members published their compositions. ${ }^{411}$

The politics of prestige in the Renaissance courts also opened greater employment opportunities for musicians, as aristocrats increased their employment of musicians at court at substantial expense. ${ }^{412}$ In some cases competition among groups of professional musicians occurred. ${ }^{413}$

The increased professionalization of secular musicians had its analog in the Church. ${ }^{414}$ Church functions and the music itself were some of the mainstays of Renaissance culture, as they signified much more than they do today. ${ }^{415}$ Where previously Papal singers had subsisted on their incomes from appointments to various parishes, the fifteenth century brought economic reward directly for vocal talent. ${ }^{416}$ Reflecting the importance attached to specialization, the ranks of such singers were opened to non-clergymen who possessed singing talent, at least in

powerful patrons who were refused membership in favor of more accomplished musicians. See id. at 44 .

411. See id. (describing how, among London waits, between three and five members appear to have been published composers).

412. These would be subdivided by trumpeters, wind band of shawms and trombones, the keyboard and string players, who sang secular music, and vocalists for liturgical performance. See William F. Prizer, North Italian Courts, 1460-1540, in THE RENAISSANCE, supra note 209, at 135-36; Freedman, supra note 228, at 177-79 (describing groups of musicians in Francis' court); Picker, supra note 219, at 216-18 (same for Habsburg courts).

413. For example, in London in the mid-fifteenth century, competition among musicians attached to various aristocrats, including the king, and guild members led to a commission of enquiry and subsequent litigation. See RAYNOR, supra note 130, at 66. In a different case in 1558, Jewish musicians formed a guild (klezmorim) and subsequently, over the fierce objections of the city's Christian guild, won the right to perform at Christian weddings. See Gerben Zaagsma, The Klezmorim of Prague, in Groniek. Historisch Tijdschrift 143/32 223-230 (1998) (Dutch), available at http://www.klezmershack.com/articles/zaagsma.prague.html\#12body (English) (last modified Feb. 5, 2003).

414. For example, the Papal Choir moved away from being a collection of clerics toward a specialized choir in which vocal talent was the primary criterion for membership. In 1442, the Papal Choir had ten singers; by 1483 , "their number had increased to 24 , in the years following and throughout the sixteenth century the membership fluctuated, rising at times to 30 singers, but holding usually more closely to 24 , which number came to be regarded as the ideal size for the Papal Choir." Lowinsky, supra note 130, at 510-11.

415. See id. at 512 ("No expenses were spared for composers, singers, and instrumentalists for the celebration of the high holidays, especially Easter."); see also id. at 512-13 (“On important political occasions, at receptions of foreign dignitaries, the celebration of a solemn Mass was inevitable; a Te Deum would invariably be sung after a victorious battle, at the conclusion of a treaty, at the joyous occasion of the arrival of a royal heir; during wartime a Da pacem Domine in diebus nostris would be sung in solemn procession.").

416. "Pope Eugenius IV created the economic foundation for the Papal Choir with his bull Et si erga of 1444 in which the income of the singers from benefices, prebends and canonries, as distinguished from their monthly salaries, was stabilized." Id. at 511 (emphasis added). This did not diminish the appointment of Papal singers to other offices; in fact, they "were to be preferred in their claims on such ecclesiastical benefices to any other claimants." Id.

Nonetheless, the salaries based strictly on singing seem not to be insignificant: "[u]nder Pope Nicholas V (1447-55) their salary was increased from 5 to 8 ducats monthly[, and u]nder every new incoming Pope the privileges of the Papal singers were confirmed in a new bull and substantial amplifications were added." Id. There was a price to hold such a dignified position: "Under Innocent VIII (1484-92) certain provisions were made[:] . . . a Papal singer shall not keep a concubine, he shall not frequent taverns and other inhonesta loca, he shall always appear in his choir gown, and he shall not wear his hair down to the neck." Id. 
Antwerp. ${ }^{417}$ Not all members of the Church supported the increased professionalization of liturgical music, and tensions arose between factions that accepted a porous border between secular and religious musical practice and those who opposed any intermingling of the two. ${ }^{418}$

\section{Summary}

Consistent with the conventional telling of copyright history, music publishers were the first to make distinct property claims that satisfy the criteria for our inquiry. Publishers, in their petitions to political authorities, claimed proprietary relation to the music they had printed or proposed to print and claimed a right or need to prohibit others from competing directly with their respective repertories. The law recognized and vindicated these claims in the privileges granted to the publishers. According to the conventional telling, publishers' claims for proprietary control over the intangible works embodied in their published musical texts derive from publishers' economic insecurity, as they faced indeterminate demand for specific works and significant production and distribution costs that required cross-subsidization by successful titles for unprofitable titles. Unauthorized reproduction of successful titles would undermine publishers' ability to cross-subsidize. These remain economic issues that supply the rationale for modern copyright law. Similarly, early music publishers pursued strategies of collusion and integration to minimize risk and maximize profitability just as modern publishers pursue similar strategies within the bounds of modern competition law.

But in the music business the publishers, as compilers of anthologies,

417. "In an edict of 1410, Pope John XXIII granted the chapter's request to have the revenues of 12 prebends reserved for singers and the distribution made solely on the basis of musical merit." Id. This made possible "the engagement of lay singers, whereas previously singers could be selected from the ranks of priests only. It means, in other words, the admission of the professional musician into the church service. Needless to say, this gave rise to a great improvement in the musical services." Id. at 511-512.

The improvement in the music of the Antwerp Cathedral led to an increase in the number of singers employed, up to 69 in 1549. Id. at 512. And "[t]he increase in the number of singers was accompanied by an increase in salaries, privileges, gratuities, in brief, by a steady rise in the economic and social position of the singers in Rome and Antwerp." Id.

418. Strict conservatives hated musical instruments being played in church, and "tambourines in the performance of a solemn Mass reveal a secular gaiety invading the sacred sphere that- together with the practice of basing a polyphonic Mass on worldly ditties — goes a long way in explaining the increasingly bitter complaints about the profanation of church music throughout the sixteenth century which culminated in the strictures and regulations of the Council of Trent." Id. at 513. The "immense enthusiasm for music at all levels of Renaissance society [was] matched by an intense fear and violent condemnation of the seductive power of the ethereal art." Id. at 528. In fact, blood ran so high that Hieronymus Bosch "placed musicians, musical instruments, and choirbooks in the inferno in several of his hell paintings," and [everyone's favorite Florentine] Savonarola "preaching in music[-]loving Florence, fulminated against the 'suoni e canti,' and on the pyre of 'Vanities' lit by his followers during the carnival season 1497 and 1498 there were lutes and music books." Id. 
also played an authorial role_fulfilled an "author-function," if you will. ${ }^{419}$ Indeed, Scotto and Gardano reasonably could be given credit for developing the "black note" madrigal—so-called because they used faster note values (requiring greater vocal dexterity). This fledgling repertory was more readily available to new entrants in the publishing business. ${ }^{420}$ Attaingnant also played a formative role in the creation of the Paris chanson by selecting predominantly Parisian composers and fanning the market for their musical innovations. ${ }^{421}$ Similarly, as self-conscious compiler, the publisher presented a point of view about a theme or about the present, past, or future through the selection of material. ${ }^{422}$ The authorial aspect of the publishers' relation to their respective repertories should not be overstated, for their proprietary claims did arise primarily from their economic interests in restricting competition. But the standard characterization of the first copyright legislation as effectively turning the law from a distributors' rights regime into one of authors' rights overlooks, at least in the music context, the authorial contributions made by publishers.

The art of music composition also flourished during the Renaissance period. Competition among the courts was channeled in part into arts funding, and composers enjoyed a new kind of star status as they traveled the continent to perform their latest offerings. Music publishers fueled the fires of composers' fame as a means of better selling printed music. With greater resources available and with greater rewards for musical innovation, successful composers increasingly began to conceive of themselves as artists rather than artisans. The law did not respond directly to this development, as royal privileges continued to be granted to those who financed publication rather than those who supplied the musical compositions. However, the case of Orlando di Lasso, who received privilege protection in his capacity as a composer, presages developments in copyright law.

Musicianship also developed as an art during the period. Increasing

419. See Feldman, supra note 316, at 169 ("[O]nce publishing became a boom industry in Venice, publishers gained an authoritative, quasi-authorial power in fashioning and broadcasting the composer's voice."); see generally Michel Foucault, What Is An Author?, in CONTEMPORARY LITERARY CRITICISM: LITERARY AND Cultural Studies 341, 341-353 (Robert Con Davis \& Ronald Scheifer eds., 3d ed. 1994) (offering "authorfunction" as new understanding of authorship to focus attention on the role of readers in constructing social meanings associated with literary texts).

420. See Feldman, supra note 316, at 170 (describing how Gardano built a market for the new style using mostly unattributed works, successfully then luring "name" composers to the genre).

421. See BROWN \& STEIN, supra note 207, at 191.

422. See, e.g., Ongaro, supra note 311, at 44-46 (describing development in 1560s of market for thematic anthologies). Sometimes this authorial role was performed by the publisher's editor. See, e.g., id. at 55-56 (describing second commemorative anthology printed in Venice, compiled by Scotto's editor, Bonagiunta, who claims an authorial role in the compilation). 
expectations that musicians would be musically literate and able to play new and more complex music with little preparation further solidified the social position of professional musicians, a development that had started with the establishment of medieval musicians' guilds.

\section{LESSONS LEARNED FROM THE DEVELOPMENT OF PROPERTY RIGHTS IN MUSIC}

This part summarizes some of the more interesting findings from the history of music's commodification and then offers some lessons for those of us engaged in the debate about the future of music. Neither list is intended as exhaustive, and my hope is that the findings will inspire other insights as well.

\section{A. Summary of Findings}

\section{Ancient Greece and Rome}

The most interesting finding from the ancient world is how different music's role was in a society that had otherwise familiar means of communicating artistic and intellectual thought in writing. Many intellectuals in the United States and Western Europe consider the ancient Greeks to be our intellectual forbears. In institutions of higher learning on both sides of the Atlantic, students in the liberal arts still must engage with Aristotle and Plato, for example, on fundamental questions of how to define the good life for individuals and for the societies in which they live because the thoughts of these ancient thinkers still have relevance. We also continue to study their poetry and to study and perform the tragedies and comedies that these peoples enjoyed. By expressing their thoughts in tangible form, these ancient writers have achieved the closest thing to immortality that is humanly possible.

What of their composers? Where is their music? Lost. Gone with the wind. For music was not rendered in musical scores even though musicians had access to tools for such objectification-a notation system and papyrus. Why did the artistic and intellectual elite, who invested so much energy into written expression of philosophy, science, and visual and dramatic art, not use those tools to express the music that infused their lives? Because we have scripts from the Greek dramatists, the answer cannot be simply that music was a performing art. Even more telling, these very dramatists saw no reason to embody the musical portions of their dramas, music that some, such as Sophocles and Aristophanes, 
apparently composed. ${ }^{423}$ Nor can the answer be that the ancients were indifferent to music because we know from their writings and practices that they regarded music as centrally important, an art that the young were required to learn. ${ }^{424}$

The distance in time makes any answer uncertain, but it appears as if music was written for archival or other purposes and not as a means of enabling performance or establishing an orthodox version of a particular composition. Written music described the modes, the tools for performance. The writings relied on substantial background knowledge of the performers. We can infer that ancient audiences did not relate to the music they heard as distinct compositions but rather as variations on familiar themes, themes that became familiar by repetition and which could be expressed in multiple combinations and permutations. Similarly, even though musical contest winners attained a kind of star status within ancient Greece and Rome, we infer that they did so because of their skill at manipulating the traditional musical melodies in interesting and pleasing ways. For in this world, music was regulated through control over musical labor. And that control was quite strong, as most musical laborers were themselves treated as property. ${ }^{425}$

Thus, from the very beginning of what often in the United States and Western Europe is deemed to be our dominant history, we see the development of property in music as distinct from the development of what would later become literary property. In the ancient world, we see three of the essential elements for modern property claims in intellectual creations with regard to literature: (1) a written language in which thought can be objectified; (2) objectified thought in the form of manuscripts; and (3) authors, the creators (or at least spokespersons) of those thoughts who potentially could claim rights in the objectified versions of their thoughts. We even see the development of trade in manuscripts in which some property rights in at least the tangible objects must have been present. With music we find only the first element, a musical language, and even its capacity to objectify musical expression was limited by extensive reliance on a background oral tradition. We do not find distinct musical works that can be the subject of property rights nor do we have the concept of a musical composer who might have the capacity to assert such rights.

\footnotetext{
423. See supra notes 87,91 and accompanying text

424. See supra note 93 and accompanying text.

425. See supra note 77 and accompanying text.
} 


\section{The Middle Ages}

In the more than one-thousand-year interval between the fall of the Roman Empire and the Renaissance, the three most important developments leading toward commodification of music were: (1) the (re)development of musical notation; (2) the emergence of musical composition as a distinct activity; and (3) the legal vindication of the city guilds' claims for exclusive musical performance rights.

The development of musical notation is a fascinating story. Notation is a tool for either describing or prescribing musical performance. Notation also may have been the means for rendering music as a literary work. ${ }^{426}$ Musical notation developed not in response to demands internal to the development of music as an art form but as a means to exercise better control over liturgical practices. The propagandistic power of music has been recognized by political and religious authorities throughout the period studied. Church authorities pressed for notation to better identify and transmit the centrally sanctioned texts to which the faithful were to adhere. To fulfill that objective, those involved in religious musical practice further enhanced the prescriptive capacity of musical notation. In so doing, they created a system that freed early composers' minds to explore more complex polyphonic expression. The prescriptive power of notation in the hands of individual composers in northern France was too intriguing for them to resist, as the Church bade them do.

As the early composers of religious music became increasingly selfaware subjects, so too did the early songwriters-the troubadours and other itinerants. By paying to have their songs transcribed, the troubadours understood themselves to have created distinct compositions of which they were the source, and they expressed a desire to have these creations take on objective form that would permit their preservation even after the composer was gone. ${ }^{427}$ They succeeded in this objective, for compilers in the next century and a half would bring together their works in chansonniers, which survive to this day. ${ }^{428}$

The development of notation that makes musical objects possible and the emergence of composers as potential claimants of legal rights in those objects were necessary developments for modern copyright in music to emerge. We should also note that even though composers did not relate to their compositions as property (with the odd exception), ${ }^{429}$ exclusive legal rights over musical texts were established during the Middle Ages.

I do not argue that music was treated as property in the Middle Ages,

426. See supra note 155 .

427. See supra note 198 and accompanying text.

428. See supra note 199 and accompanying text.

429. See supra note 204 and accompanying text. 
but I do argue that the commodification process preceded the development of music publishing, even though trade in musical texts lagged that in literary texts. For this argument, understand "musical texts" as encompassing more than written music alone. Prior to the resurgence of written music in Europe, musicians themselves were walking repertories. ${ }^{430}$ In the latter Middle Ages, control over the physical person of a performing musician was exercised by the guild system. Prior to the arrival of printing technology, claims of exclusive rights in relation to music were made by guild members against wandering musicians or domestic rivals. As medieval cities began to grow, rules developed under which only guild members had the right to perform within the city walls in most of Western Europe. These were a set of rights belonging to performers rather than composers as such, although some evidence indicates that guild members did compose music. Some evidence suggests that people within the city walls were interested in hearing the latest and greatest that wandering musicians had to offer, but this audience had to attend peasant weddings or festivals outside the city walls in order to be exposed to these new musical influences.

The Middle Ages end with the preconditions for copyright present, or at least emergent, but without the conceptual development of intellectual property in general, and in any case, certainly not in music.

\section{The Renaissance}

With the arrival of the Renaissance, guild control over music performance was relaxed and the new locus of control resided with music publishers. As the Renaissance is the subject of detailed discussion above, only a few general findings are highlighted here. The law and business of music publishing during the Renaissance set the precedent for the modern legal-business-musical complex. As musical literacy increased, the printed text took on a new authority: ${ }^{431}$ the text came to be viewed as a set of directives from composer to performer. ${ }^{432}$ We came to view music as a form of property when the law granted publishers rights to control reproduction of these texts. Property rights in these texts, however, were limited by the scope of royal or municipal patents or privileges. As a practical matter, these were rights held and exercised only against direct competitors.

As between publisher, performer, and composer, the composer has only begun to emerge as a subject capable of making proprietary claims to his

\footnotetext{
430. See supra notes $171-72$ and accompanying text.

431. See CHANAN, supra note 211, at 69-73 (describing development of authoritative score).

432. See id.
} 
or her music. ${ }^{433}$ Most composers of "classical music" were better known as performers, most of their income derived from performance, and it was through performance of their own music that they promoted their compositions. Eventually composers also would become the subject of a narrative embodying Romantic notions of creativity. ${ }^{434}$ The earliest protagonist was Orlando Lassus (di Lasso), who successfully received privileges in France and Burgundy in his capacity as composer to control publication of his music. ${ }^{435}$

\section{B. Lessons From History}

This subpart offers a few observations about how the historical perspective can broaden the discussion about the future of music.

\section{Tools}

As noted above, the preconditions for objectifying and commodifying music were present in the ancient world and were again developed well before the Renaissance. So far as we can tell, however, the notion of property in music had no place in the conceptual cosmologies of the ancient world or the Middle Ages. To understand why this was, we need to balance materialist and idealist understandings of historical development. The presence of the material conditions for commodification did not determine that commodification would follow. Similarly, the flexibility in the concept of private property, which was well understood in the ancient world and the Middle Ages and extended even to intangible property, ${ }^{436}$ did not foreordain that music would be swept within the conceptual domain. Rather, the material conditions surrounding the economics of early music publishing and the conceptual flexibility of the notion of property as expressed in royal privileges were brought together to serve the specific needs of the political authorities and early music publishers.

The explosive growth of the Internet and rapid development of new digital technologies change our material conditions significantly. So far as

433. See, e.g., id. at 115 ("Moreover, [music publishing] not only produced growing standardization in the appearance of the musical script but also nurtured the growth of the composer-in much the same way that the evolution of general publishing nurtured the author-and the composer became the principal agent not only in the growing complexity of musical language but also in its deepening subjectivity.”).

434. For descriptions and critiques of the Romantic view of authorship, see generally THE CONSTRUCTION OF AUTHORSHIP:TEXTUAL APPROPRIATION IN LAW AND LITERATURE (Martha Woodmansee \& Peter Jaszi, eds., 1994).

435. See supra notes $11,376-78$ and accompanying text.

436. See generally VerSteeg, supra note 100. 
we know, the Greeks and Romans did not discuss or question how the presence of papyrus and musical notation made new conceptions of music possible and whether the concept of musical property was desirable. But we can, and we should, ask whether our changed material conditions make possible new concepts of music's social and legal status. Changes in our material conditions are linked to the fundamental Greek insight that music can be represented as a form of code, a mathematically precise form of code. Computers are very good at processing mathematically precise codes. Digital technology makes incremental, intermediate, and fundamental changes in musicmaking possible.

Among the incremental changes are the now-familiar properties by which digital technology greatly reduces the costs of recording, distributing, and storing recorded music. ${ }^{437}$ In addition, digital technology also makes possible new ways to create music. It should not be surprising to learn that computers can "listen" to recorded or live music and analyze and then translate what they "hear" into visual representations in musical notation. This capability means that just as voice recognition software makes possible visual representation of language to the illiterate or those unable to type, music recognition software makes possible the visual representation in prescriptive notation of a musical work sung or played to the computer by a musically illiterate person. Other forms of composition software extend the abilities of amateurs to express themselves in musical notation.

Intermediate changes involve the ease with which digital technology facilitates new combinations of existing musical material-e.g., mash-ups - and collaboration across the Internet. In some of these interactions, the computer serves almost as a co-author of the resulting musical work. This kind of musicmaking strains a property rights' conception of music because the potential claimants in a resulting musical work are many. Administering a property rights system becomes more expensive for such music and may no longer have a comparative advantage in financing musical production and distribution.

Fundamental changes in the way digital technology may affect musicmaking are suggested by computers' ability to "learn" how to compile music $^{438}$ or to compose music. ${ }^{439}$ It should not be too hard to imagine a

437. See, e.g., Mark McClusky, Making Your Bad Tunes Sound Good, WIRED NEws, Jul. 23, 2002, available at http://www.wired.com/news/culture/0,1284,53341,00.html.

438. See, e.g., Katie Dean, DJ Robot Turns the Tables, Wired News, May 28, 2001, available at http://www.wired.com/news/culture/0,1284,43976,00.html (describing computer programmed to act as disc jockey).

439. See, e.g., Karlin Lillington, Singing Is the Rain, WIRED NEwS, Sept. 20, 2000, available at http://www.wired.com/news/culture/0,1284,38850,00.html (describing computer program that associates rainfall data with musical data to compose traditional Irish tunes). Computers also can generate poetry or lyrics. To generate such a poem, visit http://www-cs-students.stanford.edu/ esincoff/poetry/jpoetry.html. 
time when you may be able to tell your computer to play some "dinner music," and the computer will comply with compositions rendered on the fly from a sophisticated database reflecting your tastes and gigabytes of musical samples from which to draw or mimic. Would it make sense to treat such music as property? If so, whose?

We are not yet in that world, or at least most of us are not, and it is not clear that we would prefer computer-generated compositions even if they were in some senses "better" suited to our needs. That is, we have known from ancient times about music's mood-inducing or mood-enhancing properties. If we turn to music for mood-inducement or moodenhancement, computers may well come to be better suited at producing music that achieves the desired effect.

To determine whether the concept of property in music that vests initially with the composer or authors of the sound recording will continue to make sense, we should consider the new possibilities. First we should consider whether we relate, or want to relate, to music as an intersubjective experience shared among composer, performer, and listener, and mediated through the digital object of recorded music, or do we as listeners interrelate with recorded music as object only. Then we should ask whether property in music is the appropriate legal framework to structure that relationship.

As of this writing, intersubjective relations appear essential for at least some sorts of music. With most popular music, the persona of the music's composers and performers plays as important a role in how audiences receive the music now as it did when Renaissance publishers first began touting the credentials of their composers. The same can be said for composer-audience relations with respect to classical music and most jazz. But some forms of instrumental music serve as little more than musical wallpaper, in which the audience's interest is solely in the qualities of the musical object. Consider the commuter with jangled nerves who tunes in the radio station featuring "Smooth Jazz." The commuter may well be indifferent to whether the soothing sounds emanated from Kenny $\mathrm{G}^{440}$ or a Power Mac G5. ${ }^{441}$ For such computer-generated music, property rights will not have induced creation of the specific compositions, although property rights may induce creation of the software that generated the composition.

For the foreseeable future, though, changed material conditions seem unlikely to alter our collective preference for at least some human-composed and human-performed music. Our task, in that case, is to assess whether the changed material conditions presented by digital technology,

440. For composer/performer specifications, see http://www.kennyg.com/ (2002).

441. For product specifications, see http://www.apple.com/powermac/ (2004). 
insofar as human musicmaking goes, are sufficiently significant to cause us to abandon or alter our notions of musical property.

\section{Rules}

The rules embodying and articulating the concept of property rights in music were made to serve specific political and economic objectives, and changed conditions, particularly those that radically alter the economics of music production and distribution, should lead us either to abandon those rules or to revise them to reflect the new economic reality. The protoproperty rules that anticipated copyright served Renaissance music publishers, who faced substantially different economic risks than do those who produce and distribute recorded music today. In relative terms, the costs of reproduction and distribution were substantially higher than today, but the costs of marketing were substantially lower.

The legal rights music publishers received were substantially narrower than those granted under modern copyright law. Publishers could seek recourse only against direct competition in the form of literal reproduction. No claim would lie for derivative use of a composition, nor would the publisher have any rights to control public performance of the composition. Supplementing legal protection was the protection afforded by architecture. A copyist would have to bear substantial copying costs and would be very similarly situated to the initial publisher because that publisher's cost of obtaining the musical work was negligible. The principal difference between the initial publisher and a competitor was that the initial publisher had to cross-subsidize the cost of producing unsuccessful titles with the revenues from successful titles.

Changes in digital technology have drastically reduced the costs of both initial publication and unauthorized republication. We cannot say whether these changes should lead us to increase or decrease the duration or scope of copyright in music without taking a close look at how the changed costs of initial publication and copying affect the incentives for those who produce and distribute music. We should determine whether some form of copyright remains the best way to finance the production and distribution of music. If so, we should not let inertia determine the scope of copyright in music. Instead we should fashion copyright in music suited to our changed conditions.

\section{Liberties}

One of the more striking changes rendered by our modern conception of musical property is legal vindication for an owner's proprietary claims to derivative uses of musical works. Throughout the ages, and certainly in 
the places and period discussed in this Article, musicians have borrowed from the music around them to create new compositions. This historical fact has practical importance in the application of copyright law. Under today's legal regime, is such borrowing an intrusion on another composer's "property"? The idea/expression dichotomy limits the reach of such claims, but implementing that limit in music cases has been particularly difficult. ${ }^{442}$ Music sampling also is a version of this ages-old practice that now is likely to incur legal liability.

One might think that fair use would privilege conduct that has such a long historical pedigree. Frequently it does not. One reason is that the codified fair-use factors ${ }^{443}$ do not take account of traditional practices. On the contrary, under the fourth factor, if the plaintiff can demonstrate its ability to commodify and license what was previously a privileged use, the use is likely to be unfair. ${ }^{444}$ Moreover, at a higher level of generality, the Supreme Court's balm has been as follows: "Perhaps no more precise guide [for applying fair use] can be stated than ... 'Take not from others to such an extent and in such a manner that you would be resentful if they so took from you." 445 This stance might be helpful in order to evaluate fair use if the "resentfulness" standard were stable. However, the norms of artistic resentment often are shaped by law. As copyright owners begin to succeed in commodifying what were once privileged uses, the "resentfulness" baseline shifts ${ }^{446}$ and the scope of fair use shrinks. Consequently, we should ask whether digital technology, which can be used to facilitate traditional borrowing, should lead to a reexamination of the legal treatment of derivative uses of musical works.

\section{CONCLUSION}

Battles over the future of music have been fought throughout Western history. During the period discussed in this Article most of those battles have focused on direct control by political and/or religious authorities over the content of music created and performed in society. Notwith-

442. See, e.g., Bright Tunes Music Corp. v. Harrisongs Music, Ltd., 420 F. Supp. 177 (S.D.N.Y. 1976) (holding George Harrison liable for infringement for unconscious derivative use of pre-existing song). For the unseemly sequel to this litigation, see ABKCO Music, Inc. v. Harrisongs Music, Ltd., 944 F.2d 971 (2d Cir. 1991).

443. See 17 U.S.C. $\$ 107$ (2000) (measuring fair use by (1) purpose and character of use; (2) nature of work; (3) amount and substantiality taken; and (4) effect on the market).

444. See Paul Goldstein, Copyright’s Highway: From Gutenberg to the Celestial Jukebox 7-8 (2003) (story of the Coca-Cola Company).

445. Harper \& Row, Publ'rs v. Nation Enters., 471 U.S. 539, 550 n.3 (1985) (citation omitted).

446. See, e.g., Negitivland, The Public Domain: Two Relationships to a Cultural Public Domain, 66 LAW \& CONTEMP. PROBS. 239, 255-62 (2003) (arguing that creative re-use of popular music should be regarded as fair use). 
standing the occasional congressional hearing about obscene or violent lyrics in popular music, in our society we appear committed to a policy expressed in the First Amendment to maximize the freedom of expression enjoyed by those who compose music.

At our founding we adopted copyright as the engine for that free expression with an understanding about the costs of producing and disseminating printed materials, and we made explicit that this understanding applied to music in 1831. This fundamental economic understanding was rooted in the experience of Renaissance publishers, who faced significantly different economic risks than do modern publishers. Developments in digital technology have again altered the economic landscape to the point that we can meaningfully ask whether the exclusive rights in music provided by copyright law remain the best tool to implement our policy of maximizing musical creativity.

For those engaged in the debates over the future of music, it is important to recognize that music has been part of human culture for as long as humans have been communicating and that the property-rights model for financing music production and distribution is a relatively recent development in response to specific social, political, and economic circumstances. Digital technology alters those circumstances quite substantially, and the law should adapt to account for these changes. 